\title{
Literature Review on the Greenhouse Effect and Global Warming
}

by M. English, R.K.W. Wong and B. Kochtubajda 3

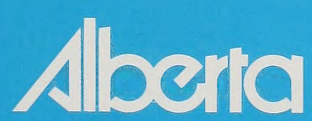

ENVIRONMENT

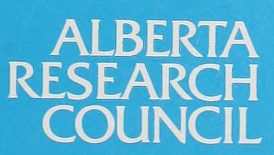

Alboria 
$\begin{array}{ll}\text { National Library } & \begin{array}{l}\text { Bibliothèque national } \\ \text { of Canada Canada }\end{array}\end{array}$ 


\section{Literature Review on the Greenhouse Effect and Global Warming}

by M. English, R.K.W. Wong and B. Kochtubajda

Project Leaders:

M. English, Alberta Research Council H. Petri, AOSTRA Library and Information Services

Prepared for:

Alberta Department of Energy Alberta Department of Environment Alberta Oil Sands Technology and Research Authority Alberta Research Council

Resource Technologies Alberta Research Council AOSTRA Library and Information Services

Edmonton, Alberta, Canada August, 1990 


\section{Acknowledgements}

This project was jointly funded by the Alberta Department of Energy, the Alberta Department of Environment, the Alberta Oil Sands Technology and Research Authority (AOSTRA) and the Alberta Research Council (ARC). The authors wish to thank Ian Burn (Energy), Harby Sandhu (Environment), Ernest Wiggins (AOSTRA), Janet Damery-Smith (Energy) and Helga Petri (AOSTRA Library and Information Services) for their advice and assistance. We gratefully acknowledge the contributions to this study by AOSTRA Library and Information Services staff James Li, Rosa Tsen, Anna Kaplansky, Gene Lau, Roberta Morrison, May Fallis, Rolande O'Hara; Alberta Research Council staff Peter Klivokiotis, Carey Gibson, Lawrence Cheng, Andrew Krol, Bill Korendyk and Sylvia Andrews-Smith; and Alberta Department of Energy staff Barbara Lacroix and Tracey Verlik. 


\section{TABLE OF CONTENTS}

LIST OF FIGURES

EXECUTIVE SUMMARY

1.0 INTRODUCTION 6

2.0 METHODOLOGY 7

2.1 Bibliography 7

2.2 Publications Selected for Review 7

2.3 The Questionnaire

2.4 Analysis of the Questionnaires

3.0 RESULTS

3.1 Computer Modelling of Climate $\quad 9$

3.1.1 Results from the Literature 10 Review

3.2 Monitoring of Greenhouse Gases 12 and Climate

3.2.1 Results from the Literature 12 Review

3.3 Potential Impacts of Climate Change 13

3.3.1 Results from the Literature 14 Review

3.4 Potential Response Strategies 15

3.4.1 Results from the Literature 16 Review

3.5 Technological Solutions 16

3.5.1 Results from the Literature 16 Review

4.0 SUMMARY

5.0 REFERENCES

APPENDIX A:

List of Citations for Papers that were

Reviewed

APPENDIX B:

Sample Questionnaire

APPENDIX C:

Complete Results from the Analysis of the Questionnaires 


\section{List Of Figures}

Figure 3.1 Topics Addressed 9

Figure 3.2 Type of Emissions Addressed 10

Figure 3.3 Time of Effective Doubling of 11 Greenhouse Gases

Figure 3.4 Global Temperature Increase Predicted for an Effective Doubling of Greenhouse Gases

Figure 3.5 Temperature Increase in Northern Latitudes Predicted for an Effective Doubling of Greenhouse Gases

Figure 3.6 Components of the Atmosphere that are Changing

Figure 3.7 Potential Impacts on Agriculture of an Effective Doubling of Greenhouse Gases

Figure 3.8 Potential Impacts on Forestry of 14 an Effective Doubling of Greenhouse Gases

Figure 3.9 Potential Impacts on Health of an Effective Doubling of Greenhouse Gases

Figure 3.10 Suggested Emission Limitation Strategies in Response to Global Warming

Figure 3.11 Suggested Technological Solutions in Response to Global Warming 
The public is concerned about greenhouse gases, global warming, and global climate change, yet there is widespread recognition of the uncertainties concerning the science and impacts of climate change. For this reason, the Alberta Research Council undertook, on behalf of the Alberta Department of Energy, the Alberta Department of Environment, the Alberta Oil Sands Technology and Research Authority and the Alberta Research Council, to conduct a literature review of recent (from 1988, 1989, 1990) publications to provide an overview of the degree of consensus on the science of global warming and climate change.

The objectives of the project were to:

1) develop a listing of relevant citations (bibliography) for the period 1980 to 1990

2) review the publication's from 1988, 1989 and 1990 , prepare a short summary of the content of each, and develop statistics with respect to the degree to which scientific consensus exists on the various topics of interest.

The bibliography which was developed (Petri, 1990) contains 1557 citations.

A total of 501 publications were reviewed. Publications from known opponents of the global warming issue were specifically included. For each publication reviewed, a questionnaire which addresses the key concerns of government and industry was completed and the questionnaires were analyzed to produce the statistics that show the degree to which scientific consensus exists on the various topics. The topics of interest are computer modelling of world climate, monitoring of the atmosphere and climate, potential impacts of climate change, potential strategies for responding to climate change, and technological solutions.

Both the bibliography and reviewed papers have been computerized and online searches can be tailored to individual needs. Hard copies of the reviewed papers are available as well. For access, the AOSTRA Library and Information Services should be contacted.

The results show that, with respect to modelling climate and monitoring the atmosphere and climate, a strong consensus exists within the scientific community and those who interpret science, on the magnitude, timing and cause of potential climate change. Strong consensus also exits with respect to some potential impacts, strategies and solutions, especially on a global scale.
Although substantial numbers of papers address the major topics, the review also indicates that the number of papers that deal with important subsets (such as expected climate changes or impacts within a specific region) is quite small.

With respect to Alberta, an increase in average annual temperature of about $5^{\circ} \mathrm{C}$, a modest overall increase in total annual precipitation with increases or decreases in specific regions and seasons, and both positive and negative impacts are anticipated by about 2050 . 


\subsection{INTRODUCTION}

Greenhouse gases and the potential for global climate change are receiving increased attention by individual countries and in international forums. Many of the options for responding to concerns about global climate change have very significant implications for the production and use of various forms of energy.

At the same time, other air quality issues such as the depletion of the ozone layer, acid deposition, smog, etc. are receiving attention at the international, national and regional levels.

In response to public concern about these issues, the Alberta government has announced the Clean Air Strategy for Alberta initiative, which is jointly managed by the Alberta Department of Energy and the Alberta Department of Environment. Its purpose is to encourage public discussion in Alberta on emissions into the air resulting from the production and use of energy, to help identify and clarify the possible impact of energy-related emissions on the environment and to identify practical and achievable actions that can be taken by producers and consumers to reduce emissions. The Clean Air Strategy for Alberta initiative is to result in a comprehensive, integrated approach to addressing air quality problems in Alberta.

While there is public concern over greenhouse gases, global warming, and global climate change, there is also widespread recognition of the uncertainties concerning the science and impacts of climate change. It is important to the success of the Clean Air Strategy for Alberta that these uncertainties be clarified as much as possible and the information be made available to all who participate.

For this reason, the Alberta Research Council has undertaken, on behalf of the Alberta Department of Energy, the Alberta Department of Environment, the Alberta Oil Sands Technology and Research Authority and the Alberta Research Council, a literature review of recent publications (from 1988, 1989 and 1990) to provide an overview of the degree of consensus on the science of global warming and climate change.
A thorough, scientific review of the timing and magnitude of anticipated global warming has been carried out by the Intergovernmental Panel on Climate Change (IPCC) on behalf of the World Meteorological Organization and the United Nations Environment Program. Their findings were presented to the 2nd World Climate Conference, Geneva, Switzerland in November, 1990. The Alberta Research Council did not attempt to duplicate the efforts of the IPCC. Rather, the Alberta Research Council study documents the diversity of views and the degree of consensus on the various issues related to global warming.

In conducting the literature review, an annotated bibliography was produced (Petri, 1990) along with a summary of the contents of the publications reviewed. The summary is based on a series of questions that were answered for each publication. The project was managed jointly by the four sponsoring organizations.

The methodology used to carry out the literature review, including the criteria used to select the publications, a description of the questionnaire developed to identify and summarize the issues and current scientific consensus, and a description of the analysis performed to quantify the results of the questionnaire, is presented in Section 2. The results from the questionnaire analysis are discussed in Section 3. A summary of the scientific consensus on global warming and climate change emerging from this literature review is presented in Section 4. 


\subsection{METHODOLOGY}

The objectives of the project are to:

1) develop a listing of relevant citations (bibliography) for the period 1980 to 1990 ;

2) review publications from 1988, 1989 and 1990, prepare a short summary of the content of each, and develop statistics with respect to the degree to which scientific consensus exists on the various topics of interest.

\subsection{Bibliography}

The bibliography was developed using references from the Draft Report to Congress of the United States Environmental Protection Agency (EPA, 1989) and the Canadian Climate Centre's listing of citations (relevant to carbon dioxide and other greenhouse gases) as a base. Additional citations were found through library searches of the United States Department of Energy data base.

Originally, it was intended that other data bases be searched as well, however, this was not possible within the available resources.

To ensure some minimum quality in the publications included in the bibliography, only publications from reviewed scientific journals and official government publications were included for the years 1980 to 1988 . For the years 1989 and 1990 , this requirement was relaxed so that a more comprehensive bibliography could be established for that period. Efforts were made to include publications by known opponents of the global warming issue.

The bibliography was limited to publications that address the key issues of concern to Alberta government officials and industry representatives. These issues are: climate modelling, monitoring of the atmosphere and the climate, potential impacts of climate change, potential strategies for responding to climate change, and technological solutions to the problems created by climate change.

The resulting bibliography is given in Petri (1990) and contains 1557 entries.

\subsection{Publications Selected for Review}

Publications listed in the bibliography for 1988 , 1989,1990 were reviewed. Short summaries of their contents were prepared. As well, a questionnaire to address the key concerns of government and industry was completed for each. The questionnaires were then analyzed to produce the statistics that show the degree to which scientific consensus exists on the various topics. A listing of the papers reviewed is Appendix A.

Considerable difficulty was experienced in obtaining publications which are not readily available in Alberta. The period between ordering and receiving a publication, in general, was much longer than anticipated. In fact, more than 100 publications ordered early in the study were not received. Furthermore, many publications identified through library searches were found to be not relevant to the key concerns. For example, many deal with methodology without giving any results that are relevant to the questionnaire. As well, obtaining hard copy of publications through library searches was more expensive than anticipated.

\subsection{The Questionnaire}

A survey questionnaire was developed as a means to provide government officials and industry representatives with an overview of the issues and current scientific consensus that is emerging on global warming and climate change. The questionnaire summarizes information obtained from an extensive literature review. The review only considered contributions from recent (1988-1990) publications including reviewed scientific journals, official government reports, technical reports, and articles from general interest publications, or conference proceedings (see Appendix A).

Questions were formulated in cooperation with the project sponsors. The specific objectives and emerging scientific consensus related to:

a) computer modelling of world climate;

b) monitoring and/or observations of the atmosphere or the climate;

c) the potential impacts of climate change;

d) potential strategies for responding to climate change; and

e) technological solutions. 
A sample questionnaire is Appendix B.

The questionnaire is divided into five sections. In the first, the type of publication and the issue(s) addressed are identified. Review papers are identified separately and all the issues covered in the review noted.

In the second section, questions concerning climate modelling are formulated to address the type of emissions, when an effective doubling of greenhouse gases is expected to occur, the predictions (expected for a doubling of greenhouse gases) of future annual temperature and precipitation changes on the global, northern latitude and Alberta climates, and the changes in weather extremes, if any.

The third section addresses the issue of changes in the atmosphere. Specifically, what components are changing? What are the global instrumented observations of temperature and precipitation variations over the past century and decade suggesting? What are the causes of these changes?

In the fourth section, a qualitative assessment of the potential impacts of climate change on various sectors is carried out. These impacts are assessed from a global, Canadian, Prairie, and Alberta perspective.

In the last section of the questionnaire, potential strategies and technological solutions to respond to the threat of potential climate change are identified.

The questionnaire is restrictive in a sense. Although the questions are designed to answer specific needs, there are situations where a paper could be useful without answering the specific questions posed. For example, a modelling paper assessing the cloud feedback effect could imply that many climate models overestimate greenhouse warming. Such results are relevant to the general question of whether there is a greenhouse warming problem, but fail to fit the questions on the questionnaire.

\subsection{Analysis of the Questionnaires}

The basic analysis of the completed questionnaires considers counts of the various responses. The data base derived from the questionnaires is divided into six categories and the same analysis applied to each of the categories. The categories are:

1) all papers that were reviewed (501 questionnaires)

2) refereed scientific papers only (205 questionnaires)

3) review-type papers only (119 questionnaires)

4) non-review-type papers (382 questionnaires)

5) refereed review-type papers (54 questionnaires)

6) refereed non-review-type papers (151 questionnaires).

One reason for subdividing the papers reviewed was to assess the quality of the results given in the papers. Publications which appear in established scientific journals are generally subjected to peer review prior to publication. This means that they are reviewed by a number of other experts in the field to ensure that no obvious errors were made in obtaining the published results. Such peer-reviewed publications are said to be "Refereed" papers. Categories 2, 5 and 6 contain only these types of publications.

Categories 3 and 4 represent results obtained through a review of research conducted by others. This amounts to a second generation analysis. Such articles are identified as "Review-Type" articles and all others are classified as

"Non-Review-Type" articles.

Results of the analysis from the subsets of papers are tabulated in Appendix C. 


\subsection{RESULTS}

The number of papers that address the various topics of interest are shown in Figure 3.1. Note that a substantial number -- 119 is the minimum -- address each topic. The greatest number of papers deals with the potential impact of climate change.

\section{Topics Addressed}

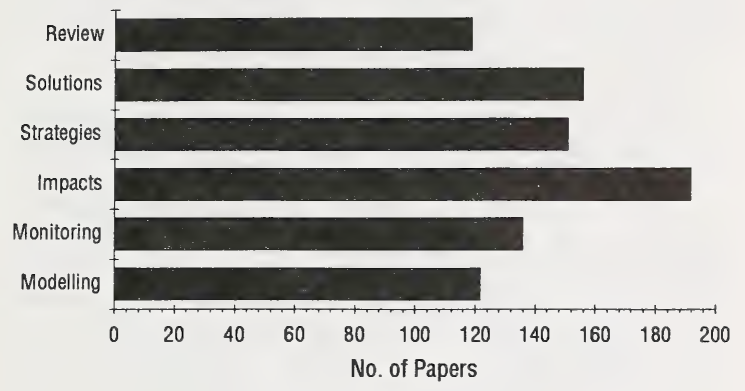

Figure 3.1 Number of papers that address various topics of interest. The topics are: computer modelling of climate, monitoring of the atmosphere and climate, potential impacts of global warming, potential response strategies to global warming, potential technological solutions and a review of the global warming issue.

\subsection{Computer Modelling of Climate}

There is concern that human activities may be inadvertently changing the climate of the earth and much effort has been devoted to developing computer models that can predict the earth's climate for some future state of the earth/ atmosphere system.

The driving energy for weather and climate comes from the sun. The sun's rays pass through the atmosphere and are absorbed by the earth's surface, which heats up and radiates energy back into space. Some of the gases in the atmosphere capture and hold radiated energy, keeping the surface of the earth warm, much as the glass of a greenhouse keeps the plants inside warm.

Without the greenhouse gases such as carbon dioxide $\left(\mathrm{CO}_{2}\right)$, all radiated heat would be lost into space and the surface of the earth would be much colder.
The main natural greenhouse gases are not the major constituents of the atmosphere (nitrogen and oxygen) but are water vapour (the greatest contributor), carbon dioxide, methane, nitrous oxide and ozone. By increasing the concentrations of these greenhouse gases and by adding new greenhouse gases like chlorofluorocarbons (CFCs), humankind is capable of raising the earth's temperature. Strictly speaking, this is an enhanced greenhouse effect -- above that occurring due to natural greenhouse gas concentrations.

Changes in solar output, in the earth's orbit, in composition of the atmosphere, and in the surface of the earth are factors which can change the amount of radiation that is emitted to space by the earth/atmosphere system and so change the temperature of the earth's atmosphere and surface.

A change in the earth's surface due to deforestation or desertification affects the amount of solar energy absorbed at the earth's surface. For instance, deforestation has several potential impacts on climate: through the carbon and nitrogen cycles (where deforestation can lead to changes in atmospheric carbon dioxide concentrations), through the change in reflectivity of terrain when forests are cleared, through its effect on the hydrological cycle (precipitation, evaporation and runoff) and surface roughness and thus atmospheric circulation which can produce remote effects on climate. Human-made dust particles, from sulphur emitted largely in fossil fuel combustion, can modify clouds which may affect the earth's temperature. Changes in ozone in the stratosphere due to CFCs may also influence climate.

Water vapour has the largest greenhouse effect, but its concentration in the atmosphere is determined internally within the climate system, and, on a global scale, is not affected by human activities. Water vapour will increase in response to the global warming and further enhance it.

Some greenhouse gases are potentially more effective at changing climate than others. Carbon dioxide is the least effective greenhouse gas per kilogram emitted, but because of the large amounts already in the atmosphere as well as those being emitted daily, it is the greenhouse gas that currently contributes most to global warming. 
For a thousand years prior to the industrial revolution, the concentrations of greenhouse gases were relatively constant. However, as the world's population increased and it became more industrialized, and as agriculture developed, the concentrations of greenhouse gases increased markedly. To estimate future climate change, we need to know future greenhouse gas

concentrations. These concentrations depend upon the magnitude of human-made emissions and on the exchange of greenhouse gases between the atmosphere, oceans and the earth's ecosystems.

For simplicity, anticipated concentrations of the greenhouse gases are usually expressed in terms of the "Equivalent Carbon Dioxide Concentration" so that the effect on climate is more readily estimated. For each gas the "equivalent carbon dioxide concentration" takes into account its relative effectiveness as a greenhouse gas and the time the gas remains in the atmosphere. Greenhouse gases have increased since pre-industrial times (1765) by an amount equivalent to about a 50 per cent increase in carbon dioxide, although carbon dioxide itself has risen by only 26 per cent.

The best tools currently available for estimating the effect on the earth's climate of increased concentrations of greenhouse gases in the atmosphere are three-dimensional mathematical models of the climate system (atmosphereocean-ice-land), known as General Circulation Models (GCMs). GCMs synthesize our knowledge of the physical and dynamical processes in the overall system and allow for the complex interactions between the main components. However, in their current state of development, the descriptions of many of the processes involved are relatively crude. Because of this, considerable uncertainty is attached to the predictions of climate change, which is reflected in the range of values given.

Predictions of future climates are usually expressed in terms of the climate anticipated when the total concentration of all greenhouse gases in the atmosphere is equivalent to a doubling of the pre-industrial (1765) concentration of carbon dioxide.
Global warming may also lead to increased global average precipitation and evaporation. Areas of sea, ice and snow are expected to diminish. Knowledge of the global mean warming and change in precipitation is of limited use in determining the impacts of climate change. For this we need to know changes regionally and seasonally. GCMs cannot yet give reliable regional predictions at the smaller scales demanded for impacts assessments. Changes in the variability of weather and the frequency of extremes will generally have more impact than changes in the mean climate at a particular location.

\subsubsection{Results from the Literature Review}

Figure 3.2 shows the type of emissions addressed by the publications; the greatest number deal with carbon dioxide emissions. As well, a substantial number of papers address greenhouse gases in general.

\section{Types Of Emissions Addressed}

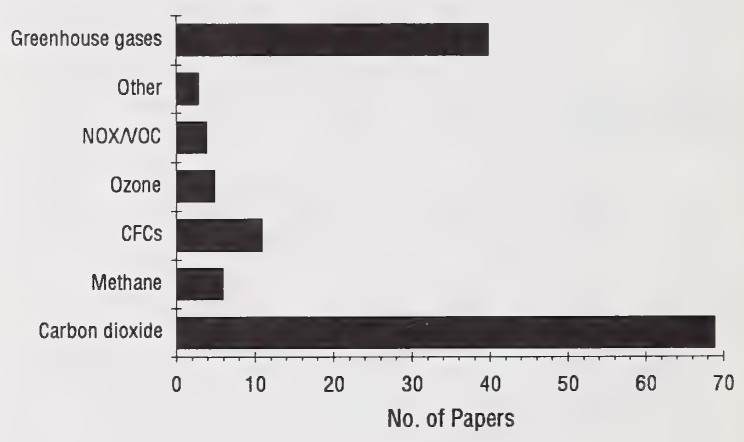

Figure 3.2 Number of papers that address the various types of emissions: emissions of carbon dioxide, of methane, of chlorofluorocarbons (CFCs), of ozone, of nitrogen oxides and volatile organic compounds (NOx/VOC), of other types of emissions (dust particles) and of unspecified greenhouse gas emissions.

With respect to the occurrence of greenhouse gas concentrations equivalent to a doubling of the pre-industrial concentration of carbon dioxide, most publications suggest that this will occur about 2050 (Figure 3.3). It is significant that no publication suggests the effective doubling of pre-industrial carbon dioxide (referred to henceforth as "effective doubling of greenhouse gases") may never occur. 
Time Of Effective Doubling Of Greenhouse Gases

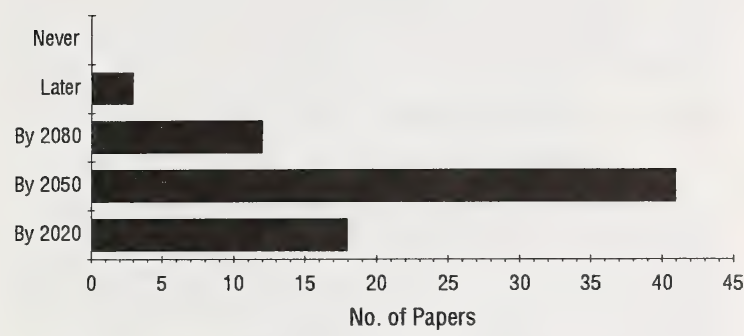

Figure 3.3 Number of papers that suggest that the concentration of greenhouse gases in the atmosphere will be equivalent to a doubling of pre-industrial carbon dioxide by various dates.

With respect to the increase in global temperature anticipated from an effective doubling of greenhouse gases, Figure 3.4 indicates that most of the publications suggest that this increase will be in the range of 3 to $3.9^{\circ} \mathrm{C}$. This is in agreement with the results announced recently from the Canadian Climate Centre General Circulation Model (Hengeveld, 1990).

\section{Global Temperature Increase Predicted For An Effective Doubling Of Greenhouse Gases}

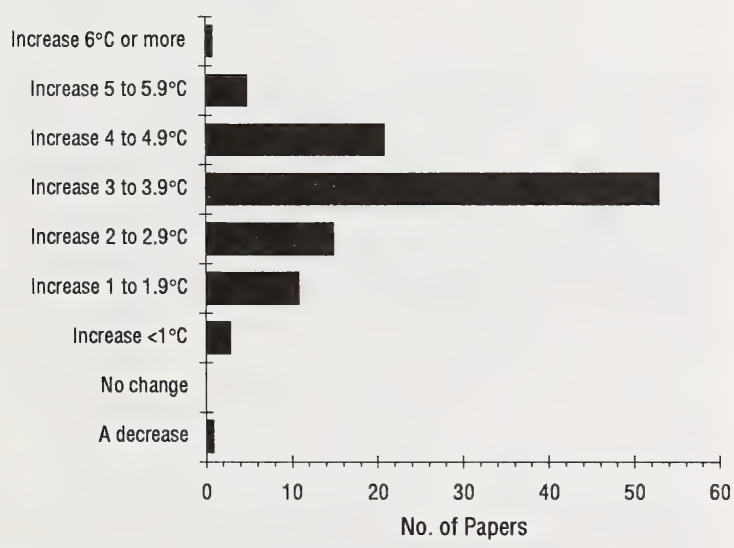

Figure 3.4 Number of papers that suggest the increase in global temperature will be of stated magnitude when the greenhouse gas concentration in the atmosphere becomes equivalent to a doubling of the pre-industrial concentration of carbon dioxide.
Results given in Appendix $\mathrm{C}$ show that the refereed, non-review type articles (i.e. the original scientific research) produce a broader spectrum of opinion both with respect to the time and the magnitude of the temperature increase of an effective doubling of greenhouse gases. This is not surprising because a review article might focus on the most widely held positions, ignoring the extremes.

Figure 3.5 indicates that the anticipated warming in northern latitudes due to an effective doubling of greenhouse gases may be as high as, or greater than, $6^{\circ} \mathrm{C}$. Only one paper addresses anticipated temperature increases in Alberta; it suggests that in Alberta the anticipated increase in average temperature under an effective doubling of greenhouse gases is in the range of 5 to $5.9^{\circ} \mathrm{C}$ (Appendix C).

\section{Temperature Increase In Northern Latitudes Predicted For An Effective Doubling Of Greenhouse Gases}

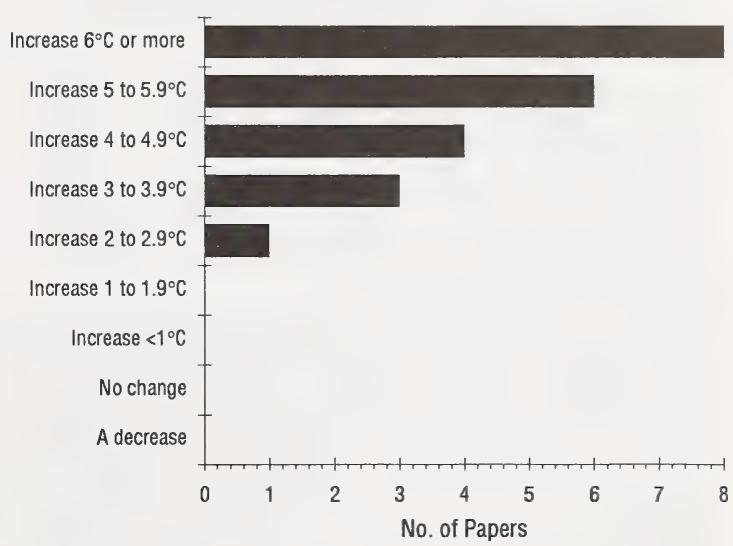

Figure 3.5 Number of papers that suggest that the increase in temperature in northern latitudes will be of stated magnitude when the greenhouse gas concentration in the atmosphere becomes equivalent to a doubling of the pre-industrial concentration of carbon dioxide. 
Most papers suggest that an effective doubling of greenhouse gases will result in both increases and decreases in precipitation depending upon location and season with an overall global increase (see Appendix C). Interest in obtaining estimates of precipitation changes stems largely from concern over water availability. To assess impact on water availability, soil moisture and evaporation must be considered along with changes in precipitation. A small portion of the publications (13 of 501) address the topic of weather extremes. These 13 suggest that an enhanced greenhouse effect will cause intensification of weather extremes. Drought frequency might be expected to increase, as would floods. Hurricane intensity might increase and monsoonal circulations strengthen. More intense and stormy conditions could include enhanced winter precipitation in high latitudes, intensified rains in tropical latitudes and perhaps a decrease in summer rainfall in mid-latitudes.

\subsection{Monitoring of Greenhouse Gases and Climate}

When considering future climate change, it is appropriate to look at the historical record of climate variation. From it we can learn about the range of natural climate variability to see how it compares with what we expect in the future and also look for evidence of recent climate change due to man's activities.

Climate varies naturally on all time scales from hundreds of millions of years down to year-to-year. Prominent in the earth's history have been the 100,000 year glacial-interglacial cycles when climate was mostly cooler than at present. Global surface temperatures have typically varied by 5 to $7^{\circ} \mathrm{C}$ through these cycles. Since the end of the last ice age about 10,000 years ago, global surface temperatures have probably fluctuated by little more than $1^{\circ} \mathrm{C}$.

The instrumental record of surface temperatures is fragmentary until the mid-nineteenth century after which it slowly improves. Because of different methods of measurement, historical records have to be made compatible with modern observations, introducing some uncertainty. Patterns of observed warming show substantial regional diversity (with some regions indicating cooling) which suggests that future regional temperature changes are likely to differ considerably from a global average. The size of the warming over the last century is broadly consistent with the predictions of climate models, but is also of the same magnitude as natural climate variability. The unequivocal detection of an enhanced greenhouse effect from observations of climate is not likely for another decade or more.
Because increases in the concentrations of greenhouse gases in the atmosphere are thought to be likely to produce global warming, it is appropriate to monitor concentrations of such gases as well.

\subsubsection{Results from the Literature Review}

Out of the 501 papers that were reviewed, 121 address the changing of the earth's atmosphere. With respect to the components of the atmosphere that are changing, the majority address carbon dioxide, as is shown in Figure 3.6

\section{Components Of The Atmosphere That Are Changing}

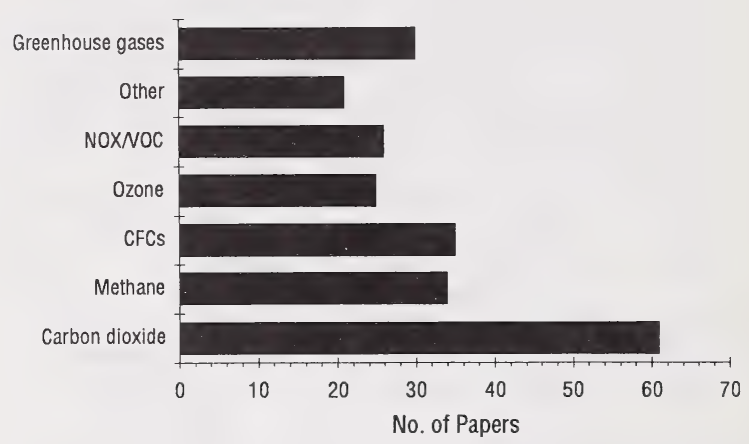

Figure 3.6 Number of papers that suggest the various components of the atmosphere are changing: the concentration of carbon dioxide, of methane, of chlorofluorocarbons (CFCs), of ozone, of nitrogen oxides and volatile organic compounds (NOx/VOC), other components (such as water vapour, sulphur compounds, carbon monoxide, volcanic dust) and of unspecified greenhouse gases.

With respect to monitoring changes in climate, only 80 entries on the questionnaires deal with this subject, most indicate that an increase in temperature has been observed over the past decade and over the past century both at the global and regional scale. However, only a few studies have computed the statistical significance of such observations. No conclusions are generally drawn with respect to changes in precipitation or weather extremes in the past decade or century. Most of the publications that indicate that increases in global temperature have been observed suggest that the observed increases are consistent with a change in the composition of the earth's atmosphere. 


\subsection{Potential Impacts of Climate Change}

Comprehensive estimates of physical and biological effects of climate change at the regional level are difficult. Confidence in regional estimates of critical climate factors is low. This is particularly true of precipitation and soil moisture. Moreover, there are several scientific uncertainties regarding the relationship between climate change and biological effects and between these effects and socio-economic consequences. Finally, the issue of timing and rates of change need to be considered. There will be lags between:

1) emission of greenhouse gases and doubling of concentrations;

2) doubling of greenhouse gas concentrations and changes in climate;

3) changes in climate and resultant physical and biological effects; and

4) changes in physical and ecological effects and resultant socio-economic consequences.

Because of these uncertainties, precise predictions cannot be made with respect to potential impacts of climate change. However, some gener ul conclusions can be reached, even with the current state of knowledge.

Because species respond differently to climate change, some will increase in abundance and/or range while others will decrease. Ecosystems will therefore change in structure and composition. Ecosystem structure and species distribution are particularly sensitive to the rate of change of climate. The rate of projected climate change is likely to be faster than the ability of some species to respond and adapt. In other words, it is likely that there will be winners and losers.

Changes in climate are likely to have an important effect on agriculture. Longer growing seasons and more carbon dioxide in the atmosphere may have a positive effect. But negative impacts could be felt at the regional level as a result of changes in weather, diseases, pests and weeds. An increase in drought risk

potentially represents the most serious impact of climate change on agriculture at both the regional and global levels.

With forestry, fire severity may increase. Major forest-type zones and species ranges could shift significantly as a result of climate change. Boreal forests and forests in arid and semi-arid regions are likely to be particularly sensitive. Climate will probably change much faster than tree species can migrate naturally.
Relatively small climate changes can cause large water resource problems especially in arid and semi-arid regions and the humid areas where demand or pollution have led to water scarcity. It appears that many areas will have increased precipitation, soil moisture and water storage, thus altering patterns of agriculture and other water use. In such areas, water management practices such as urban storm drainage systems may require increased capacity. Water

availability will decrease in other areas. This has significant implications for agriculture, for water storage and distribution, and for hydroelectric power generation. Water demand may also change.

Major health impacts are possible, especially in large urban areas, owing to changes in water and land availability and increased health problems due to heat stress and spreading of infection. More heat waves could increase mortality. Increased air pollution (closely related to climate change) may adversely affect health. Finally, parasitic and viral diseases have the potential for increase and reintroduction in many countries.

Global warming will accelerate sea-level rise, modify ocean circulation and change marine ecosystems with considerable socio-economic consequences. Permafrost, which underlies 20 to 25 per cent of the land mass of the northern hemisphere, could experience significant degradation within 40 to 50 years. Natural hazards such as coastal or river flooding, severe drought, landslides, severe wind storms and tropical storms may pose an increased threat to human settlements. These changes could result in large migrations of people, leading to severe disruptions of settlement patterns and social instability in some areas over a number of years.

Climate change will also affect the regional distribution of renewable energy resources and the availability of biomass. Also, the energy sector may be affected by response strategies against global warming, such as a policy of emission reduction. This may be among the most significant energy sector impacts in many developed countries, increasing opportunities for technologies that produce less greenhouse gases. 


\subsubsection{Results from the Literature Review}

The publications dealing with potential impacts of climate change were analyzed in two ways: one was on a region-by-region basis, the other on a sector-by-sector basis. Not enough information was available to analyze potential impacts on a sector-by-sector basis within each region. The questionnaire identified four regions: the world, Canada, the Prairies and Alberta. Results for these regions are in Appendix C. In general, mainly negative impacts are anticipated for the world, both positive and negative impacts are anticipated for Canada and the Prairies. Only a few publications deal with impacts in Alberta; these are split between positive and negative impacts.

The questionnaire identified 12 sectors with respect to potential impacts of climate change. Results for the most important of these (from an Alberta perspective) are shown in Figures 3.7, 3.8 and 3.9. The remaining results are in Appendix C.

\section{Potential Impacts On Agriculture Of An Effective Doubling Of Greenhouse Gases}

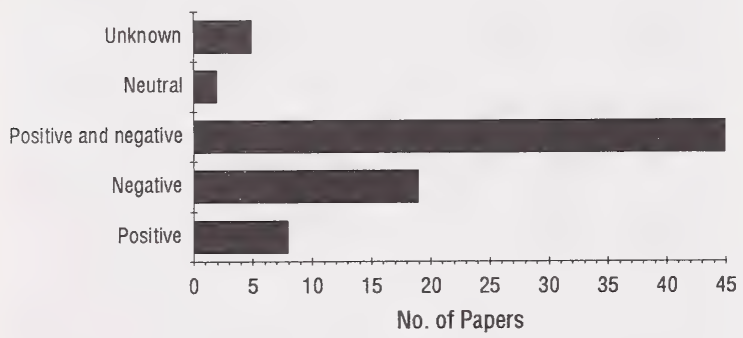

Figure 3.7 Number of papers that suggest positive, negative, both positive and negative, or neutral impacts, or impacts of unknown consequences, on agriculture, from an effective doubling of the pre-industrial concentration of carbon dioxide.
Potential Impacts On Forestry

Of An Effective Doubling

Of Greenhouse Gases

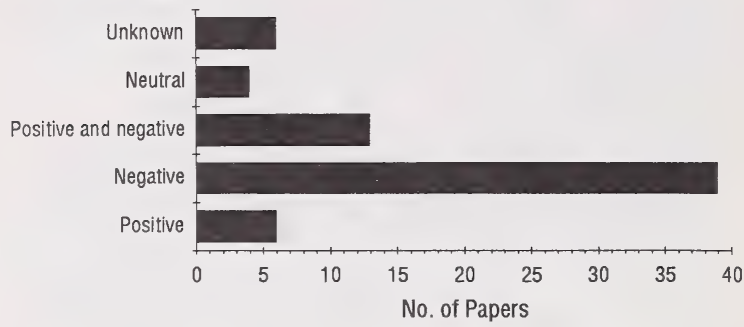

Figure 3.8 Number of papers that suggest positive, negative, both positive and negative, or neutral impacts, or impacts of unknown consequences, on forestry, from an effective doubling of the pre-industrial concentration of carbon dioxide.

\section{Potential Impacts On Health Of An Effective Doubling Of Greenhouse Gases}

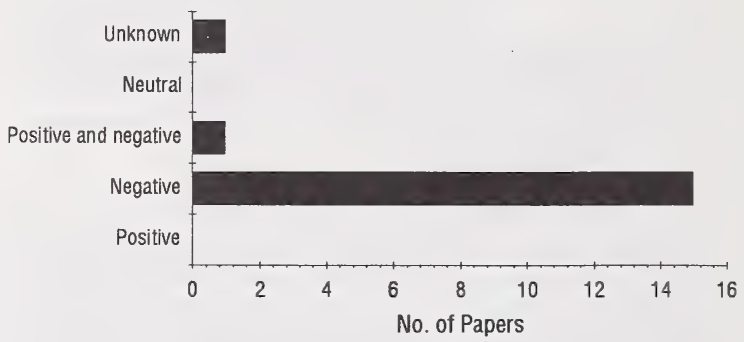

Figure 3.9 Number of papers that suggest positive, negative, both positive and negative, or neutral impacts, or impacts of unknown consequences, on health, from an effective doubling of the pre-industrial concentration of carbon dioxide.

With respect to agriculture, both positive and negative impacts are identified. Mainly negative impacts are indicated for forestry and health. For the energy sector, positive and negative impacts are cited. For the economy as a whole, mostly negative impacts are anticipated. 


\subsection{Potential Response Strategies}

A wide range of human activities results in the release into the atmosphere of greenhouse gases, particularly carbon dioxide, methane, CFCs, and nitrous oxide. Anthropogenic (man-made) emissions can be categorized as arising from energy production and use, non-energy industrial activity (primarily the production and use of CFCs), agricultural systems and changes in land-use patterns (including deforestation and biomass burning). Greenhouse gas emissions from most sources are likely to increase significantly in the future.

Because climate change could potentially result in significant impacts on the global environment and human activities (Section 3.3), it is important to begin considering what response measures might be taken. A wide range of options is available including measures both to limit net greenhouse gas emissions (limitation strategies) and to increase the ability of society to adapt to a changing climate (adaptation strategies).

The consideration of climate change response strategies, however, presents formidable difficulties for policy makers because the available information is inadequate. For instance, scientific uncertainties remain regarding the magnitude, timing, rate, and regional consequences of potential climate change. Uncertainty exists as to how effective specific response options would be in averting potential climate changes. It also exists regarding costs, effects on economic growth, and other economic and social implications of specific response options. These uncertainties can be reduced through accelerated and coordinated research programs on the scientific and socio-economic aspects of the issue and through increased monitoring of greenhouse gas concentrations, of the climate, of sea level and the extent of snow and ice covers.

There are also some response options that may be economically and socially feasible to implement in the near-term, while others, because they are not yet technically or economically viable, may be more appropriate in the longer term. The degree to which options are viable will vary considerably depending on the region or country involved.

Options for limiting net emissions of greenhouse gases (limitation strategies) include measures which limit emissions from greenhouse gas sources and which increase the use and protection of natural repositories for absorbing greenhouse gases, such as forests.
Various options have been identified for reducing greenhouse gas emissions:

- efficiency improvements and conservation in energy supply, conversion, and end use in existing and new facilities;

- fuel substitution to energy sources which have lower greenhouse gas emissions;

- reduction of greenhouse gas emissions by removal and capture;

- elimination of the use of CFCs;

- improved management of livestock feeding and wastes, fertilizer use and agricultural practices, improved land use (e.g. reforestation or afforestation), improved forest management, improved waste management (e.g. development of methane recovery systems for landfill and wastewater treatment facilities);

- changes in lifestyle.

Because it is believed there will be a lag time between emissions and subsequent climate change, the climate may already be committed to a degree of change. Implementation of adaptation strategies may be necessary regardless of any limitation actions which may be taken.

Adaptation strategies can be divided into two broad categories:

- coastal zone management (options which maximize the ability of coastal regions to adapt to the projected sea level rise and to reduce vulnerability to storms); and

- resource use and management (options which address the potential impacts of global climate change on food security, water availability, natural and managed ecosystems, land, and biodiversity). 


\subsubsection{Results from the Literature Review}

In the publications reviewed, limitation strategies are suggested, in general, for emissions of carbon dioxide, methane, CFCs, ozone and nitrogen oxides, and volatile organic compounds.

Figure 3.10 shows that carbon dioxide is most frequently cited for limitation strategies

\section{Suggested Emission Limitation Strategies In Response \\ To Global Warming}

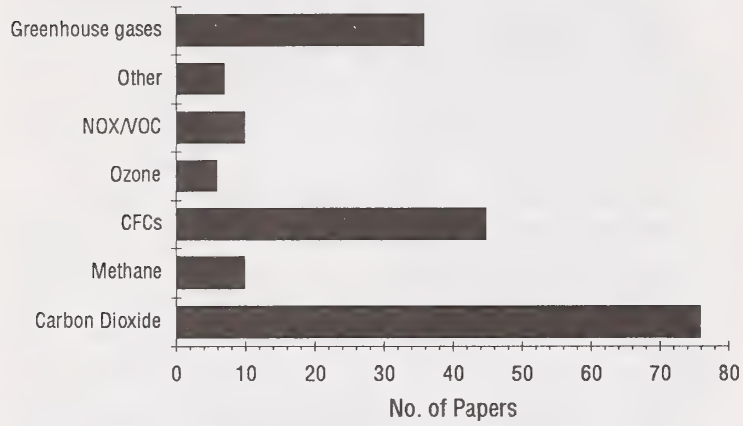

Figure 3.10 Number of papers that suggest limitation of emissions of various gases in response to global warming: the gases are carbon dioxide, methane, chlorofluorocarbons (CFCs), ozone, nitrogen oxides and volatile organic compounds, other gases (mainly sulphur compounds) and unspecified greenhouse gases.

With respect to adaptation strategies (Appendix C) water resource management, agriculture and coastal policies are the sectors most often cited for the development of adaptation strategies.

\subsection{Technological Solutions}

The application of existing and new technologies is vital to any effort to address global climate change. There will be a need to: limit or reduce anthropogenic greenhouse gas emissions; absorb such gases by protecting and increasing sinks; adapt human activities and resource use and management to the impacts of climate change; and detect, monitor and predict climate change and its impacts. Technological development could be pursued in a wide range of activities such as energy, industry, agriculture, transport, water supply, coastal protection, management of natural resources, and construction.

\subsubsection{Results from the Literature Review}

The publications reviewed deal mostly with technological solutions applicable to the energy sector such as energy efficiency, fuel substitution, carbon dioxide capture and clean combustion. Reforestation and technology related to landfills are technological solutions mentioned for other economic sectors. Some publications even mention long shots such as climate modification -- the dispersion of dust in the stratosphere to reflect incoming solar radiation. Figure 3.11 shows that simple options such as energy efficiency and fuel substitution, which are economically attractive even now, are suggested most frequently. Note that fuel substitution includes the nuclear option.

\section{Suggested Technological Solutions In Response To Global Warming}

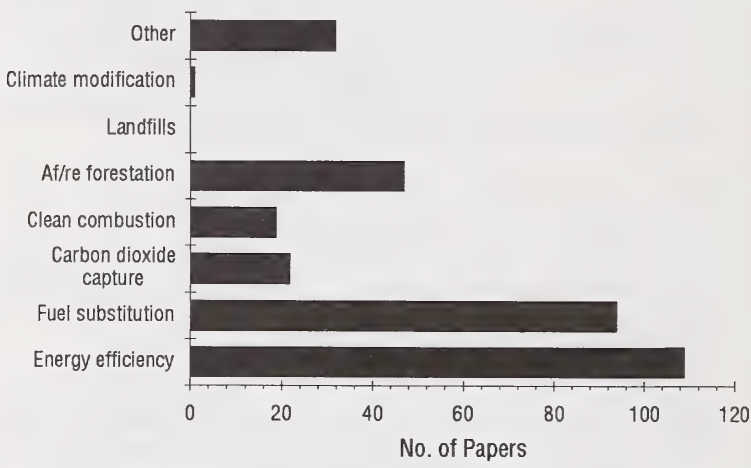

Figure 3.11 Number of papers that suggest the various technological solutions to global warming: the technological solutions are energy efficiency, the substitution of "cleaner" fuels, the capture of carbon dioxide emissions, cleaner combustion techniques, reforestation or afforestation (to increase carbon dioxide sinks), technology for capturing gases from landfills, climate modification (the distribution of dust in the stratosphere to reflect solar radiation), and other technologies (eg. recycling, research and development in general). 


\subsection{SUMMARY}

A total of 501 recent (1988 to 1990) publications have been reviewed. These publications comprise a reasonably representative sample that gives fair representation to all sides of the issue even though the sample is not all-inclusive. Topics covered by the sample of publications are: climate modelling, monitoring of the atmosphere and climate, potential impacts of climate change, potential response strategies, and technological solutions.

The results of the review show that, with respect to modelling climate and monitoring the atmosphere and climate, a strong consensus exists within the scientific community and those who interpret science on the magnitude, timing and cause of potential climate change. This is not an issue that has been promoted by a few vociferous champions. The most common position on these topics is summarized in Table 4.1.

\section{Table 4.1}

Most Common Positions in the Scientific Community with respect to the Magnitude and Timing of Global Warming

\begin{tabular}{l|l} 
Issue & Most Common Position \\
\hline $\begin{array}{l}\text { Time of effective doubling } \\
\text { of pre-industrial carbon } \\
\text { dioxide concentrations }\end{array}$ & 2050 \\
$\begin{array}{l}\text { Magnitude of anticipated } \\
\text { warming under an effective } \\
\text { doubling: } \\
\text { globally } \\
\text { northern latitudes only }\end{array}$ & $\begin{array}{l}3 \text { to } 3.9^{\circ} \mathrm{C} \\
\text { greater than } 6^{\circ} \mathrm{C}\end{array}$ \\
$\begin{array}{l}\text { Effect on precipitation of } \\
\text { effective doubling }\end{array}$ & $\begin{array}{l}\text { both increases and } \\
\text { decreases depending upon } \\
\text { location }\end{array}$ \\
$\begin{array}{l}\text { Cause of observed global } \\
\text { warming in the past } \\
\text { century/decade }\end{array}$ & $\begin{array}{l}\text { observed warming is } \\
\text { consistent with enhanced } \\
\text { greenhouse effect }\end{array}$ \\
\hline
\end{tabular}

Strong consensus also exists about some potential impacts, strategies and technological solutions. These are summarized in Table 4.2.
Table 4.2

Most Common Positions in the Scientific Community with respect to Potential Impacts of and Solutions to Global Warming

\begin{tabular}{l|l} 
Impact/Solution & Most Common Position \\
\hline $\begin{array}{l}\text { Impact on World } \\
\text { Impact on Canada/Prairies }\end{array}$ & $\begin{array}{l}\text { strongly negative } \\
\text { both negative and positive } \\
\text { impacts } \\
\text { both negative and positive } \\
\text { impacts }\end{array}$ \\
$\begin{array}{l}\text { Impact on Agriculture } \\
\text { strongly negative } \\
\text { Impact on Forestry } \\
\begin{array}{l}\text { Impact on Health } \\
\text { Adaptation Strategies } \\
\text { suggested for }\end{array}\end{array}$ & $\begin{array}{l}\text { agriculture and water } \\
\text { resource management } \\
\text { Limitation Strategies } \\
\text { suggested for }\end{array}$ \\
$\begin{array}{l}\text { Technological solutions } \\
\text { suggested }\end{array}$ & $\begin{array}{l}\text { and CFCs } \\
\text { energy efficiency and fuel } \\
\text { substitution }\end{array}$ \\
\hline
\end{tabular}

Although substantial numbers of papers address the major topics, the numbers that deal with important subsets soon become quite small. For instance, estimates for global warming under an effective doubling of greenhouse gases is addressed in 111 papers. But the anticipated warming in northern latitudes is addressed in only 20 papers. Only one paper (Wong et al., 1989) deals with the anticipated warming in Alberta.

With respect to Alberta, Wong et al. (1989) suggest that, under an effective doubling of greenhouse gases, on average Alberta will be $5^{\circ} \mathrm{C}$ warmer than its current normal climate. Two publications suggest that Alberta will have an increase in precipitation under an effective doubling of greenhouse gases and one suggests that there will be increases and decreases, depending upon location and season. Wong et al. (1989) also found that there has been a gradual increase in temperature in Alberta over the past century and a greater overall increase in temperature in the $1980 \mathrm{~s}$. With respect to potential impacts in Alberta of an effective doubling of greenhouse gases, both positive and negative impacts are suggested. However, there were only eight references to potential impacts in Alberta. 
Of the 501 publications reviewed, 151 are in the category of refereed, non-review-type (i.e. original research) papers which are the primary data set. One interesting result from the analysis is that review-type papers tend to focus on the most popular point of view regarding the timing and magnitude of changes anticipated; the original research papers produce a broader spectrum of opinion.

\subsection{REFERENCES}

Hengeveld, H., 1990: The Canadian Climate

Centre $2 \mathrm{XCO}_{2}$ Experiment Preliminary Results. $\mathrm{C0}_{2} /$ Climate Report Newsletter, Number 90-01, Environment Canada, Downsview, Ont.

Petri, H., 1990: Greenhouse Effect and Global Warming Database. Alberta Research Council Report.

United States Environmental Protection Agency, 1989: Policy Options for Stabilizing Global Climate: Draft report to congress. EPA Office of Policy Planning and Evaluation.

Wong, R.K.W., M. English, F.D. Barlow, L. Cheng and K.R. Tremaine, 1989: Towards a Strategy for Adapting to Climate Change in Alberta, Alberta Research Council Report. 
A Case Study of the Effects of $\mathrm{CO}_{2}$-Induced Climatic Warming on Forest Growth and the Forest Sector: A. Productivity Reactions of Northern Boreal Forests, by P Kauppi, M Posch

The Impact of Climatic Variations on Agriculture, V 1: Assessments in Cool Temperate and Cold Regions, Section 5, 1990, P 183-195 (13)

A Case Study of the Effects of $\mathrm{CO}_{2}$-Induced Climatic Warming on Forest Growth and the Forest Sector: B. Economic Effects on the World's Forest Sector, by C S Binkley

The Impact of Climatic Variations on Agriculture, V 1: Assessments in Cool Temperate and Cold Regions, Section 1, 1990, P 197-218 (22)

A Cool Solution to Global Warming, by D Olivier New Scientist, 12 May 1990, P $42-45$ (4)

A GCM Analysis of the Cloud Optical Depth Feedback, by E Roeckner

Symposium on the Role of Climate in Atmosphere Chemistry and Global Climate, American Meteorological Society, Anaheim, California, 30 Jan-3, Feb, 1989, P 67-68 (2)

A Mechanism For Greenhouse-Induced Collapse of Mammalian Faunas, by D M McLean Coping With Climate Change, Proceedings, Second North American Conference on Preparing For Climate Change: A Cooperative Approach, The Climate Institute, Washington, DC, June 1989, P 263-267 (5)

A Model to Estimate Carbon Dioxide Recycling in Forests Using 13C/12C Ratios and Concentrations of Ambient Carbon Dioxide, by L D S L O Sternberg Agriculture For Meteorology, V 48, 1989, P 163-173 (11)

A Projection of Future Sea Level, by J Oerlemans Climatic Change, V 15, 1989, P 151-174 (24)

A Really Worst Case Scenario, by J L Jacobson Oceanus, V 32, N 2, 1989, P 36-43 (8)

A Study of the Impact of Soil Moisture and Surface Albedo Changes on Global Climate Using the MRI.GCM-I, by K Yamazaki Journal of the Meteorological Society of Japan, V 67, N 1, 1989, P 123-146 (24)

A Summary of Climate Impact Studies on Agriculture: The U.S. Environmental Protection Agency's Report to Congress on The Potential Effects of Global Climate Change on the United States, by C Rosenzweig Coping With Climate Change, Proceedings, Second North American Conference On Preparing For Climate Change: A Cooperative Approach, The Climate Institute, Washington, DC, June 1989, P 192-196 (5)

A Survey of Informed Opinion Regarding the Nature and Reality of a "Global Greenhouse Warming", by D H Slade

Climatic Change, V 16, 1990, P 1-4 (4)
A Systems Approach to a Technology-Based Response to the Greenhouse Gas Issue, by L D Hamilton

Energy Technologies for Reducing Emissions of Greenhouse Gases, Proceedings of an Expert's Seminar, V 1, Paris, 12-14 April 1989, P 207-238 (32)

A Tale of Ten Fallacies: The Skeptical Enquirer's View of the Carbon Dioxide/Climate Controversy, by W E Reifsnyder

Agriculture For Meteorology, N 47, 1989, P 349-371 (23)

A Technical Fix for the Greenhouse Effect, by S Watts New Scientist, 5 May 1990, P 34 (1)

Abstract: Effects on Water Resources, by D R Cuthbert Report of the First US - Canada Symposium on Impacts of Climate Change on the Great Lakes Basin, National Climate Program Office, Canadian Climate Centre, US Environmental Protection Agency, Midwestern Climate Center, Oak Brook, Illinois, 27-29 Sept 1988, P 160-161 (2)

Adapting Future Agriculture to Changes in Climate, by W E Easterling III, M L Parry, P R Crosson Greenhouse Warming: Abatement and Adaptation, Proceedings of a Workshop, National Oceanic and Atmospheric Administration, US Department of Energy, US Department of Agriculture, US Environmental Protection Agency, International Federal Institute for Advanced Study, Resources for the Future, Washington, DC, 14-15 June 1988, P 91-104 (14)

Adapting Water Resources Management to Global Climate Change, by $\mathrm{P}$ Williams Climatic Change, V 15, 1989, P 83-93(11)

Agenda for the Next Decade: Canadian Perspectives, by $\mathrm{D} \mathrm{K}$ Dawson

Coping With Climate Change, Proceedings, Second North American Conference on Preparing For Climate Change: A Cooperative Approach, The Climate Institute, Washington, DC, June 1989, P 50-56 (7)

Alternatives to CFCs, by C E Tane Ozone Depletion: Health and Environmental Consequences, Chapter 17, 1989, P 235-241 (7)

Amazon Capims (Floating Grassmats): A Source of 13C Enriched Methane to the Troposphere, by J Chanton, P Crill, K Bartlett, C Martens Geophysical Research Letters, V 16, N 8, Aug 1989, P 799-802 (4)

An Analysis of the Montreal Protocol on Substances that Deplete the Ozone Layer

The Challenge of Global Warming, Chapter 20, 1989, P 291-304 (14)

An Assessment of the Effects of Climatic Change on Agriculture, by M L Parry, T R Carter Climatic Change, V 15, 1989, P 95-116 (22) 
An Effective Greenhouse Gas Emission Reduction Strategy for the Protection of the Global Climate, by W Bach

Energy Technologies for Reducing Emissions of Greenhouse Gases, Proceedings of an Expert's Seminar, V 1, Paris, 12-14 April 1989, P 489-507 (19)

An Overview of Potential Effects of Rapid Warming on the Canadian Arctic, by S C Lonergan

Coping With Climate Change, Proceedings, Second North American Conference On Preparing For Climate Change: A Cooperative Approach, The Climate Institute, Washington, DC, June 1989, P 464-468 (5)

An Overview of the EPA Studies of the Potential Impacts of Climate Change on the Great Lakes Region, by J B Smith

Coping With Climate Change, Proceedings, Second North American Conference On Preparing For Climate Change: A Cooperative Approach, The Climate Institute, Washington, DC, June 1989, P 532-542 (10)

An Upper Limit to the Greenhouse Effect of Earth's Atmosphere, by S B Idso

Theoretical Applied Climatology, V 40, 1989,

P 171-174 (4)

Analysis of Effects of Atmospheric Carbon Dioxide and Ozone on Cotton Yield Trends, by V R Reddy,

D N Baker, J M McKinion

Journal of Environmental Quality, V 18, Oct-Dec 1989, P 427-432 (6)

Analytical Problems in Assessing Renewable Energy Sources, by M J Grubb

Energy Technologies for Reducing Emissions of Greenhouse Gases, Proceedings of an Expert's Seminar, V 2, Paris, 12-14 April 1989, P 583-593 (11)

Anticipating Climatic Change, by J Jager Environment, V 30, N 7, Sept 1988, P 12-15, 30 (5)

Anticipating the Frequency Distribution of Precipitation if Climate Change Alters its Mean, by P E Waggoner

Agriculture For Meteorology, N 47, 1989, P 321-337 (17)

Arctic Ozone Springs a Leak as Winter Draws to a Close, by J Gribbin New Scientist, 22 July 1989 P 27 (1)

Are We Missing the Grass for the Trees? by P de Groot New Scientist, 6 Jan 1990, P 29-30 (2)

Artificial Photochemical and Electrochemical Systems for the Reduction of Carbon Dioxide: Conversion of Solar Energy into Chemical Energy, by R Ziessel Energy Technologies For Reducing Emissions of Greenhouse Gases, Proceedings of an Expert's Seminar, V 2, Paris, 12-14 April 1989, P 249-250
Assessing and Managing the Risks of Climate Change, by P R Portney

Greenhouse Warming: Abatement and Adaptation, Proceedings of a Workshop, National Oceanic and Atmospheric Administration, US Department of Energy, US Department of Agriculture, US Environmental Protection Agency, International Federal Institute for Advanced Study, Resources for the Future, Washington, DC, 14-15 June 1988, P 83-88 (6)

Assessing Impacts of Climatic Warming on Fresh Water Fisheries in N. America, by $\mathrm{J} D$ Meisner Climatological Bulletin, V 22, N 1, 1988, P 48-49

Assessing the Effects of Climatic Changes on

Snowpack and Streamflow, by K R Cooley Western Snow Conference, 18-20 April 1989, P 118-121 (4)

Assessing the Threat to Antiques Posed by Climate Change, Sea Level Rise and Air Pollution, by H Sadek, $\mathrm{J}$ C Topping Jr Coping With Climate Change, Proceedings, Second North American Conference On Preparing For Climate Change: A Cooperative Approach, The Climate Institute, Washington, DC, June 1989, P 691-696 (6)

Atmospheric Acidification: Projections for the Future, by J N Galloway

Ambio, V 18, N 3, 1989, P 161-166 (6)

Atmospheric and Climatic Change in the Arctic and Antarctic, by J B Maxwell, L A Barrie Ambio, V 18, N 1, 1989, P 42-49 (8)

Atmospheric Carbon Dioxide Measurements at Cape Matatula, American Samoa, 1976-1987, by

L S Waterman, D W Nelson, W D Komhyr, T B Harris, $\mathrm{K}$ W Thonung, $\mathrm{P}$ Tans

Journal of Geophysical Research, V 94, N D12, 20 Oct 1989 , P 14817-14829 (13)

Atmospheric $\mathrm{CO}_{2}$ : Causes, Effects and Options, by W A Nierenberg

Chemical Engineering Progress, Aug 1989, P 27-36 (10)

Atmospheric Methane: Recent Global Trends, by M A K Khalil, R A Rasmussen

Environmental Science Technology, V 24, N 4, 1990 , P 549-553 (5)

Atmospheric Ozone, by R T Watson The Changing Atmosphere: Implications for Global Security Proceedings, Secretariat of the World Meteorological Organization, Toronto, 27-30 June 1988, P 70-91 (22)

Atmospheric Trace Gases and Global Climate:

A Seasonal Model Study, by W C Wang, G Molner,

M K W Ko, S Goldenberg, N D Sze Tellus, V 42B, 1990, P 149-161 (13)

Atmospheric $14 \mathrm{C}$ and Century-Scale Solar Oscillations, by M Stuiver, T F Braziunas Nature, V 338, 30 March 1989, P 405-408 (4)

Bad News From the Arctic With Signs of Dry Nitrogen Removal, by $\mathrm{R} L$ Jones Nature, V 344, 22 March 1990, P 294-295 (2) 
Basic Points of View on the Evaluation of Energy Technologies Towards the Global Changes: Economics and Energy Security, by A Kinoshita

Energy Technologies for Reducing Emissions of Greenhouse Gases, Proceedings of an Expert's

Seminar, V 1, Paris, 12-14 April 1989, P 239- 246 (8)

Beach Response Strategies to Accelerated Sea-Level Rise, by S P Leatherman

Coping With Climate Change, Proceedings, Second North American Conference on Preparing For Climate Change: A Cooperative Approach, The Climate Institute, Washington, DC, June 1989, P 353-358 (6)

Biology Not Pollution Controls the Clouds Above the Pacific

New Scientist, 22 July 1989, P 32 (1)

Biomass Gasifier/Gas Turbine Power and the Greenhouse Warming, by $\mathrm{R} \mathrm{H}$ Williams

Energy Technologies For Reducing Emissions of Greenhouse Gases, Proceedings of an Expert's Seminar, V 2, Paris, 12-14 April 1989, P 197-248 (52)

Biotic Causes and Effects of the Disruption of the Global Carbon Cycle, by G M Woodwell

The Challenge of Global Warming, Chapter 5, 1989, P 71-81 (11)

Blueprint for Clear Skies, by M Cone Sierra, July-August 1989, P 16, 18 (2)

Boreal Forests and the Global Carbon Cycle, by P Kauppi, M Posch

Science, V 243, 24 March 1989, P 1535-1536

Can Market Mechanisms Ameliorate the rects of Long-Term Climate Change, by C Weiss, Jr Climatic Change, V 15, 1989, P 299-307 (9)

Canada, Carbon Dioxide, and the Greenhouse Effect, by L Hughes, S Scott

Environment, V 31, N 9, Nov 1989, P 4-5, 45 (3)

Carbon Dioxide and Climate Changes: Implications for Mankind's Future, by W W Kellogg Global Climate Change, Human and Natural Influences, Chapter 2, 1989, P 37-65 (29)

Carbon Dioxide and Global Change: Earth in Transition, by S B Idso Institute of Biospheric Research Inc. July 1989 (150)

Carbon Dioxide Emissions in a Methane Economy, by J H Ausubel, A Grubler, N Nakicenovic Climatic Change, V 12, 1988, P 245-263 (19)

Carbon Dioxide Recovery and Utilisation in the Synthesis of Fine Chemicals and Fuels: A Strategy for Controlling the Greenhouse Effect, by M Aresta Energy Technologies for Reducing Emissions of Greenhouse Gases, Proceedings of an Expert's Seminar, V 1, Paris, 12-14 April 1989, P 599- 617 (19)

Carbon Emissions Trends in Canadian Transportation, by $\mathrm{P}$ S Jessup

Coping With Climate Change, Proceedings, Second North American Conference On Preparing For Climate Change: A Cooperative Approach, The Climate Institute, Washington, DC, June 1989, P 585-588
Carbon Monoxide and the Burning Earth, by

R E Newell, H G Reichle, Jr, W Seiler

Scientific American, Oct 1989, P 82-88 (7)

Carbon-14 in Methane Sources and in Atmospheric

Methane: The Contribution From Fossil Carbon, by

M Wahlen, N Tanaka, R Henry, B Deck, J Zeglen,

J S Vogel, J Southon, A Shemesh, R Fairbanks,

W Broecker

Science, V 245, 21 July 1989, P 286-290 (5)

Carbonaceous Aerosols From Different Tropical

Biomass Burning Sources, by $\mathrm{H}$ Cachier,

M P Bremond, P Buat-Menard

Nature, V 340, N 6232, 3 Aug 1989, P 371-373 (3)

Change in Climate Variability in the 21st Century, by

D Rind, R Goldberg, R Ruedy

Climatic Change, N 14, 1989, P 5-37 (33)

Changes in Soil Moisture, by S Manabe

The Challenge of Global Warming, Chapter 10, 1989,

P 146-149 (5)

Changes of Tropical Sea-Air Interaction Process Over a 30 Year Period, by H Flohn, A Kapala

Nature, V 338, N 6212, 16 March 1989, P 244-246 (3)

Changing Climatic Resources for the Western

Canadian Boreal Forest, by E E Wheaton, J P Thorpe Saskatchewan Research Council Publication N E-906-14-D-89, March 1989, (17)

Changing Prospects For Natural Gas in the United

States, by W M Burnett, S D Ban

Science, V 244, 21 April 1989, P 305-310 (6)

China Leads New Surge in Output of Greenhouse Gas, by $\mathrm{R}$ Milne

New Scientist, 1 July 1989, P 38 (1)

Chlorofluorocarbons and the Depletion of Stratospheric Ozone, by F S Rowland

American Scientist, V 77, Jan-Feb 1989, P 36-45 (10)

Climate and Agriculture: Case of the Fruit Belt in Lower Michigan, by N D Strommen

Report of the First US - Canada Symposium on Impacts of Climate Change on the Great Lakes Basin, National Climate Program Office, Canadian Climate Centre, US Environmental Protection Agency, Midwestern Climate Center, Oak Brook, Illinois, 27-29 Sept 1988, P 194-195 (2)

Climate and Forests, by R A Sedjo, A M Solomon Greenhouse Warming: Abatement and Adaptation, Proceedings of a Workshop, National Oceanic and Atmospheric Administration, US Department of Energy, US Department of Agriculture, US Environmental Protection Agency, International Federal Institute for Advanced Study, Resources for the Future, Washington, DC, 14-15 June 1988, P 105-119 (15)

Climate Change and $\mathrm{CO}_{2}$ Effects on Wheat and Corn in the Great Plains, by C Rosenzweig 6th Conference on Applied Climatology, Charleston, March 1989, P J26-J29 (4)

Climate Change and Environmental Pollution:

Physical and Biological Interaction, by M Oppenheimer Climatic Change, V 15, 1989, P 255-270 (16) 
Climate Change and Forest Fires, by M A Fosberg Coping With Climate Change, Proceedings, Second North American Conference On Preparing For Climate Change: A Cooperative Approach, The Climate Institute, Washington, DC, June 1989, P 292-296 (5)

Climate Change and Global Warming, by P Rogers Environmental Science Technology, V 24, N 4, 1990, P 428-430 (3)

Climate Change and Hydrologic and Atmospheric Issues: Lessons of the Past, by S A Changnon Report of the First US - Canada Symposium on Impacts of Climate Change on the Great Lakes Basin, National Climate Program Office, Canadian Climate Centre, US Environmental Protection Agency, Midwestern Climate Center, Oak Brook, Illinois, 27-29 Sept 1988, P 79-85 (7)

Climate Change and International Politics: Problems

Facing Developing Countries, by P H Gleick Ambio, V 18, N6, 1989, P 333-339 (7)

Climate Change and Mid-Latitudes Agriculture:

Perspective on Consequences and Policy Responses, by P Crosson

Climatic Change, V 15, 1989, P 51-73 (23)

Climate Change and Parasitic Diseases of Man and Domestic Livestock in the United States, by A Dobson Coping With Climate Change, Proceedings, Second North American Conference on Preparing For Climate Change: A Cooperative Approach, The Climate Institute, Washington, DC, June 1989, P 147-152 (6)

Climate Change and the Canadian Forest, by $J$ B Harrington Coping With Climate Change, Proceedings, Second North American Conference on Preparing For Climate Change: A Cooperative Approach, The Climate Institute, Washington, DC, June 1989, P 297-302 (6)

Climate Change and the IJC, by M Clamen Coping With Climate Change, Proceedings, Second North American Conference On Preparing For Climate Change: A Cooperative Approach, The Climate Institute, Washington, DC, June 1989, P 542-546 (5)

Climate Change and the Opportunities It May Bring, by $\mathrm{E} \mathrm{E}$ Wheaton Globe '90 International Conference, Vancouver, 19-23 Mar 1990 (6)

Climate Change and US Forest Markets, by

J L Regens, F W Cubbage, D G Hodges Coping With Climate Change, Proceedings, Second North American Conference On Preparing For Climate Change: A Cooperative Approach, The Climate Institute, Washington, DC, June 1989, P 303-309 (7)
Climate Change and Water Resource Management: Summary of Remarks to the Annual Meeting of UCOWR, by A D Hecht

Climate Change and Water Research: Research Needs and Opportunities, Proceedings, 1988 Annual Meeting Universities Council on Water Resources Inc, Washington State University, University Idaho, Coeur d'Alene, Idaho, 5-8 July 1988, P 51-52 (2)

Climate Change and Water Resources Management: Assessing Capacity for Institutional Adaptation in the Southeast, by M Meo, R E Deyle, L L Malaysa,

L A Wilson

Coping With Climate Change, Proceedings, Second North American Conference On Preparing For Climate Change: A Cooperative Approach, The Climate Institute, Washington, DC, June 1989, P 484-492 (9)

Climate Change and Water Supply, by D Moreau Climate Change and Water Research: Research Needs and Opportunities, Proceedings, 1988 Annual Meeting Universities Council on Water Resources Inc, Washington State University, University Idaho, Coeur d'Alene, Idaho, 5-8 July 1988, P 31-47 (17)

Climate Change and Water Use in Agriculture, by $S$ A Changnon

Climate Change and Water Research: Research Needs and Opportunities, Proceedings, 1988 Annual Meeting Universities Council on Water Resources Inc, Washington State University, University Idaho, Coeur d'Alene, Idaho, 5-8 July 1988, P 69-77 (9)

Climate Change by Increasing of Greenhouse Gases and Possible Countermeasure Technology, by

O Yokoyama

Energy Technologies For Reducing Emissions of Greenhouse Gases, Proceedings of an Expert's Seminar, V 2, Paris, 12-14 April 1989, P 397-409

Climate Change Effects on Fish, Wildlife and Other DOI Programs, by I M Goklany

Coping With Climate Change, Proceedings, Second North American Conference On Preparing For Climate Change: A Cooperative Approach, The Climate Institute, Washington, DC, June 1989, P 273-281 (9)

Climate Change Effects on Ontario's Water Quality, by J Bishop

Report of the First US - Canada Symposium on Impacts of Climate Change on the Great Lakes Basin, National Climate Program Office, Canadian Climate Centre, US Environmental Protection Agency, Midwestern Climate Center, Oak Brook, Illinois, 27-29 Sept 1988, P 177-181 (5)

Climate Change in the Great Lakes Region, by D W Phillips

Report of the First US - Canada Symposium on Impacts of Climate Change on the Great Lakes Basin, National Climate Program Office, Canadian Climate Centre, US Environmental Protection Agency, Midwestern Climate Center, Oak Brook, Illinois, 27-29 Sept 1988, P 19-42 (24)

Climate Change Puts the Heat on Ontario, by L Dotto Challenges, V 2, N 2, 1989 (6)

Climate Change, by NSCA

Clean Air, V 19, N 2, 1989, P 69-71 (3) 
Climate Change, $\mathrm{CO}_{2}$ Fertilization and

Evapotranspiration, by N J Rosenberg, M S McKenney, P Martin

Coping With Climate Change, Proceedings, Second North American Conference On Preparing For Climate Change: A Cooperative Approach, The Climate Institute, Washington, DC, June 1989, P 337- 347 (11)

Climate Change, Economic Growth and Energy Policy: A Recommended US Strategy for the Coming Decades, by A D Hecht, B R Doos

Climate Change, V 13, 1988, P 1-3 (3)

Climate Change, Intergenerational Equity and International Law: An Introductory Note, by E B Weiss

Climatic Change, V 15, 1989, P 327-335 (9)

Climate Change: High-Latitude Regions, by E F Roots Climatic Change, V 15, 1989, P 223-253 (31)

Climate Change: Problems of Limits and Policy Responses, by P R Crosson

Greenhouse Warming: Abatement and Adaptation, Proceeding of a Workshop, National Oceanic and Atmospheric Administration, US Department of Energy, US Department of Agriculture, US Environmental Protection Agency, International Federal Institute for Advanced Study, Resources for the Future, Washington, DC, 14-15 June 1988, P 69-82 (14)

Climate Change: The Implications for Securities Underwriting, by A Medioli

Coping With Climate Change, Proceedings, Second North American Conference On Preparing For Climate Change: A Cooperative Approach, The Climate Institute, Washington, DC, June 1989, P 406-411 (6)

Climate from a Modeling Point of View: In Reply to Comments by H W Ellsaesser, by A A Lacis Global Climate Change, Human and Natural Influences, Chapter 4, 1989, P 81-85 (5)

Climate Impacts of Methane Clathrates, by G J MacDonald Coping With Climate Change, Proceedings, Second North American Conference On Preparing For Climate Change: A Cooperative Approach, The Climate Institute, Washington, DC, June 1989, P 94- 101 (8)

Climate Scenarios for Impact Assessment, by

P J Robinson

6th Conference on Applied Climatology, Charleston, March 1989, P 174-177 (4)

Climate Sensitivity Due to Increased $\mathrm{CO}_{2}$ :

Experiments With a Coupled Atmosphere and Ocean General Circulation Model, by W M Washington, G A Meehl Climate Dynamics, V 4, 1989, P 1-38 (38)
Climate Sensitivity of the Great Lakes System, by F K Hare, S J Cohen

Report of the First US - Canada Symposium on Impacts of Climate Change on the Great Lakes Basin, National Climate Program Office, Canadian Climate Centre, US Environmental Protection Agency, Midwestern Climate Center, Oak Brook, Illinois, 27-29 Sept 1988, P 49-60 (12)

Climate Warming and Canada's Comparative Position in Agriculture, by B Smit

Climate Change Digest, CCD 89-01, 1989 (12)

Climate-Chemical Interactions and Effects of Changing Atmospheric Trace Gases, by

V Ramanathan, L Callis, R Cess, J Hansen, I Isaksen, W Kuhn, A Lacis, F Luther, J Mahlman, R Reck, M Schlesinger

Review of Geophysics, V 25, N 7, Aug 1987, P 1441-1482 (42)

Climatic Catastrophe: On the Horizon or Not? by A R Solow, J M Broadus

Oceanus, V 32, N 2, 1989, P 61-64 (4)

Climatic Change and Great Lakes Levels: The Impact on Shipping, by D Marchand, M Sanderson, D Howe, C Alpaugh

Climatic Change, V 12, 1988, P 107-133 (27)

Climatic Change in the Colorade Rocky Mountains: Estimates Based on Modern Climate at Lake Pleistocene Equilibrium Lines, by E M Leonard Arctic and Alpine Research, V 21, N 3, 1989, P 245-255 (11)

Climatic Change: A Review of Causes, by

$J$ B Harrington

Canadian Journal of Forest Resources, V 17, 1987, P 1313-1339 (27)

Climatic Warming and Increased Summer Aridity in Florida, USA, by $J$ M Coleman

Climatic Change, V 12, 1988, P 165-178 (14)

Cloudy Concerns, by R Monastersky

Science News, V 136, 12 Aug 1989, P 106-107, 110

Coal Technologies and Their Impact on the

Greenhouse Effect, by K M Sullivan

Energy Technologies for Reducing Emissions of Greenhouse Gases, Proceedings of an Expert's

Seminar, V 1, Paris, 12-14 April 1989, P 325- 338 (24)

Coherence Established Between Atmospheric Carbon

Dioxide and Global Temperature, by C Kuo,

C Lindberg, D J Thomson

Nature, V 343, 22 Feb 1990, P 709-714 (6)

Combustion of Refuse-Derived Fuel and Coal, by

G A Norton, A D Levine

Environmental Science Technology, V 23, N 7, 1989, P 774-783 (10)

Comment: On the Need for Validation of the Jones et. al. Temperature Trends with Respect to Urban Warming, by F B Wood Climatic Change, V 12, 1988, P 297-312 (16)

Comments on Chlorofluorocarbons and Stratospheric Ozone, by A A Lacis

Global Climate Change, Human and Natural

Influences, Chapter 9, 1989, P 163-170 (8) 
Conservation and Global Warming: A Problem in Biological Adaptation to Stress, by P A Parsons Ambio, V 18, N 6, 1989, P 322-325 (4)

Contribution of Energy Conservation and Alternative Energy Technologies to the Problems of Global Environment, by $\mathrm{N}$ Sasaki Energy Technologies for Reducing Emissions of Greenhouse Gases, Proceedings of an Expert's Seminar, V 2, Paris, 12-14 April 1989, P 187-195 (9)

Contribution of New Energy Supply, Transformation and Utilization Technologies in the Mitigation of Greenhouse Gases, by P Hostgaard-Jensen Energy Technologies For Reducing Emissions of Greenhouse Gases, Proceedings of an Expert's Seminar, V 2, Paris, 12-14 April 1989, P 277-286 (10)

Cost-Effectiveness Analysis: The Key for the Identification of Efficient Response Strategies to the Climate Issue Conceptional Approach and Modelling Tools, by A Voss, G Schmid Energy Technologies for Reducing Emissions of Greenhouse Gases, Proceedings of an Expert's Seminar, V 2, Paris, 12-14 April 1989, P 69-82 (14)

$\mathrm{CO}_{2}$ and Climate: A Missing Feedback? by

J F B Mitchell, C A Senior, W J Ingram Nature, V 341, N 6238, 14 Sept 1989, P 132-134 (3)

$\mathrm{CO}_{2}$ and the Greenhouse Effect: Actions and Strategies of German Hard Coal Mining Industry, by G Zimmermeyer, F H Esser Energy Technologies for Reducing Emissions of Greenhouse Gases, Proceeding of an Expert's Seminar, V 1, Paris, 12-14 April 1989, P 295-323 (29)

$\mathrm{CO}_{2}$ Emissions in the Last Decade and Energy Consumption in Belgium - Elements of $\mathrm{CO}_{2}$ Control Strategies (Including the Economics of Technologies for $\mathrm{CO}_{2}$ Recovery From Coal and Natural Gas Power Plants), by W J Hecq Energy Technologies for Reducing Emissions of Greenhouse Gases, Proceedings of an Expert's Seminar, V 1, Paris, 12-14 April 1989, P 405 (1)

$\mathrm{CO}_{2}$ Induced Climate Change in Ontario:

Interdependencies and Resource Strategies Climate Change Digest, CCD 88-09, 1988 (15)

Decarbonating Energy Systems: The Potential for Reducing $\mathrm{CO}_{2}$ Emissions Through Reduced Energy Intensity in Canada, by J B Robinson Energy Studies Review

Developing Country Energy Strategies, An Overview of the Climate Implications of Energy Strategies, by I W Mintzer Coping With Climate Change, Proceedings, Second North American Conference On Preparing For Climate Change: A Cooperative Approach, The Climate Institute, Washington, DC, June 1989, P 654-659 (6)

Developing Policies for Responding to Climate Change, by J Jaeger

The Challenge of Global Warming, Chapter 7, 1989, P 96-109 (14)
Development of Climatic Scenarios: A. From General Circulation Models, by W Bach

The Impact of Climatic Variations on Agriculture, V 1: Assessments in Cool Temperate and Cold Regions, Section 1, 1990, P 125-157 (33)

Development of Climatic Scenarios: B. Background to the Instrumental Record, by J Jager

The Impact of Climatic Variations on Agriculture, V 1: Assessments in Cool Temperate and Cold Regions, Section 4, 1990, P 159-181 (23)

Development of the Climate Scenarios, by M Yoshino The Impact of Climatic Variations on Agriculture, V 1: Assessments in Cool Temperate and Cold Regions, Part 6, Section 2, 1990, p 751-772 (22)

Directions in Advanced Reactor Technology, by M W Golay

Coping With Climate Change, Proceedings, Second North American Conference On Preparing For Climate Change: A Cooperative Approach, The Climate Institute, Washington, DC, June 1989, P 627-633 (7)

Do Large-Area-Average Temperature Series Have an Urban Warming Bias, by T M L Wigley, P D Jones Climatic Change, V 12, 1988, P 313-319 (7)

Economic Perspectives on the Impact of Climate Variability and Change: A Summary Report, by

P Timmerman, A P Grima Climate Change Digest, CCD 88-04, 1988 (10)

Ecopolitics in the Global, by W B Wood, G J Demko, P Mofson Environment, V 31, N 7, Sept 1989, P 12-17, 32-34 (9)

Effects of CFC Substitute, by K Shine Nature, V 344, 5 April 1990, P 492-493 (2)

Effects of Climatic Change on Water Supplies in the Western United States, by R R Ravelle, P E Waggoner The Challenge of Global Warming, Chapter 11, 1989, P 151-160 (10)

Effects of Global Warming on Biological Diversity, by R L Peters

The Challenge of Global Warming, Chapter 6, 1989, P 82-95 (14)

Effects of Global Warming on International Treaty Obligations Relating to Water Rights, by J M Strock Coping With Climate Change, Proceedings, Second North American Conference On Preparing For Climate Change: A Cooperative Approach, The Climate Institute, Washington, DC, June 1989, P 682-685 (4)

Effects on Lake Erie Water Quality, by A F Blumberg, D M DiToro

Report of the First US - Canada Symposium on Impacts of Climate Change on the Great Lakes Basin, National Climate Program Office, Canadian Climate Centre, US Environmental Protection Agency, Midwestern Climate Center, Oak Brook, Illinois, 27-29 Sept 1988, P 176 (1) 
Electricity Supply and Demand in Ontario, by

O T Melo

Report of the First US - Canada Symposium on Impacts of Climate Change on the Great Lakes Basin, National Climate Program Office, Canadian Climate Centre, US Environmental Protection Agency, Midwestern Climate Center, Oak Brook, Illinois, 27-29 Sept 1988, P 134-143 (10)

Emergency Preparedness to Address Climate Change, by S D Oaks

Coping With Climate Change, Proceedings, Second North American Conference On Preparing For Climate Change: A Cooperative Approach, The Climate Institute, Washington, DC, June 1989, P 377-381 (5)

Emission Control and Reduction, by J A Laurmann Climatic Change, V 15, 1989, P 271-298 (28)

Energy and Technology Options for Action on the Greenhouse Effect: A Decision Analysis Framework, by S Watson, R Bidwell, L Butterwick

Energy Technologies For Reducing Emissions of Greenhouse Gases, Proceedings of an Expert's Seminar, V 2, Paris, 12-14 April 1989,

P 543-552 (10)

Energy Efficiency and Global Warming, by A J Streb Energy Technologies For Reducing Emissions of Greenhouse Gases, Proceedings of an Expert's Seminar, V 1, Paris, 12-14 April 1989, P 87-113

Energy Efficiency: A New Agenda, by W U Chandler, H S Geller, M R Ledbetter

Coping With Climate Change, Proceedings, Second North American Conference on Preparing For Climate Change: A Cooperative Approach, The Climate Institute, Washington, DC, June 1989, P 589-594 (6)

Energy Technologies for the Use of Natural Gas to Reduce $\mathrm{CO}_{2}$ Emissions Including Gas Reburn

Technology for Coal Firing, by R Pfeiffer

Energy Technologies for Reducing Emissions of Greenhouse Gases, Proceedings of an Expert's Seminar, V 1, Paris, 12-14 April 1989, P 361-375 (15)

Energy Technology Options for Climate Warming: Preliminary Results, by P Schwengels Energy Technologies for Reducing Emissions of Greenhouse Gases, Proceedings of an Expert's Seminar, V 1, Paris, 12-14 April 1989, P 3-19 (17)

Energy-Related Carbon Dioxide Emissions in Alberta 1988-2005

Alberta Department of Energy, May 1990 (39)

Energy, People, and Industrialization, by A B Lovins Energy Technologies For Reducing Emissions of Greenhouse Gases, Proceedings of an Expert's Seminar, V 2, Paris, 12-14 April 1989, P 301-326 (26)

Environmental Challenge: Technological Response, by R M White, S R Rod

Environmental Science Technology, V 24, N 4, 1990, P 460-464 (5)
Environmental Effects of Carbon Dioxide and Other

Trace Gases, by $\mathrm{R} M$ Perhac

81st Annual Meeting of APCA, Dallas, 19-24

June, 1988. P 2- 19 (19)

Environmental Emissions from Energy Technology

Systems: The Total Fuel Cycle, by R L San Martin Energy Technologies for Reducing Emissions of Greenhouse Gases, Proceedings of an Expert's Seminar, V 1, Paris, 12-14 April 1989, P 255-271 (17)

Environmental Imperatives, by J Porritt Ozone Depletion: Health and Environmental Consequences, Chapter 18, 1989, P 243-249 (7)

EPA's Plan for Cooling the Global Greenhouse, by E Marshall

Science, V 243, 24 March 1989, P 1544-1545 (2)

Escaping the Heat Trap!

The Changing Atmosphere: Implications for Global Security, Proceedings, Secretariat of the World Meteorological Organization, Toronto, 27-30 June 1988, P 429-433 (5)

Estimated Annual Regime of Energy-Balance Components, Evapotranspiration and Soil Moisture for a Drainage Basin in the Case of a $\mathrm{CO}_{2}$ Doubling, by F Bultot, G L Dupriez, D Gellens Climatic Change, V 12, 1988, P 39-56 (18)

Estimating Effects of Climatic Change on Agriculture in Saskatchewan, Canada, by R B Stewart, K H Jones, E E Wheaton, G D V Williams

Climate Change Digest, CCD 88-06, 1988 (12)

Eustatic Sea Level and $\mathrm{CO}_{2}$, by A Frei,

M C MacCracken, M I Hoffert

Northeastern Environmental Science, V 7, N 1, 1988, P 91-96 (6)

Evapotranspiration in a Greenhouse-Warmed World: A Review and a Simulation, by N J Rosenberg,

M S McKenney, P Martin

Agriculture For Meteorology, 47, 1989, P 303-320 (18)

Evidence For a Decline in the Atmospheric Accumulation Rate of CHCIF2(CFC-22), by

C P Rinsland, D W Johnson, A Goldman, J S Levine Nature, V 337, N 6207, 9 Feb 1989, P 535-537 (3)

Exploring Acid Gas Emission Reductions in the Province of Quebec via Markal-Quebec, by C Berger, A Haurie, E Lessard, R Loulou, J-P Waaub GERAD, Montreal, 1990 (32)

Exploring the Implications of Climatic Change for the Boreal Forest and Forestry Economics of Western Canada, by E E Wheaton, T Singh, R Dempster, K O Higginbotham, J P Thorpe, G C Van Kooten, J S Taylor

Climate Change Digest, CCD 89-02, 1989

Factoring Climate Change into Corporate Planning: Introduction to Panel Discussion, by R Strelow Coping With Climate Change, Proceedings, Second North American Conference On Preparing For Climate Change: A Cooperative Approach, The Climate Institute, Washington, DC, June 1989, P 385-388 (4) 
Factors Affecting Biological Methane Production, by

C C Delwiche

Coping With Climate Change, Proceedings, Second

North American Conference on Preparing for

Climate Change: A Cooperative Approach, The

Climate Institute, Washington, DC, June 1989,

P 214-218 (5)

Felled Trees Deal Double Blow to Global Warming, by

F Pearce

New Scientist, 16 Sept 1989 P 25 (1)

Food Security in the Changing Global Climate by,

S K Sinha, N H Rao, M S Swaminathan

The Changing Atmosphere: Implications for Global Security Proceeding, Secretariat of the World Meteorological Organization, Toronto,

27-30 June 1988, P 167-191 (25)

Forests and Atmospheric Change, by J S Maini The Changing Atmosphere: Implications for Global Security Proceeding, Secretariat of the World Meteorological Organization, Toronto, 27- 30 June 1988, P 193-209 (17)

Forests: A Tool to Moderate Global Warming? by R E Sedjo

Environment, V 31, N 1, Jan/Feb 1989, P 14-20 (7)

Fossil-Fuelled Civilization and the Atmosphere: How

Much Should We Worry? by V Smil

Resources and World Development, 1987, P 363-375 (13)

From "Climate Changes and US Water Resources": A Brief Summary and the Recommendations, by

P E Waggoner

Coping With Climate Change, Proceedings, Second North American Conference on Preparing For Climate Change: A Cooperative Approach, The Climate Institute, Washington, DC, June 1989 , P 320-326 (7)

Fuel Reformulations, Alternatives Cover Broad

Spectrum, by R A Corbett

Oil \& Gas Journal, 18 June 1990,

P 42-43, 47-50 (6)

Future Changes in Climate Variability, by D Rind Coping With Climate Change, Proceedings, Second North American Conference on Preparing for Climate Change: A Cooperative Approach, The Climate Institute, Washington, DC, June 1989 , P 111-114 (4)

Gas Taps its Natural Flare, by A Melvin New Scientist, 7 Oct 1989, P 59-61 (3)

GCM Response to $\mathrm{CO}_{2}$ Doubling: The Effect of Cloud, Ice, and Snow on Northern and Southern High

Latitude Regions, by S Goldenberg, W C Wang Symposium on the Role of Climate in Atmosphere Chemistry and Global Climate, American Meteorology Society, Anaheim, California, 30 Jan-3 Feb, 1989, P 71-75 (5)
GLERL Activities: Abstract, by F H Quinn Report of the First US - Canada Symposium on Impacts of Climate Change on the Great Lakes Basin, National Climate Program Office, Canadian Climate Centre, US Environmental Protection Agency, Midwestern Climate Center, Oak Brook, Illinois, 27-29 Sept 1988, P 174-175 (2)

Global Change and the Record of the Past, by

B H Luckman

Geophysics, V 3, 1989, P 1-8 (8)

Global Climate Change and US Agriculture, by R M Adams, C Rosenzweig, R M Peart, J T Ritchie, B A McCarl, J D Glyer, R B Curry, J W Jones, K J Boote, L H Allen Jr Nature, V 345, 17 May 1990, P 219-224 (6)

Global Climate Change-Implications for the Tennessee Valley Authority Reservoir System, by B A Miller, W G Brock

Coping With Climate Change, Proceedings, Second North American Conference On Preparing For Climate Change: A Cooperative Approach, The Climate Institute, Washington, DC, June 1989, P 493-500 (8)

Global Climate Change, by W W Kellog Climate Change and Water Research: Research Needs and Opportunities, Proceedings, 1988 Annual Meeting Universities Council on Water Resources Inc, Washington State University, University Idaho, Coeur d'Alene, Idaho, 5-8 July 1988, P 17-30 (14)

Global Climatic Change-What it Could Mean for Prairie Agriculture, by E E Wheaton Global Climatic Change Public Seminars, University of Saskatchewan, 1989, P 105-114 (10)

Global Energy Strategies and Climate Change, by

W U Chandler

Coping With Climate Change, Proceedings, Second North American Conference On Preparing For Climate Change: A Cooperative Approach, The Climate Institute, Washington, DC, June 1989 P 634-653 (20)

Global Greenhouse Warming: Energy and

Development, by G H Kats

Energy Technologies For Reducing Emissions of Greenhouse Gases, Proceedings of an Expert's Seminar, V 2, Paris, 12-14 April 1989, P 515-542 (28)

Global Greenhouse Warming: Role of the Power Generation Sector and Mitigation Strategies, by I M Torrens

Energy Technologies for Reducing Emissions of Greenhouse Gases, Proceedings of an Expert's Seminar, V 2, Paris, 12-14 April 1989, P 15-52 (38)

Global Marine Temperature Variation and the Solar Magnetic Cycle, by N E Newell, R E Newell, J Hsiung, $\mathrm{Z} \mathrm{Wu}$

Geophysical Research Letters, V 16, N 4, April 1989, P 311-314 (4)

Global Smog: Newest Greenhouse Projection, by J Raloff

Science News, V 135, April 1989, P 262-263 (2) 
Global Warming and Changing Weather Patterns, by

E E Wheaton

Accent 90, Calgary, 27-28 Feb 1990, P 6.1-6.8 (8)

Global Warming and Regional Climatic Trends in

Agricultural Areas, by F Kogan

6th Conference on Applied Climatology, Charleston, March 1989, P J16-J17 (2)

Global Warming and Rising Sea Levels: The Policy

Implications, by G P Hekstra

The Ecologist, V 19, N 1, 1989, P 4-15 (12)

Global Warming and the Coastal Zone, by J E Bardach Climatic Change, V 15, 1989, P 117-150 (34)

Global Warming and the Greenhouse Effect: How Hot is too Hot? Radian Report, US, Oct 1989 (3)

Global Warming, Acid Rain, and Ozone Depletion, by

R Cicerone

The Challenge of Global Warming, Chapter 15, 1989, P 231-238 (9)

Global Warming: Policies for Amelioration, by

R Milko

Library of Parliament, Research Branch,

Nov 1989 (44)

Global Warming: The Issue, Impact, Responses, by

D E Abrahamson

The Challenge of Global Warming, Chapter 1, 1989 , P 3-34 (32)

Global Warming: The Need for Objectivity, by $\mathrm{T}$ Ball Bio-Joule, Jan 1990, P 5-7 (3)

Government Strategies to Limit Buildup of Greenhouse

Gases, by D J Bardin

Coping With Climate Change, Proceedings, Second North American Conference On Preparing For Climate Change: A Cooperative Approach, The Climate Institute, Washington, DC, June 1989, P 561-569 (9)

Greater Global Warming Revealed by Satellite-Derived

Sea-Surface-Temperature Trends, by A E Strong

Nature, V 338, N 6217, 20 April 1989,

P 642-645 (4)

Green Diplomacy

The Economist, 16 June 1990, P 17-18, 20 (3)

Greener Cars May Warm the World, by R Gould, $\mathrm{J}$ Gribbin

New Scientist, 20 May 1989, P 34 (1)

Greenhouse Economics

The Economist, 7 July 1990, P 21-22, 24 (3)

Greenhouse Effect, Tropical Rain Forests and

Environmental Colonialism, by A A Moghissi Environmental International, V 14, 1988, P 385-386 (2)

Greenhouse Effects and Impacts on Physical Systems, by J Firor

The Challenge of Global Warming, Chapter 8, 1989, P 113-122 (10)
Greenhouse Gas Emissions: The Energy Dimension White House Conference on Science and Economics Research to Global Change, 17-18 April 1990 (230)

Greenhouse Gases Released to the Atmosphere From Deforestation For Farmland, by R A Houghton Coping With Climate Change, Proceeding Second North American Conference on Preparing For Climate Change: A Cooperative Approach, The Climate Institute, Washington, DC, June 1989, P 219-223 (5)

Greenhouse Gases, Climate Change, and US Forest Markets, by J L Regens, F W Cubbage, D G Hodges Environment, V 31, N 4, May 1989, P 4-5, 41 (3)

Greenhouse Guessing: When Should Scientists Speak Out? by A H Sellers Climatic Change, V 16, 1990, P 5-8 (4)

Greenhouse Impact in Fennoscandia-Preliminary Findings of a European Workshop on the Effects of Climate Change, by M M Boer, E A Koster, H Lundberg Ambio, V 19, N 1, Feb 1990, P 2-10 (9)

Greenhouse Implications of Energy Policies of Multilateral Development Institutions, by D A Wirth Coping With Climate Change, Proceedings, Second North American Conference On Preparing For Climate Change: A Cooperative Approach, The Climate Institute, Washington, DC, June 1989, P 660-665

Greenhouse Skeptic Out in the Cold, by R A Kerr Science, V 246, Dec 1989, P 1118-1119 (2)

Hansen vs. the World on the Greenhouse Threat, by R Kerr

Science, V 244, 2 June 1989, P 1041-1043

Health Effects Issues Associated With Regional and Global Air Pollution Problems, by L D Grant The Changing Atmosphere: Implications for Global Security Proceedings, Secretariat of the World Meteorological Organization, Toronto, 27-30 June 1988, P 243-270 (28)

Historical Climate Records in China and Reconstruction of Past Climates, by $\mathrm{J}$ Zhang, T J Crowley Journal of Climate, V 2, N 8, 1989, P 833-849 (17)

How Fast Can Trees Migrate? by L Roberts Science, N 243, 10 Feb 1989, P 735-737 (3)

How to Solve the $\mathrm{CO}_{2}$ Problem Without Tears, by C Marchetti

Energy Technologies for Reducing Emissions of Greenhouse Gases, Proceedings of an Expert's Seminar, V 1, Paris, 12-14 April 1989, P 161- 191 (31) 
Human Development and Carbon Dioxide Emissions: The Current Picture and the Long-Term Prospects, by J Darmstadter, J Edmonds

Greenhouse Warming: Abatement and Adaptation, Proceedings of a Workshop, National Oceanic and Atmospheric Administration, US Department of Energy, US Department of Agriculture, US Environmental Protection Agency, International Federal Institute for Advanced Study, Resources for the Future, Washington, DC, 14-15 June 1988, P 35-51 (17)

Human Dimensions of Global Change: Toward a Research Agenda, by I Burton

Greenhouse Warming: Abatement and Adaptation, Proceedings of a Workshop, NOAA, US Department of Energy, US Department of Agriculture, US Environmental Protection Agency, International Federal Institute for Advanced Study, Resources for the Future, Washington, DC, 14-15 June 1988, P 159- 165 (7)

Hydrometeorlogical Changes Due to Increasing Atmospheric $\mathrm{CO}_{2}$ and Associated Trace Gases, by J G Lockwood

Progress in Physical Greography, V 13, N 3, 1989, P 115-127 (13)

Impact of Climate Warming on Residential Consumption of Natural Gas in Canada, by

B F Findlay, L Spicer

Climatological Bulletin, V 22(2), 1988, P 3-13 (11)

Impact of Energy Use on Global Climate Change, by G J MacDonald

Energy Technology, V 15, 1988, P 140-153 (14)

Impact of Species Selection and $\mathrm{CO}_{2}$ Concentration on Global Photosynthesis, by M N Sivak

Energy Technologies for Reducing Emissions of Greenhouse Gases, Proceedings of an Expert's Seminar, V 1, Paris, 12-14 April 1989, P 273-280 (8)

Impact on Forestry in Central Canada, by S C Zoltai Report of the First US - Canada Symposium on Impacts of Climate Change on the Great Lakes Basin, National Climate Program Office, Canadian Climate Centre, US Environmental Protection Agency, Midwestern Climate Center, Oak Brook, Illinois, 27-29 Sept 1988, P 185-187 (3)

Impacts of Carbon Dioxide Warming on Climate and Man in the Semi-Arid Tropics, by J A Mabbutt Climatic Change, V 15, 1989, P 191-221 (31)

Impacts of Climate Change on California Water Resources, by J B Knox, R W Buddemeier Coping With Climate Change, Proceedings, Second North American Conference On Preparing For Climate Change: A Cooperative Approach, The Climate Institute, Washington, DC, June 1989, P 469-473 (5)

Impacts of Climate Change on the Transport of Agricultural Chemicals Across the USA Great Plains and Central Prairie, by E J Cooter, H L Johnson, R J Sladewski

6th Conference on Applied Climatology,

Charleston, March 1989, P J18-J25 (8)
Impacts of Climatic Warming on Residential

Consumption of Natural Gas in Canada, by

B F Findlay, L Spicer

Climatological Bulletin, V 22(2), 1988, P 3-13 (11)

Impacts of Global Climate Change on Metropolitan Infrastructure, by $\mathrm{T} \mathrm{R}$ Miller

Coping With Climate Change, Proceedings, Second North American Conference On Preparing For Climate Change: A Cooperative Approach, The Climate Institute, Washington, DC, June 1989 P 366-376 (11)

Impacts on Electricity Generation in New York State, by $\mathrm{R} D$ Crissman

Report of the First US - Canada Symposium on Impacts of Climate Change on the Great Lakes Basin, National Climate Program Office, Canadian Climate Centre, US Environmental Protection Agency, Midwestern Climate Center, Oak Brook, Illinois, 27-29 Sept 1988, P 109-118 (10)

Impacts on Great Lakes Shipping, by G J Ryan Report of the First US - Canada Symposium on Impacts of Climate Change on the Great Lakes Basin, National Climate Program Office, Canadian Climate Centre, US Environmental Protection Agency, Midwestern Climate Center, Oak Brook, Illinois, 27-29 Sept 1988, P 122-125 (4)

Implications for Caribbean Societies of Climate Change, Sea-level Rise and Shifts in Storm Patterns, by $\mathrm{O}$ E Granger

Coping With Climate Change, Proceedings, Second North American Conference On Preparing For Climate Change: A Cooperative Approach, The Climate Institute, Washington, DC, June 1989, P 422-431 (10)

Implications of a Changing Atmosphere on Water Resources, by J Nemec

The Changing Atmosphere: Implications for Global Security Proceedings, Secretariat of the World Meteorological Organization, Toronto, 27-30 June 1988, P 211-224 (14)

Implications of a Global Climatic Warming for Agriculture: A Review and Appraisal, by B Smit, L Ludlow, M Brklacich Journal of Environmental Quality, V 17, N 4, 1988, P 519-527 (9)

Implications of Climate Change for Agriculture and Land Use, by B Smit

Report of the First US - Canada Symposium on Impacts of Climate Change on the Great Lakes Basin, National Climate Program Office, Canadian Climate Centre, US Environmental Protection Agency, Midwestern Climate Center, Oak Brook, Illinois, 27-29 Sept 1988, P 188-193 (6)

Implications of Climate Change for Downhill Skiing in Quebec

Climate Change Digest, CCD 88-03, 1988

Implications of Climate Change for Small Coastal Communities in Atlantic Canada, by P Stokoe, M LeBlanc, C Larson, M Manzer, P Manuel Climate Change Digest, V 90, N 1, 1990 (18) 
Implications of Climate Change for the Insurance Industry, by D G Friedman

Coping With Climate Change, Proceedings, Second

North American Conference On Preparing For

Climate Change: A Cooperative Approach, The

Climate Institute, Washington, DC, June 1989, P 389-400 (12)

Implications of Climate Changes in the Wider

Caribbean Region: An Overview, by G A Maul

Coping With Climate Change, Proceedings, Second

North American Conference On Preparing For

Climate Change: A Cooperative Approach, The

Climate Institute, Washington, DC, June 1989,

P 432-458 (27)

Implications of Climatic Change for Prince Albert

National Park, Saskatchewan, by G Wall

Climate Change Digest, CCD 89-03, 1989 (11)

Implications of Climatic Change for Tourism and

Recreation in Ontario, by G Wall

Climate Change Digest, CCD 88-05, 1988 (19)

Incentives for CFC Substitutes: Lessons for Other

Greenhouse Gases, by A S Miller

Coping With Climate Change, Proceedings, Second

North American Conference On Preparing For

Climate Change: A Cooperative Approach, The

Climate Institute, Washington, DC, June 1989,

P 547-551 (5)

Influence of Nitrogen Fertilization on Methane Uptake in Temperate Forest Soils, by P A Steudler,

R D Bowden, J M Melillo, J D Aber

Nature V 341, N 6240, 28 Sept 1989, P 314-316 (3)

International Co-operation in Atmospheric Sciences and the Changing Atmosphere, by G O P Obasi The Changing Atmosphere: Implications for Global Security Proceedings, Secretariat of the World Meteorological Organization, Toronto, 27-30 June 1988, P 140-156 (17)

Is Canadian Cloudiness Increasing? by $\mathrm{K}$ McGuffie, A Henderson- Sellers Atmosphere-Ocean V 26(4), 1988, P 608-633 (26)

Jumping the Greenhouse Gun, by J Maddox Nature, V 334, July 1988, P 9 (1)

Kinetics of Radical Reactions in the Atmospheric Oxidation of $\mathrm{CH} 4$, by A R Ravishankara Annual Review of Physics and Chemistry, V 39, 1988, P 367-394 (28)

Lags in Vegetation Response to Greenhouse Warming, by M B Davis Climatic Change, V 15, 1989, P 75-82 (8)

Land Surface Hydrology Parameterization for Atmospheric General Circulation Models Including Subgrid Scale Variability, by D Entekhabi, P S Eagleson

Journal of Climate, V 2, Aug 1989, P 816-831 (16)
Likely Effects of Climate Change Scenarios on Agriculture of the USA, by L H Allen Jr, R M Peart, J W Jones, R B Curry, K J Boote

Coping With Climate Change, Proceedings, Second North American Conference On Preparing For Climate Change: A Cooperative Approach, The Climate Institute, Washington, DC, June 1989, P 186-191 (6)

Likely Effects of Climate on Water Quality, by H D Jacoby

Coping With Climate Change, Proceedings, Second North American Confirence On Preparing For Climate Change: A Cooperative Approach, The Climate Institute, Washington, DC, June 1989, P 348- 352 (5)

Likely Effects of Global Climate Change on Fish Associations of the Great Lakes, by $\mathrm{H} \mathrm{A}$ Regier, J J Magnuson, B J Shutter, D K Hill, J A Holmes,

\section{$J$ D Meisner}

Coping With Climate Change, Proceedings, Second North American Conference On Preparing For Climate Change: A Cooperative Approach, The Climate Institute, Washington, DC, June 1989, P 234-255 (22)

Likely Impact of Climate Change on Canadian Agriculture, by B Smit

Coping With Climate Change, Proceedings, Second North American Conference on Preparing For Climate Change: A Cooperative Approach, The Climate Institute, Washington, DC, June 1989, P 197-202 (6)

Linkages Between Climate Protection and Air Quality Strategies, by W R Moomaw Coping With Climate Change, Proceedings, Second North American Conference On Preparing For Climate Change: A Cooperative Approach, The Climate Institute, Washington, DC, June 1989, P 229- 230 (2)

Living in the Greenhouse

The Economist, 11 March 1989, P 87-90 (4)

Long Term Climate Prediction: PM's Speech, by M Thatcher

British Information Services, 1990 (4)

Looking for Mr. Greenhouse, by R Monastersky Science News, V 135, 8 April 1989,

P 216-217, 221 (3)

Major Volcanic Eruptions and Climate: A Critical Evaluation, by C F Mass, D A Portman Journal of Climate, V 2, N 6, 1989, P 566-593

Managing Atmospheric $\mathrm{CO}_{2}$, by J Edmonds Climatic Change, V 15, 1989, P 339-341

Managing Atmospheric $\mathrm{CO}_{2}$, by L D D Harvey Climatic Change, V 15, 1989, P 343-381 (49)

Managing Planet Earth, by W C Clark Scientific American, V 261, N3, Sept 1989, P 46-57 (12) 
Marsh Loss and Shore Erosion with Sea-Level Rise in Chesapeake Bay, by M S Kearney, J C Stevenson Coping With Climate Change, Proceedings, Second North American Conference On Preparing For Climate Change: A Cooperative Approach, The Climate Institute, Washington, DC, June 1989, P 506-508 (3)

Measurement and Prediction of Global Warming, by T M L Wigley

Ozone Depletion: Health and Environmental Consequences, Chapter 8, 1989, P 85-97 (13)

Methane in the Atmosphere, by $\mathrm{R} \mathrm{J}$ Cicerone Global Climate Change, Human and Natural Influences, Chapter 6, 1989, P 91-112 (22)

Methane Locked in Permafrost May Hold Key to Global Warming, by F Pearce New Scientist, 4 March 1989 P 28 (1)

Methane May Amplify Climate Change, by J Gribbin New Scientist, 2 June 1990, P 31 (1)

Methane, CFCs, and Other Greenhouse Gases, by

D R Blake

The Challenge of Global Warming, Chapter 17, 1989, P 248-255 (8)

Methane: The Hidden Greenhouse Gas, by F Pearce New Scientist, 6 May 1989, P 37-41 (4)

Mirrors to Halt Global Warming? by W Seifritz Nature, V 340, N 6235, 24 Aug 1989 P 603 (1)

Mission to Planet Earth Revisited, by T F Malone, R Corell

Environment, V 31, N3, April 1989, P 6-11, 31-35 (11)

Mitigating Climate Change: Strategies to Finance Retention of Tropical Forests, by A Qureshi Coping With Climate Change, Proceedings, Second North American Conference On Preparing For Climate Change: A Cooperative Approach, The Climate Institute, Washington, DC, June 1989, P 313-319 (7)

Model Calculations of the Relative Effects of CFCs and their Replacements on Global Warming, by

D A Fisher, C H Hales, W C Wang, M K W Ko, N D Sze

Nature, V 344, 5 April 1990, P 513-516 (4)

Model Calculations of the Relative Effects of CFCs and Their Replacements on Stratospheric Ozone, by D A Fisher, C H Hales, D L Filkin, M K W Ko, N D Sze, P S Connell, D J Wuebbles, I S A Isaksen, F Stordal

Nature, V 344, 5 April 1990, P 508-512 (5)

Modeling the Nutrient and Carbon Cycles of the North Atlantic 2. New Production, Particle Fluxes, $\mathrm{CO}_{2} \mathrm{Gas}$ Exchange, and the Role of Organic Nutrients, by R Schlitzer

Journal of Geophysical Research, V 94, N C9, 15 Sept 1989, P 12781-12794 (14)
Monitoring Concepts Useful in the Assessment of Climate Change Effects on US Fish and Wildlife Resources, by R P Breckenridge

Coping With Climate Change, Proceedings, Second North American Conference On Preparing For Climate Change: A Cooperative Approach, The Climate Institute, Washington, DC, June 1989, P 268-272 (5)

More Efficient Technologies and Fuel Switching: The Near-Term Prevention Strategy, by W Fulkerson, A M Perry, D B Reister

Coping With Climate Change, Proceedings, Second North American Conference On Preparing For Climate Change: A Cooperative Approach, The Climate Institute, Washington, DC, June 1989, P 570-583 (14)

Multi-Year Fluctuations of Temperature and Precipitation: The Gray Area of Climate Change, by T R Karl

Climatic Change, V 12, 1988, P 179-197 (19)

Natural Gas Select-Use Technologies: Opportunities for Emissions Reductions Using Natural Gas in Conjunction with Coal, by L Solsberg

Energy Technologies for Reducing Emissions of Greenhouse Gases, Proceedings of an Expert's Seminar, V 1, Paris, 12-14 April 1989, P 377- 395 (19)

Natural Gas: Clean Air Monitoring in the 1990s, by

B Vernon

Globe '90 International Conference, Vancouver, 21 March 1990 (15)

Natural Variability of the Climate System and Detection of the Greenhouse Effect, by T M L Wigley, S C B Raper

Nature, V 344, 22 March 1990, P 324-327 (4)

Nature Under Glass, by J R Udall

Sierra, July-Aug 1989, P 34-40 (7)

Near-Term Congressional Options for Responding to Global Climate Change, by W R Moomaw

The Challenge of Global Warming, Chapter 21, 1989, P 305-326 (22)

New Developments in Dutch Energy Conservation Measures and Energy Technology Options as a Result of the Discussion on the Greenhouse Problem, by A Zweering

Energy Technologies for Reducing Emissions of Greenhouse Gases, Proceedings of an Expert's Seminar, V 2, Paris, 12-14 April 1989, P 595-598 (4)

Nitrous Oxide Emissions From Fossil Fuel Combustion, by W P Linak, J A McSorley, R E Hall, J V Ryan, R K Srivastava, J O L Wendt, J B Mereb

Journal of Geophysical Research, V 95, N D6, 20 May 1990, P 7533-7541 (9)

North American Forests During Rapid Climate Change: Overview of Effects and Policy Response Options, by K Andrasko, J B Wells

Coping With Climate Change, Proceedings, Second North American Conference On Preparing For

Climate Change: A Cooperative Approach, The

Climate Institute, Washington, DC, June 1989, P 282-291 (10) 
North American Total Cloud Amount Variations This Century, by A H Sellers

Paleogeography, Palaeoclimatology, Paleoecology, N 75, 1989, P 175-194 (20)

Northern Hemisphere Temperature Trends: A Possible Greenhouse Gas Effect? by D J Karoly Geophysical Research Letters, V 16, N 5, May 1989, P 465-468 (4)

Observational Constraints on the Global Atmospheric $\mathrm{CO}_{2}$ Budget, by P P Tans, I Y Fung, T Takahashi Science V 247, 23 March 1990, P 1431-1438 (8)

Observed Climate Change, and the Greenhouse Effect, by D E Parker

Meteorological Magazine, N 118, 1989, P 128-131 (4)

Observed Increases in Greenhouse Gases and Predicted

Climatic Changes, by V Ramanathan

The Challenge of Global Warming, Chapter 16, 1989, P 239-247 (9)

Ocean Response to Greenhouse Warming, by U

Mikolajewicz, B D Santer, E Maier-Reimer Nature, V 345, 14 June 1990, P 589-593 (5)

Oceans: A Dynamic Reservoir for Carbon Dioxide, by

T Takahashi

Coping With Climate Change, Proceedings, Second

North American Conference on Preparing for Climate Change: A Cooperative Approach, The Climate Institute, Washington, DC, June 1989, P 136-141 (6)

On Coefficients for Determining Greenhouse Gas Emissions from Fossil Fuel Production and

Consumption, by M J Grubb

Energy Technologies for Reducing Emissions of Greenhouse Gases, Proceedings of an Expert's Seminar, V 1, Paris, 12-14 April 1989, P 537-555 (19)

On Setting Targets for Reduction of Greenhouse Gas Induced Climate Warming, by J A Laurmann Energy Technologies for Reducing Emissions of Greenhouse Gases, Proceedings of an Expert's Seminar, V 1, Paris, 12-14 April 1989, P 457-488 (32)

On the Detection of Greenhouse Warming, by

A R Solow, J M Broadus Climatic Change, V 15, 1989, P 449-453 (5)

On the Stability of Earth's Climate, by S B Idso Theoretical Applied Climatology, V 39, 1989, P 177-178 (2)

Optimisation of Energy Strategies for Power Generation in Relation to Global Climate Change, by

I J Graham-Bryce Energy Technologies for Reducing Emissions of Greenhouse Gases, Proceedings of an Expert's Seminar, V 2, Paris, 12-14 April 1989, P 159-171 (13)

Options for Constraining the Emissions of $\mathrm{CO}_{2}$ in Sweden, Including the Role of Forestry Biomass, by A Boeryd

Energy Technologies for Reducing Emissions of Greenhouse Gases, Proceedings of an Expert's Seminar, V 2, Paris, 12-14 April 1989, P 455-464 (10)
Our Changing Atmosphere: Energy Policies, Air Pollution and Global Warming, by I Mintzer The Changing Atmosphere: Implications for Global Security Proceedings, Secretariat of the World Meteorological Organization, Toronto, 2730 June 1988, P 117-138 (22)

Our Changing Climate, by B Eriksson,

$\mathrm{H}$ Alexandersson

Agriculture For Meteorology, V 50, 1990,

P 55-64 (10)

Our Last Chance for a National Energy Policy, by R Cavanagh, D Goldstein, R Watson

The Challenge of Global Warming, Chapter 19, 1989, P 270-290 (21)

Overview of the Potential Effects of Climate Change on Human Health, by J Longstreth

Coping With Climate Change, Proceedings, Second North American Conference On Preparing For Climate Change: A Cooperative Approach, The Climate Institute, Washington, DC, June 1989, P 142-146 (5)

Overview of the Potential Health Effects Associated With Ozone Depletion, by J Longstreth Coping With Climate Change, Proceedings, Second North American Conference On Preparing For Climate Change: A Cooperative Approach, The Climate Institute, Washington, DC, June 1989, P 163-167 (5)

Ozone and the Greenhouse Effect, by H Oeschger, H U Dutsch

Nature, V 339, N 6219, 4 May 1989, P 19 (1)

Ozone Crisis: The Case Against Chlorofluorocarbons, by B Brune

Weatherwise, V 43, N 3, June 1990, P 136-143 (8)

Ozone Loss Will Hit Health and Food, Says UN Study, by J Sinclair

New Scientist, 3 Feb 1990, P 27 (1)

Planning for Climate Variability and Uncertainty, by

M W Mugler, E Z Stakhiv, H J Cortner, M Rubino Coping With Climate Change, Proceedings, Second North American Conference On Preparing For Climate Change: A Cooperative Approach, The Climate Institute, Washington, DC, June 1989, P 382-384 (3)

Planning For Our Common Future--Options For Actions, by M W Holdgate

Environment, V 31, N 8, Oct 1989 ,

P 14-17, 38-41 (8)

Plants in the Greenhouse World, by I Woodward New Scientist, 6 May 1989, P 1-4 (4)

Policy Implications of Climate Change, by E Z Stakhiv, J R Hanchey

Report of the First US - Canada Symposium on Impacts of Climate Change on the Great Lakes Basin, National Climate Program Office, Canadian Climate Centre, US Environmental Protection Agency, Midwestern Climate Center, Oak Brook, Illinois, 27-29 Sept 1988, P 162-173 (12)

Possible Climate Change Due to $\mathrm{SO}_{2}$-Derived Cloud Condensation Nuclei, by T M L Wigley Nature, V 339, N 6223, 1 June 1989, P 365-367 (3) 
Potential Climate Change Effects on Irrigated Agriculture in California, by D J Dudek

Coping With Climate Change, Proceedings, Second North American Conference on Preparing For Climate Change: A Cooperative Approach, The Climate Institute, Washington, DC, June 1989, P 479-483 (5)

Potential Coastal Effects of Climate Change in the Caribbean, by F J Gable, D G Aubrey

Coping With Climate Change, Proceedings, Second North American Conference on Preparing For Climate Change: A Cooperative Approach, The Climate Institute, Washington, DC, June 1989, P 417-421 (5)

Potential Economic and Political Problems of Climate Change, by D Totten, E Dowdeswell, L Botts Report of the First US - Canada Symposium on Impacts of Climate Change on the Great Lakes Basin, National Climate Program Office, Canadian Climate Centre, US Environmental Protection Agency, Midwestern Climate Center, Oak Brook, Illinois, 27-29 Sept 1988, P 87-97 (11)

Potential Effects for Tourism and Recreation in Ontario, by G Wall

Report of the First US - Canada Symposium on Impacts of Climate Change on the Great Lakes Basin, National Climate Program Office, Canadian Climate Centre, US Environmental Protection Agency, Midwestern Climate Center, Oak Brook, Illinois, 27-29 Sept 1988, P 148-156 (9)

Potential Effects of Climate Change on Chesapeake Bay Animals and Fisheries, by V S Kennedy Coping With Climate Change, Proceedings, Second North American Conference on Preparing For Climate Change: A Cooperative Approach, The Climate Institute, Washington, DC, June 1989, P 509-513 (5)

Potential Effects of Halons on Stratospheric $\mathrm{O}_{3}$ Based on the Montreal Protocol, by J C McConnell, E M J Templeton, G S Henderson, W F J Evans

Atmosphere-Ocean, V 28(2), 1990, P 177-188 (12)

Potential Effects on Great Lakes Fishes, by

J J Magnuson

Report of the First US - Canada Symposium on Impacts of Climate Change on the Great Lakes Basin, National Climate Program Office, Canadian Climate Centre, US Environmental Protection Agency, Midwestern Climate Center, Oak Brook, Illinois, 27-29 Sept 1988 (1)

Potencial Energy Uses and Greenhouse Implications of Hydrogen, by P Hoffman

Coping With Climate Change, Proceedings, Second North American Conference On Preparing For Climate Change: A Cooperative Approach, The Climate Institute, Washington, DC, June 1989, P 600-606 (7)

Potential Evapotranspiration and the Likelihood of Future Drought, by D Rind, R Goldberg, J Hansen, C Rosenzweig, R Ruedy Journal of Geophysical Research, V 95, N D7, 20 June, 1990, P 9983-10004 (22)
Potential Fossil Energy-Related Technology Options to Reduce Greenhouse Gas Emissions, by R Kane,

D W South

Energy Technologies For Reducing Emissions of Greenhouse Gases, Proceedings of an Expert's Seminar, V 1, Paris, 12-14 April 1989, P 35-58

Potential Impact of Global Warming: Changes in Mortality From Extreme Heat and Cold, by

L S Kalkstein

Coping With Climate Change, Proceedings, Second

North American Conference on Preparing For

Climate Change: A Cooperative Approach, The

Climate Institute, Washington, DC, June 1989,

P 153-157 (5)

Potential Invasion of the Great Lakes by Fish Species Associated With Climatic Warming, by $\mathrm{N}$ E Mandrak Journal of Great Lakes Research, V 15(2), 1989, P 306-316(11)

Potential Shifts of Monsoon Patterns Associated with Climate Warming, by E M Rasmusson Coping With Climate Change, Proceedings, Second North American Conference On Preparing For Climate Change: A Cooperative Approach, The Climate Institute, Washington, DC, June 1989, P 120-124 (5)

Potential Strategies for Adapting to Greenhouse Warming: Perspectives from the Developing World, by N S Jodha

Greenhouse Warming: Abatement and Adaptation, Proceedings of a Workshop, National Oceanic and Atmospheric Administration, US Department of Energy, US Department of Agriculture, US Environmental Protection Agency, International Federal Institute for Advanced Study, Resources for the Future, Washington, DC, 14-15 June 1988, P 147-158 (12)

Preliminary Study of the Possible Impacts of a One Metre Rise in Sea Level at Charlottetown, Prince Edward Island Climate Change Digest, CCD 88-02, 1988 (11)

Preparing for Climate Change in the Great Lakes: Introduction to Panel Discussion, by S J Cohen Coping With Climate Change, Proceedings, Second North American Conference On Preparing For Climate Change: A Cooperative Approach, The Climate Institute, Washington, DC, June 1989, P 526- 528 (3)

Preparing Policymakers to Address the Problem of Climate Change, by G Watson Coping With Climate Change, Proceedings, Second North American Conference On Preparing For Climate Change: A Cooperative Approach, The Climate Institute, Washington, DC, June 1989, P 514-515 (2)

Present and Future Trends in Environmental Protection, by Y Kasahara Coping With Climate Change, Proceedings, World Petroleum Congress, V 12, N 1, 1988, P 171-182 (12)

Present State of Knowledge of the Ozone Layer, by R J Watson

Ozone Depletion: Health and Environmental Consequences, Chapter 5, 1989, P 43-58 (16) 
Present Status and Future Prospect of Energy Utilization Technology in Japan for Greenhouse Gas Mitigation, by T Kashiwagi

Energy Technologies for Reducing Emissions of Greenhouse Gases, Proceedings of an Expert's Seminar, V 1, Paris, 12-14 April 1989, P 21-33 (13)

Producers Say They're Moving Quickly to Create Safe Substitutes for CFCs, by L Dotto

Challenges, Spring 1989, P 14-15

Recent Warming of Tropical Sea Surface Temperature and its Relationship to the Northern Hemisphere Circulation, by T Nitta, S Yamada Journal of the Meteorological Society of Japan, V 67, N 3, 1989, P 375-383 (9)

Reconstructed Northern Hemisphere Annual Temperature Since 1671 Based on High-Latitude Tree-Ring Data From North America, by G C Jacoby Jr, R D'Arrigo

Climatic Change, V 14, 1989, P 39-59 (21)

Redistribution of the Canadian Boreal Forest Under a Warmed Climate, by $\mathrm{N} E$ Sargent

Climatological Bulletin, V 22(3), 1988, P 23-34 (12)

Reducing Earth's Greenhouse $\mathrm{CO}_{2}$ Through Shifting Staples Production to Woody Plants, by P A Rutter Coping With Climate Change, Proceedings, Second North American Conference on Preparing For Climate Change: A Cooperative Approach, The Climate Institute, Washington, DC, June 1989, P 208-213 (6)

Reducing Greenhouse Gas Emissions - A Case Study of the Electricity, Building and Commercial/Industrial Sectors in the UK, by S T Boyle, I Brown Energy Technologies for Reducing Emissions of Greenhouse Gases, Proceedings of an Expert's Seminar, V 2, Paris, 12-14 April 1989, P 115-134 (20)

Regional and National Effects of Climate Change on Demands for Electricity, by K P Linder Coping With Climate Change, Proceedings, Second North American Conference On Preparing For Climate Change: A Cooperative Approach, The Climate Institute, Washington, DC, June 1989, P 401-405 (5)

Regional Greenhouse Climate Effects, by J Hansen, D Rind, A Delginio, A Lacis, S Lebedeff, M Prather,

R Ruedy, T Karl

Coping With Climate Change, Proceedings, Second North American Conference On Preparing For Climate Change: A Cooperative Approach, The Climate Institute, Washington, DC, June 1989, P 68-81 (16)

Relation Between Increasing Methane and the Presence of Ice Clouds at the Mesopause, by G E Thomas, J J Olivero, E J Jensen, W Schroeder, O B Toon Nature, V 338, 6 April 1989, P 490-491 (2)

Relative Contributions of Greenhouse Gas Emissions to Global Warming, by D A Lashof, D R Ahuja Nature, V 344, 5 April 1990, P 529-531 (3)

Relief for Greenhouse? Don't Cut Old Forests, by R Monastersky Science, V 137, 10 Feb, 1990, P 85 (1)
Report of the Panel on Agriculture, Forestry, and Urban Land Use, by W Easterling

Report of the First US - Canada Symposium on Impacts of Climate Change on the Great Lakes Basin, National Climate Program Office, Canadian Climate Centre, US Environmental Protection Agency, Midwestern Climate Center, Oak Brook, Illinois, 27-29 Sept 1988, P 182-184 (3)

Report on Reducing Greenhouse Gas Emissions Federal/Provincial/Territorial Task Force on Energy and the Environment, Aug 1989, P 1-78, 95-102 (86)

Required Speeds of Fossil Fuel Phase-Out Under a 2 Degree C Global Warming Limit, by F Krause Energy Technologies for Reducing Emissions of Greenhouse Gases, Proceedings of an Expert's Seminar, V 2, Paris, 12-14 April 1989, P 101-114 (14)

Responding to the Challenge of Global Warming: The Role of Energy Efficient Technologies, by G R Davis Energy Technologies for Reducing Emissions of Greenhouse Gases, Proceedings of an Expert's Seminar, V 1, Paris, 12-14 April 1989, P $71-85$ (15)

Response to Climate Change: A Challenge to the Energy and Transportation Sectors, by S J Cohen Report of the First US - Canada Symposium on Impacts of Climate Change on the Great Lakes Basin, National Climate Program Office, Canadian Climate Centre, US Environmental Protection Agency, Midwestern Climate Center, Oak Brook, Illinois, 27-29 Sept 1988, P 102-108 (7)

Response to Kellogg's Paper, by H W Ellsaesser Global Climate Change, Human and Natural Influences, Chapter 3, 1989, P 67-80 (14)

Satellite Data Under Scrutiny, by P D Jones, T M L Wigley

Nature, V 344, 19 April 1990, P 711 (1)

Scenario for Reducing $\mathrm{CO}_{2}$ Emissions from Electricity Generation in England and Wales by Fuel Switching and Energy Conservation, by A J Crane, P L Surman

Energy Technologies for Reducing Emissions of Greenhouse Gases, Proceedings of an Expert's Seminar, V 1, Paris, 12-14 April 1989, P 397-403 (7)

Scenarios for Future Climate Change: Results of GCM Simulations, by M C MacCracken

Report of the First US - Canada Symposium on Impacts of Climate Change on the Great Lakes Basin, National Climate Program Office, Canadian Climate Centre, US Environmental Protection Agency, Midwestern Climate Center, Oak Brook, Illinois, 27-29 Sept 1988, P 43-48 (6)

Scientific Basis for the Greenhouse Effect, by G MacDonald

The Challenge of Global Warming, Chapter 9, 1989, P 123-145 (23)

Scientific Perspectives on the Greenhouse Problem, Executive Summary, by F Seitz, K Bendetsen, R Jastrow, W A Nierenberg

Scientific Perspectives on the Greenhouse Problem, 1989 (16)

Sea Level Rise, Consequences and Policies, by $\mathrm{P}$ Vellinga, S P Leatherman

Climatic Change, V 15, 1989, P 175-189 (15) 
Sea Level Rise: Regional Consequences and Responses, by G P Hekstra

Greenhouse Warming: Abatement and Adaptation, Proceedings of a Workshop, National Oceanic and Atmospheric Administration, US Department of Energy, US Department of Agriculture, US Environmental Protection Agency, International Federal Institute for Advanced Study, Resources for the Future, Washington, DC, 14-15 June 1988, P 53-67 (15)

Sea-Level Rise of Coastal Subsidence? by R W Stewart Atmosphere-Ocean, N 27(3), 1989, P 461-477 (17)

Seasonal Climate Changes Induced by Doubled $\mathrm{CO}_{2}$ as Simulated by the OSU Atmospheric GCM/Mixed Layer Ocean Model, by M E Schlesinger, Z C Zhao Journal of Climate, V 2, N 5, 1989, P 459-495 (37)

Secular Increase of the Total Vertical Column

Abundance of Carbon Monoxide Above Central Europe Since 1950 , by R Zander, P Demoulin, D H Ehhalt,

U Schmidt, C P Rinsland Journal of Geophysical Research, V 94, N D8, 20 Aug 1989, P 11021-11028 (8)

Sensitivity of Climate and Atmospheric $\mathrm{CO}_{2}$ to Deep-Ocean and Shallow-Ocean Carbonate Burial, by T Volk

Nature, V 337, N 6208, 16 Feb 1989, P 637-640 (4)

Sensitivity of Crop Yields and Land Resource Potential to Climate Change in Ontario, Canada, by B Smit,

M Brklacich, R B Stewart, R McBride, M Brown,

D Land

Climatic Change, N 14, 1989, P 153-174 (22)

Sensitivity of Evapotranspiration in a Wheat Field, a Forest, and a Grassland to Changes in Climate and Direct Effects of Carbon Dioxide, by P Martin,

N J Rosenberg, M S McKenney Climatic Change, V 14, 1989, P 117-151 (35)

Short-Term Climatic Change: Evidence, Causes, Environmental Consequences and Strategies For Action, by R D Thompson

Progress in Physical Geography, V 13, N 3, 1989 , P 315-347 (32)

Slowing Global Warming, by C Flavin Environmental Science Technology, V 24, N 2, 1990 , P 170-171 (2)

Socio-Economic Assessment of the Physical and Ecological Impacts of Climate Change on the Marine Environment of the Atlantic Region of Canada -Phase 1 , by $\mathrm{P}$ Stokoe Climate Change Digest, CCD 88-07, 1988 (11)

Some Plants Like it Hot in the Global Greenhouse, by D Charles New Scientist, 2 June 1990, P 31 (1)

Some Remarks on Global Warming, by R S Lindzen Environment Science Technology, V 24, N 4, 1990, P 424-426 (3)

Sources, Sinks, Trends and Opportunities, by

P Ciborowski The Challenge of Global Warming, Chapter 14, 1989, P 213-230 (18)
Spatial Variation of Ozone Depletion Rates in the Springtime Antarctic polar Vortex, by Y L Yung,

M Allen, D Crisp, R W Zurek, S P Sender Science, V 248, 11 May 1990, P 721-724 (4)

Spectroscopic Measurements of Atmospheric Carbon Monoxide and Methane. 1: Latitude Distribution, by

V I Dianov-Klokov, L N Yurganov, E I Grechko,

A V Dzhola

Journal of Atmospheric Chemistry, V 8, 1989, P 139-151 (13)

Stabilisation of the $\mathrm{CO}_{2}$ Greenhouse Effect and

Related Technical Perspectives for the Safe Use of

Nuclear Energy, by F Tondeur

Energy Technologies For Reducing Emissions of Greenhouse Gases, Proceedings of an Expert's Seminar, V 2, Paris, 12-14 April 1989, P 287-300 (14)

Steps Towards an International Convention to Stabilize the Composition of the Atmosphere, by

K Ramakrishna, G M Woodwell Environmental Conservation, V 16, N 2, 1989 , P 163-165 (3)

Strategies to Cope With Climate Change, by

W H Mansfield III

The Changing Atmosphere: Implications for Global Security Proceedings, Secretariat of the World Meteorological Organization, Toronto, 27- 30 June 1988, P 271-277 (7)

Strategies to Respond to Climate Change and Sea

Level Rise in Atlantic Canada, by P K Stokoe Coping With Climate Change, Proceedings, Second North American Conference on Preparing For Climate Change: A Cooperative Approach, The Climate Institute, Washington, DC, June 1989, P 521-525 (5)

Stratospheric Ozone Depletion and Future Levels of Atmospheric Chlorine and Bromine, by M J Prather, R T Watson Nature, V 344, 19 April 1990, P $729-734$ (6)

Streetwise to the Dangers of Ozone, by C Vaughan New Scientist, 26 May 1990, P 56-59 (4)

Substitute Fuels for Road Transport: A Technology Assessment International Energy Agency, 1990 (114)

Summary: Effects on Corn and Soybean Production, by J T Ritchie

Report of the First US - Canada Symposium on Impacts of Climate Change on the Great Lakes Basin, National Climate Program Office, Canadian Climate Centre, US Environmental Protection Agency, Midwestern Climate Center, Oak Brook, Illinois, 27-29 Sept 1988, P 196 (1)

Sustainable Developments and the Biosphere:

Concepts and Principles, by W E Rees Globe '90 International Conference, Vancouver, March 1990 (21) 
Swiss Energy Scenarios: Technologies and Strategies and Their Impact on $\mathrm{CO}_{2}$ Emissions, by $\mathrm{H}$ L Schmid

Energy Technologies For Reducing Emissions of

Greenhouse Gases, Proceedings of an Expert's

Seminar, V 2, Paris, 12-14 April 1989,

P 487-504 (18)

Technical Measures Against Emissions of Greenhouse Gases, by W R A Goossens

Energy Technologies for Reducing Emissions of

Greenhouse Gases, Proceedings of an Expert's

Seminar, V 2, Paris, 12-14 April 1989,

P 553-563 (11)

Technological Options and Policy Strategies to Reduce the Risk of Rapid Global Warming, I V Mintzer

Energy Technologies for Reducing Emissions of

Greenhouse Gases, Proceedings of an Expert's

Seminar, V 1, Paris, 12-14 April 1989,

P 421-440 (20)

Technology and Energy Consumption Trends: Can We Reduce the Uncertainties? by P Criqui

Energy Technologies For Reducing Emissions of

Greenhouse Gases, Proceedings of an Expert's

Seminar, V 2, Paris, 12-14 April 1989,

P 367-379 (13)

Technology Choices for Solving the Greenhouse

Problem, by S Okumura

Energy Technologies for Reducing Emissions of

Greenhouse Gases, Proceedings of an Expert's

Seminar, V 2, Paris, 12-14 April 1989, P 567-573

Temperature Trends at the South Pole and McMurdo

Sound, by K E Trenberth, J G Olson

Journal of Climate, V 2, Oct 1989, P 1196-1206 (11)

Testing the Global Warming Hypothesis, by

A A Tsonis, J B Elsner

Geophysical Research Letters, V 16, N 8, Aug 1989, P 795-797 (3)

The Greenhouse Effect and Climate Change, by

J F B Mitchell

Geophysical Review, V 27, 1 Feb 1989,

P 115-139 (25)

The Arctic Sea Ice Record From Satellite--Is There

Evidence of a Polar Warming? by C L Parkinson Coping With Climate Change, Proceedings, Second North American Conference on Preparing For Climate Change: A Cooperative Approach, The Climate Institute, Washington, DC, June 1989, P 459-463 (5)

The Assessment of Effects of Climatic Variations on Agriculture: Aims, Methods and Summary of Results, by M Parry, T Carter

The Impact of Climatic Variations on Agriculture, V 1: Assessments in Cool Temperate and Cold Regions, Section 1, 1990, P 11-95 (85)

The Beginnings of a Problem, by I A Isaksen Ozone Depletion: Health and Environmental Consequences, Chapter 3, 1989, P 15-25 (11)

The Biggest Greenhouse Still Intact, by J Maddox Nature, V 338, N 6211, 9 March 1989, P 111 (1)
The Biological Consequences of Climate Changes: An Ecological and Economic Assessment, by S S Batie,

H H Shugart

Greenhouse Warming: Abatement and Adaptation, Proceeding of a Workshop, National Oceanic and Atmospheric Administration, US Department of Energy, US Department of Agriculture, US Environmental Protection Agency, International Federal Institute for Advanced Study, Resources for the Future, Washington, DC, 14-15 June 1988, P 121-131 (11)

The Carbon Dioxide Puzzle, by $\mathrm{T}$ Takahashi Oceanus, V 32, N 2, 1989, P 22-29 (8)

The Case For Methanol, by C L Gray Jr, J A Alson Scientific American, V 261, N 5, Nov 1989, P 108-114 (7)

The Causes and Effects of Sea Level Rise, by J G Titus The Challenge of Global Warming, Chapter 12, 1989, P 161-195 (25)

The Challenge of Global Change, by M B McElroy The Changing Atmosphere: Implications for Global Security Proceedings, Secretariat of the World Meteorological Organization, Toronto, 27-30 June 1988, P 106-116 (11)

The Changing Atmosphere, by J Jaeger The Changing Atmosphere: Implications for Global Security Proceedings, Secretariat of the World Meteorological Organization, Toronto, 27- 30 June 1988, P 384-404 (21)

The Changing Atmosphere, by T E Graedel,

P J Crutzen

Scientific American, Sept 1989

P 58, 60-64, 66, 68 (8)

The Changing Atmosphere: Implications for Global Security, by H L Ferguson

The Challenge of Global Warming, Chapter 3, 1989, P 44-62 (19)

The Changing Climate, by S H Schneider Scientific American, Sept 1989, P 70, 72-79 (9)

The Choice of First-Order Impact Models, by T Carter, N Konijn, R Watts

The Impact of Climatic Variations on Agriculture, V 1: Assessments in Cool Temperate and Cold Regions, Section 1, 1990, P 97-123 (27)

The Dangers From Climate Warming: A Public Awakening, by R Pomerance

The Challenge of Global Warming, Chapter 18, 1989, P 259-269 (11)

The Dynamic Greenhouse: Feedback Processes That Can Influence Global Warming, by D A Lashof Coping With Climate Change, Proceedings, Second North American Conference On Preparing For Climate Change: A Cooperative Approach, The Climate Institute, Washington, DC, June 1989, P 102-110 (9)

The Dynamic Greenhouse: Feedback Processes That May Influence Future Concentrations of Atmospheric Trace Gases and Climatic Change, by D A Lashof Climatic Change, V 14, 1989, P 213-242 (30) 
The Ecological Significance of Increasing Atmospheric

Carbon Dioxide, by U Skiba, M Cresser

Endeavour, V 12, N 3, 1988, P 143-147 (5)

The Effect of $\mathrm{CO}_{2}$ Emissions From Coal Fired Power

Plants: A Review in Perspective, by $\mathrm{K}$ M Sullivan

International Coal Development Institute,

May 1988 (20)

The Effects of Climate and Climate Change on the

Economy of Alberta, by T O Goos

Climate Change Digest, 1989 (13)

The Effects of Climatic Variations on Agriculture in Japan, Introduction: The Policy and Planning Issues, by M Yoshino

The Impact of Climatic Variations on Agriculture, V 1: Assessments in Cool Temperate and Cold Regions, Part 6, Section 1, 1990, P 731-750 (20)

The Effects of Climatic Variations on Agriculture in the Subarctic Zone of the USSR. by S E Pitovranov,

V I Kiseler, V N Iakimets, O D Sirotenko

The Impact of Climatic Variations on Agriculture,

V 1: Assessments in Cool Temperate and Cold

Regions, Part 5, 1990, P 617-722 (106)

The Effects of Enriched Carbon Dioxide Atmospheres on Plant--Insect Herbivore Interactions, by E D Fajer, M D Bowers, F A Bazzaz

Science, V 243, 3 March 1989, P 1198-1200 (3)

The Effects on Electric Utilities, by M R Inglis

Report of the First US - Canada Symposium on Impacts of Climate Change on the Great Lakes Basin, National Climate Program Office, Canadian Climate Center, US Environmental Protection Agency, Midwestern Climate Center, Oak Brook, Illinois, 27-29 Sept 1988, P 126-133 (8)

The Effects on Latitudinal Shift of Plant Growth Potential, by Z Uchijima, H Seino

The Impact of Climatic Variations on Agriculture, V 1: Assessments in Cool Temperate and Cold Regions, Part 6, Section 3, 1990, P 773-795 (23)

The Future of the Forest, by A E Lugo

Environment, V 30, N 7, Sept 1988, P 17-20, 41, 43-45 (8)

The Global Effects of Tropical Deforestation, by

R A Houghton

Environment Science Technology, V 24, N 4, 1990,

P 414-415, 418, 420-422 (6)

The Global Greenhouse Effect, by F K Hare

The Changing Atmosphere: Implications for Global Security Proceedings, Secretariat of the World Meteorological Organization, Toronto,

27-30 June 1988, P 59-68 (10)

The Global Warming Debate: Science or Politics? by

S H Schneider

Environment Science Technology, V 24, N 4, 1990, P 432-435 (4)

The Global Warming Problem, Strategies for the Fossil Fuels Industries Under the Threat of Global Climate

Warming, by E J Wiggins, H E Gunning

AOSTRA Oil Sands 2000, Edmonton,

26-28 March 1990, P 1-5 (5)
The Great Climate Debate, by $\mathrm{R} M$ White

Scientific American, V 263, N 1, July 1990, P 36-43 (8)

The Greenhouse Effect and its Connection with the Area of Fossil Fuels: The Concept of $\mathrm{CO}_{2}$ Emission Intensity, by J C Balanceanu, A Bertrand, J J Lacour Energy Technologies For Reducing Emissions of Greenhouse Gases, Proceedings of an Expert's Seminar, V 1, Paris, 12-14 April 1989, P 193-205 (14)

The Greenhouse Effect and the Alberta Fossil Fuels Industry, by E J Wiggins, W J Yurko Alberta Oil Sands Technology and Research Authority, July 1989 (47)

The Greenhouse Effect as a Symptom of Our Collective Angst, by J Namias

Oceanus, 1989 (3)

The Greenhouse Effect, by K P Shine

Ozone Depletion: Health and Environmental

Consequences, Chapter 7, 1989, P 71-83 (13)

The Greenhouse Effect, Sea-Level Rise and Coastal Geomorphology, by H A Viles

Progress in Physical Geography, V 13, N 3, 1989, P 452-461 (5)

The Greenhouse Effect: Impacts on Current Global Temperature and Regional Heat Waves, by

J E Hansen

The Challenge of Global Warming, Chapter 2, 1989, P 35-43 (9)

The Greenhouse Effect: Its Causes, Possible Impacts, and Associated Uncertainties, by S H Schneider, N J Rosenberg

Greenhouse Warming: Abatement and Adaptation, Proceeding of a Workshop, National Oceanic and Atmospheric Administration, US Department of Energy, US Department of Agriculture, US Environmental Protection Agency, International Federal Institute for Advanced Study, Resources for the Future, Washington, DC, 14-15 June 1988, P 7-34 (28)

The Greenhouse Effect: Reality or Media Event, by S H Schneider

Coping With Climate Change, Proceedings, Second North American Conference On Preparing For Climate Change: A Cooperative Approach, The Climate Institute, Washington, DC, June 1989, P 57-67 (11)

The Greenhouse Effect: Science and Policy, by S H Schneider

Science, V 243, 10 Feb 1989, P 771-781 (11)

The Greenhouse Theory of Climate Change: A Test by an Inadvertent Global Experiment, by V Ramanathan Science, V 240, 15 April 1988, P 293-299 (7)

The Heat Trap, by J H W Karas, P M Kelly Friends of the Earth, Nov 1989 (129)

The Hole in the Sky: Man's Threat to the Ozone Layer, by $\mathrm{J}$ Gribbin

Bantam Books, 1988 (192) 
The Impact of Climate Change on Continuous Corn Production in the Southern USA, by E J Cootes Climatic Change, V 16, 1990, P 53-82 (30)

The Impact of Climate Change on Water Quality in the Southern USA: Stream Water Temperature, by E Cooter, W Cooter

Coping With Climate Change, Proceedings, Second North American Conference on Preparing For Climate Change: A Cooperative Approach, The Climate Institute, Washington, DC, June 1989, P 501-505 (5)

The Impact on Water Supplies, by H E Schwarz, L A Dillard

Oceanus, V 32, N 2, 1989, P 44-45 (2)

The Impacts of Climate Change on the Salinity of San Francisco Bay, by P B Williams

Coping With Climate Change, Proceedings, Second North American Conference on Preparing For Climate Change: A Cooperative Approach, The Climate Institute, Washington, DC, June 1989, P 474-478 (5)

The Implications of Climate Change for Agriculture in the Prairie Provinces, by L M Arthur Climate Change Digest, CCD 88-01, 1988 (15)

The Implications of Climate Change for Natural Resources in Quebec, by B Singh Climate Change Digest, CCD 88-08, 1988 (14)

The Implications of Global Climatic Changes for International Security, by P H Gleick Climatic Change, V 15, 1989, P 309-325 (17)

The Influence of Termites on Atmospheric Trace Gases: $\mathrm{CH} 4, \mathrm{CO}_{2}, \mathrm{CHCl} 3, \mathrm{~N} 2 \mathrm{O}, \mathrm{CO}, \mathrm{H} 2$ and Light Hydrocarbons, by M A K Khalil, R A Rasmussen, J R J French, J A Holt Journal of Geophysical Research, V 95, N D4, 20 March 1990, P 3619-3634 (16)

The Interaction of Air Pollution Programs and Global Climate Change, by J Emison Coping With Climate Change, Proceedings, Second North American Conference On Preparing For Climate Change: A Cooperative Approach, The Climate Institute, Washington, DC, June 1989, P 231- 233 (3)

The Message From the Oceans, by J H Steele Oceanus, V 32, N 2, 1989, P 4-9 (6)

The Montreal Ozone Protocol: Lessons for Global Warming, by R E Benedick Coping With Climate Change, Proceedings, Second North American Conference On Preparing For Climate Change: A Cooperative Approach, The Climate Institute, Washington, DC, June 1989, P 35-39 (5)

The Montreal Protocol on Substances that Deplete the Ozone Layer: Its Development and Likely Impact, by

P Usher

Ozone Depletion: Health and Environmental Consequences, Chapter 11, 1989, P 115-140 (26)

The Montreal Protocol: A Dynamic Agreement for Protecting the Ozone Layer, by J Koehler, S A Hajost Ambio, V 19, N 2, April 1990, P 82-86 (5)
The Near Term Contribution of Nuclear Energy in Reducing $\mathrm{CO}_{2}$ Emissions in OECD Countries, by K Todani, Y M Park, G H Stevens

Energy Technologies For Reducing Emissions of Greenhouse Gases, Proceedings of an Expert's

Seminar, V 1, Paris, 12-14 April 1989, P 59-69 (11)

The Near- and Far-Term Technologies, Uses, and

Future of Natural Gas, by G J MacDonald Energy Technologies for Reducing Emissions of Greenhouse Gases, Proceedings of an Expert's Seminar, V 1, Paris, 12-14 April 1989, P 509-535 (27)

The Potential Enhanced Greenhouse Effect:

Status/Projections/Concerns and Needs for

Constructive Approaches, by D G Levine Energy Technologies for Reducing Emissions of Greenhouse Gases, Proceedings of an Expert's Seminar, V 1, Paris, 12-14 April 1989, P 131-159 (29)

The Potential for Geothermal Energy, by J W Tester, D W Brown, R M Potter

Coping With Climate Change, Proceedings, Second North American Conference On Preparing For Climate Change: A Cooperative Approach, The Climate Institute, Washington, DC, June 1989, P 613-626 (14)

The Potential for Reduced $\mathrm{CO}_{2}$ Emissions Through Increased Energy Efficiency and the Use of Renewable Energy Technologies in Australia, by I J Walker, K D Lyall

Energy Technologies For Reducing Emissions of Greenhouse Gases, Proceedings of an Expert's Seminar, V 2, Paris, 12-14 April 1989, P 435-453 (19)

The Potential Longer Term Contribution of Nuclear Energy in Reducing $\mathrm{CO}_{2}$ Emissions in OECD

Countries, by W Gehrisch, T Haapalainen, Y M Park,

G H Stevens, K Todani

Energy Technologies for Reducing Emissions of Greenhouse Gases, Proceedings of an Expert's Seminar, V 1, Paris, 12-14 April 1989,

P 619-633 (15)

The Radiative and Climate Consequences of the Changing Atmospheric Composition of Trace Gases, by V Ramanathan

The Changing Atmosphere, 1988, P 159-186 (28)

The Reality of the Greenhouse Effect, by

M C MacCracken

Coping With Climate Change, Proceedings, World

Petroleum Congress, V 12, N 5, 1988, P 133-140 (8)

The Relationship Between Relative Sea-Level Rise and Coastal Upland Retreat in New England, by G S Giese, D G Aubrey

Coping With Climate Change, Proceedings, Second

North American Conference On Preparing For Climate Change: A Cooperative Approach, The Climate Institute, Washington, DC, June 1989, P 516-520 (5) 
The Relationship of Global Climate Change to Other Air Quality Issues, by J C Bernabo

Coping With Climate Change, Proceedings, Second North American Conference On Preparing For Climate Change: A Cooperative Approach, The Climate Institute, Washington, DC, June 1989, P 224- 228 (5)

The Road to Fuel Efficiency in the Passenger Vehicle Fleet, by S E Plotkin

Environment, V 31, N 6, July-Aug 1989,

P 18-19, 36-42 (9)

The Role of Carbon Dioxide Removal in the Reduction of the Greenhouse Effect, by K Blok, C A Hendriks,

W C Turkenberg

Energy Technologies for Reducing Emissions of Greenhouse Gases, Proceeding of an Expert's Seminar, V 2, Paris, 12-14 April 1989, P 135-155 (21)

The Role of Cloud Microphysical Processes in Climate: An Assessment From a One-Dimensional Perspective, by $\mathrm{K}$ N Lios, S C Ou Journal of Geophysical Research, V 94, N D6, 20 June 1989, P 8599-8607 (9)

The Role of Cloud Microphysics in High-Cloud Feedback Effects on Climate Change, by C M R Platt Nature, V 341, 5 Oct 1989, P 428-429 (2)

The Role of Coal Use and Technology in the Greenhouse Effect, by I M Smith Energy Technologies for Reducing Emissions of Greenhouse Gases, Proceedings of an Expert's Seminar, V 1, Paris, 12-14 April 1989, P 283-294 (12)

The Role of the Seas in the Planetary Hothouse, by F Golden Oceanus, 1989 (2)

The Scientific Consensus The Challenge of Global Warming, Chapter 4, 1989, P 63-67 (5)

The Selection of Energy, Technologies Under Conditions of Restricted Carbon Emissions: The Danger of Premature Judgements, by J H Walsh Energy Technologies for Reducing Emissions of Greenhouse Gases, Proceedings of an Expert's Seminar, V 2, Paris, 12-14 April 1989, P 3-13 (11)

The Sensitivity of Some High-Latitude Boreal Forests to Climatic Parameters, by G B Bonan, H H Shugart, D L Urban

Climatic Change, V 16, 1990, P 9-29 (21)

The Significance of the Date of Snow Disappearance on the Arctic Tundra as a Possible Indicator of Climate Change, by J L Foster

Arctic and Alpine Research, V 21, N 1, 1989, P 60-70 (11)

The Thermal Response of the Tropical Atmosphere to Variations in Equatorial Pacific Sea Surface

Temperature, by G C Reid, K S Gage, J R McAfee Journal of Geophysical Research, V 94, N D12, Oct 1989 , P 14705-14716 (12)
The Threat to Federal Coastal Protection Goals from Global Warming and Accelerated Sea Level Rise, by

L T Edgerton

Coping With Climate Change, Proceedings, Second North American Conference on Preparing For Climate Change: A Cooperative Approach, The Climate Institute, Washington, DC, June 1989, P 359-365 (7)

The Two Faces of Ozone, by R Monastersky Science News, V 136, 2 Sept 1989, P 154-155

The Vertical Distribution of CH4, N2O, CFC-12 and CFC-11 in the Middle Atmosphere at Mid-Latitudes, by

S Lal, R Borchers, P Fabian and B C Krueger Journal of Atmospheric and Terrestrial Physics, V 51, N 2, 1989, P 81-90 (10)

The Warming of the Industrialized Middle Latitudes 1985-2050: Causes and Consequences, by

G M Woodwell Climatic Change, V 15, 1989, P 31-50 (20)

The 1988 US Drought Linked to Anomalous Sea Surface Temperature, by T N Palmer, C Brankovic Nature V 338, 2 March 1989, P 54-57 (4)

Thoughts on Abatement and Adaption, by R R Revelle Greenhouse Warming: Abatement and Adaptation, Proceedings of a Workshop, National Oceanic and Atmospheric Administration, US Department of Energy, US Department of Agriculture, US Environmental Protection Agency, International Federal Institute for Advanced Study, Resources for the Future, Washington, DC, 14-15 June 1988, P 167-174 (8)

Tough Air-Quality Goals Spur Quest for

Transportation Fuel Changes, by R A Corbett Oil \& Gas Journal, 18 June 1990, P 33-34, 36, 39-42 (7)

Toward an International Convention for the Protection of the Global Climate: Financial Framework, by W Bach, H Scheer

Coping With Climate Change, Proceedings, Second North American Conference On Preparing For Climate Change: A Cooperative Approach, The Climate Institute, Washington, DC, June 1989, P 673-681 (9)

Towards a Greenhouse Convention Nature, V 339, 1 June 1989, P 323-324 (2)

Towards a New Era of Electricity in Harmony with the Global Environment -- A Report From Japanese Electric Utility Industry, by J Yamaguchi Energy Technologies For Reducing Emissions of Greenhouse Gases, Proceedings of an Expert's Seminar, V 2, Paris, 12-14 April 1989, P 505-513 (9)

Towards a Strategy for Adapting to Climate Change in Alberta, by R K W Wong, M English, F D Barlow, L Cheng, K R Tremaine Alberta Research Council, 1989 (85)

Trace Gases, $\mathrm{CO}_{2}$, Climate, and the Greenhouse Effect, by G J Aubrecht II

The Physics Teacher, March 1988, P 145-152 (8) 
Transient Climate Response to an Increase of

Greenhouse Gases, by L D D Harvey

Climatic Change, V 15, 1989, P 15-30 (16)

Transportation Energy Strategies and the Greenhouse Effect, by D Sperling, M A DeLuchi

Energy Technologies for Reducing Emissions of Greenhouse Gases, Proceedings of an Expert's Seminar, V 2, Paris, 12-14 April 1989, P 53-68 (16)

Tropical Deforestation and Climate Change, by N Myers Environmental Conservation, V 15, N 4, 1988, P 293-298 (6)

Tropical Deforestation: Some Effects on Atmospheric Chemistry, by T J Goreau, W Z de Mello Ambio, V 17, N 4, 1988, P 275-281 (7)

Tropical Forests and Climate, by $\mathrm{N}$ Myers Coping With Climate Change, Proceedings, Second North American Conference on Preparing For Climate Change: A Cooperative Approach, The Climate Institute, Washington, DC, June 1989, P 310-312 (3)

Tropical Forests and Green House Gases, by

P S Ashton

Energy Technologies for Reducing Emissions of Greenhouse Gases, Proceedings of an Expert's Seminar, V 1, Paris, 12-14 April 1989, P 247-254

Tropospheric Lifetimes of Halogenated Anaesthetics, by A C Brown, C E Canosa-Mas, A D Parr,

J M T Pierce, R P Wayne Nature, V 341, N 6243, 19 Oct 1989, P 635-637 (3)

Turning Down the Heat, by J R Udall Sierra, Jul-Aug 1989, P 26-33 (8)

Two Low $\mathrm{CO}_{2}$ ' Energy Scenarios for the Netherlands, by T Kram, P A Okken Energy Technologies For Reducing Emissions of

Greenhouse Gases, Proceedings of an Expert's Seminar, V 2, Paris, 12-14 April 1989, P 465-486 (22)

Two Gales Do Not Make a Greenhouse, by J Maddox Nature, V 343, 1 Feb 1990, P 407 (1)

US - Soviet Collaboration in Energy Conservation: Research and Development Initiatives to Cope with

Climate Concerns, by R H Socolow

Energy Technologies for Reducing Emissions of Greenhouse Gases, Proceedings of an Expert's Seminar, V 2, Paris, 12-14 April 1989, P 575-581

Uncertainties in Energy Models, by J Edmonds Coping With Climate Change, Proceedings, Second North American Conference On Preparing For Climate Change: A Cooperative Approach, The Climate Institute, Washington, DC, June 1989, P 557-560 (4)

Uncertainties of Estimates of Climatic Change: A

Review, by $\mathrm{R}$ E Dickinson Climatic Change, V 15, 1989, P 5-13 (9)

Urban Bias in Area-Averaged Surface Air Temperature Trends, by T R Karl, P D Jones Bulletin American Meteorological Society, V 70, N 3, March 1989, P 265-270 (6)
Urban Bias in Area-Averaged Surface Air

Temperature Trends, by T R Karl, P D Jones Bulletin American Meteorological Society, V 70 , N 3, March 1989, P 265-270 (6)

US Congress Plans Greenhouse Legislation, by

D Swinbanks Nature, V 338, N 6210, 2 March 1989, P 3 (1)

Using Climate Change Scenarios to Model

Agroclimatic and Ecoclimatic Consequences, by

E E Wheaton Forest Modelling Symposium, Saskatoon, 14-15 March 1989 (22)

Volcanoes Can Muddle the Greenhouse, by R A Kerr Science, V 245, 14 July 1989, P 127-128 (2)

Vulnerability of United States Water Systems to Climate Change, by $\mathrm{P}$ H Gleick

Coping With Climate Change, Proceedings, Second North American Conference On Preparing For Climate Change: A Cooperative Approach, The Climate Institute, Washington, DC, June 1989, P 327- 336 (10)

Warmer Clouds Could Keep Earth Cooler, by

$\mathrm{R}$ Monastersky

Science News, V 136, 1989, P 196 (1)

Warmer Seas Increase Greenhouse Effect, by J Gribbin New Scientist, 6 Jan 1990, P 31 (1)

Water Resources and Climate Change, by

K D Frederick, P H Gleick

Greenhouse Warming: Abatement and Adaptation, Proceedings of a Workshop, National Oceanic and Atmospheric Administration, US Department of Energy, US Department of Agriculture, US Environmental Protection Agency, International Federal Institute for Advanced Study, Resources for the Future, Washington, DC, 14-15 June 1988, P 133- 143 (11)

West Arctic Ice Won't Melt Quickly, by J Hecht New Scientist, 17 June 1989, P 41 (1)

What Will Be the Fate of Clean-Coal Technologies, by P C Cruver

Environment Science Technology, V 23, N 9, 1989, P 1059-1060 (2)

Where Do We Stand With the $\mathrm{CO}_{2}$ Greenhouse Effect Problem? by H E Landsberg Global Climate Change, Human and Natural Influences, Chapter 5, 1989, P 87-89 (3)

Will There Be a Global Greenhouse Warming?, by

R A Bryson Environmental Conservation, V 16, N 2, 1989, P 97-99 (3)

World Energy Supply and Greenhouse Effect, by A Rose Molecular Crystals and Liquid Crystals, V 175, 1989, P 159-168 (10) 


\section{Literature Review on The Greenhouse Effect Publication Questionnaire}

Is this publication:

${ }_{002} \square$ a reviewed scientific paper

$\square$ an official government report

$\square$ a technical report

$\square$ other type of publication

Does the paper address:

${ }_{005} \square$ computer modelling of world climate

$\square$ monitoring and/or observations of the atmosphere or the climate

the impacts of climate change

technological solutions

$\square$ adaptation strategies

$\square$ review of the issue 


\section{REGARDING COMPUTER MODELLING OF CLIMATE}

What type of emissions does the paper address:

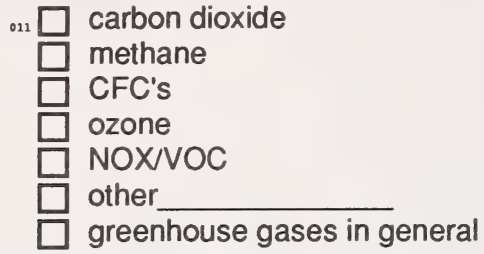

When is the effective doubling of greenhouse gases expected to occur:

${ }^{018} \square$ by 2020
$\square$ by 2050
$\square$ by 2080
$\square$ later
$\square$ never

What will the effect be on average annual temperature if there is an effective doubling of greenhouse gases:

\begin{tabular}{|c|c|c|c|}
\hline Global & $\begin{array}{l}\text { Northern } \\
\text { Latitudes }\end{array}$ & Alberta & \\
\hline & $\square$ & $\square$ & a decrease \\
\hline & $\square$ & $\square$ & no change \\
\hline & $\square$ & $\square$ & an increase of less than $1 \mathrm{C}^{\circ}$ \\
\hline & $\vec{\square}$ & $\square$ & an increase of 1 to $1.9 \mathrm{C}^{\circ}$ \\
\hline & $\square$ & $\square$ & an increase of 2 to $2.9 \mathrm{C}^{\circ}$ \\
\hline & 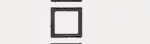 & $\bar{\square}$ & an increase of 3 to $3.9 \mathrm{C}^{\circ}$ \\
\hline & $\neg$ & $\square$ & an increase of 4 to $4.9 \mathrm{C}^{\circ}$ \\
\hline & $\square$ & $\square$ & an increase of 5 to $5.9 \mathrm{C}^{\circ}$ \\
\hline & $\square$ & $\square$ & an increase of $6 \mathrm{C}^{\circ}$ or more \\
\hline & $\square$ & $\square$ & both increases and decreases depending on locatio \\
\hline
\end{tabular}

What will the effect be on total annual precipitation if there is an effective doubling of greenhouse gases:

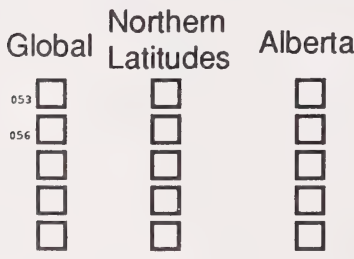

both increases and decreases depending on location no change on average, no change on average, an increase in precipitation on average, a decrease in precipitation

Does the paper address changes in weather extremes?<smiles></smiles> 


\section{REGARDING MONITORING}

Is the composition of the atmosphere changing?

${ }_{070} \square$ Yes $\square$ No $\square$ Possibly

If the composition of the atmosphere is changing, what components are changing:

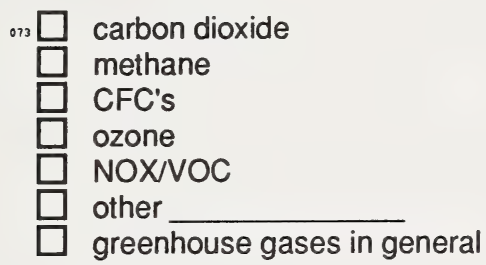

Global Regional

Yes No Maybe Yes No Maybe

${ }_{\circ} \square \square \square \square \square \square$ Over the past century, has there been an increase in average annual temperature

ஃ $\square \square \square \square \quad$ If a temperature increase has been observed in the past century, is it statistically significant

${ }^{\circ} \square \square \square \square \square \square$ Over the past decade, has there been an increase in average annual temperature

$\square \square \quad \square \square \quad$ If a temperature increase has been observed in the past decade, is it statistically significant

${ }_{100} \square \square \square \square \square \square$ Over the past decade, has there been a change in precipitation

$\square \square \square \square \square \square$ Over the past decade, has there been a change in weather extremes

Is the observed change in temperature consistent with what would be expected from

${ }_{122} \square$ a change in atmospheric composition

$\square$ a change in solar activity or earth orbit

$\square$ urban warming

$\square$ other causes 


\section{IMPACTS}

What are the impacts if there is an effective doubling of greenhouse gases in the atmosphere:

$$
\begin{aligned}
& + \text { Positive } \\
& \text { - Negative } \\
& \text { X Both Positive and Negative } \\
& 0 \text { Neutral } \\
& \text { ? Unknown consequences }
\end{aligned}
$$

World Canada Prairies Alberta

$\begin{array}{ll}\square \square & \square\end{array} \begin{aligned} & \text { on agriculture } \\ & \text { on forestry } \\ & \text { on the energy industry } \\ & \text { on tourism } \\ & \text { on the general economy } \\ & \text { on employment } \\ & \square\end{aligned}$

\section{Strategies/Solutions}

Are adaptation strategies suggested for

${ }^{16 .} \square$ agriculture
$\square$ forestry
$\square$ water management
$\square$ tourism
$\square$ coastal policies
$\square$ other

Are limitation strategies suggested for emissions/concentrations of:

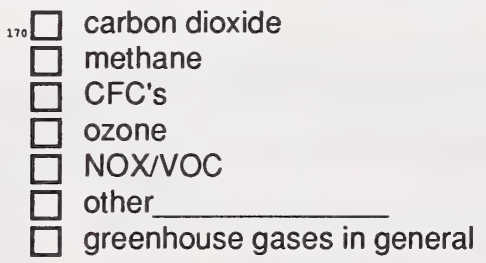

What technological solutions are suggested:
${ }^{21} \square$ energy efficiency/conservation
$\square$ fuel substitution
$\square$ carbon dioxide capture
$\square$ clean combustion
$\square$ aforestation/reforestation
$\square$ landfills and novel feeding procedures
$\square$ climate modification
$\square$ other 


\section{Topics Addressed}

\begin{tabular}{cccccc} 
All & All & All & Non- & Refereed & Refereed \\
Papers & Refereed & Review & Review \\
Papers & Papers & Papers & Papers & Non-Review \\
& Papers \\
\hline
\end{tabular}

$\begin{array}{lcccccc}\text { Modelling } & 122 & 71 & 59 & 63 & 29 & 42 \\ \text { Monitoring } & 136 & 78 & 50 & 86 & 22 & 56 \\ \text { Impacts } & 192 & 77 & 52 & 140 & 28 & 49 \\ \text { Strategies } & 151 & 36 & 33 & 118 & 13 & 23 \\ \text { Solutions } & 156 & 37 & 29 & 127 & 10 & 27 \\ \text { Review } & 119 & 54 & 119 & 0 & 54 & 0\end{array}$

\section{Regarding Computer Modelling Of Climate} Type Of Emissions Addressed

\begin{tabular}{lcccccc} 
& $\begin{array}{c}\text { All } \\
\text { Papers }\end{array}$ & $\begin{array}{c}\text { All } \\
\text { Refereed } \\
\text { Papers }\end{array}$ & $\begin{array}{c}\text { All } \\
\text { Review } \\
\text { Papers }\end{array}$ & $\begin{array}{c}\text { Non- } \\
\text { Review } \\
\text { Papers }\end{array}$ & $\begin{array}{c}\text { Refereed } \\
\text { Review } \\
\text { Papers }\end{array}$ & $\begin{array}{c}\text { Refereed } \\
\text { Non-Review } \\
\text { Papers }\end{array}$ \\
\hline $\begin{array}{l}\text { Carbon } \\
\text { dioxide }\end{array}$ & 69 & 42 & 28 & 41 & 15 & 27 \\
Methane & 6 & 4 & 3 & 3 & 2 & 2 \\
CFCs & 11 & 6 & 4 & 7 & 1 & 5 \\
Ozone & 5 & 2 & 3 & 2 & 1 & 1 \\
NOX/VOC & 4 & 2 & 2 & 2 & 1 & 1 \\
Other & 3 & 3 & 2 & 1 & 2 & 1 \\
Greenhouse & 40 & 23 & 28 & 12 & 16 & 7 \\
gases & & & & & &
\end{tabular}

\section{Regarding Computer Modelling Of Climate When Is The Effective Doubling Of Greenhouse Gases To Occur?}

\begin{tabular}{|c|c|c|c|c|c|}
\hline $\begin{array}{c}\text { All } \\
\text { Papers }\end{array}$ & $\begin{array}{c}\text { All } \\
\text { Refereed } \\
\text { Papers }\end{array}$ & $\begin{array}{c}\text { All } \\
\text { Review } \\
\text { Papers }\end{array}$ & $\begin{array}{l}\text { Non- } \\
\text { Review } \\
\text { Papers }\end{array}$ & $\begin{array}{c}\text { Refereed } \\
\text { Review } \\
\text { Papers }\end{array}$ & $\begin{array}{c}\text { Refereed } \\
\text { Non-Review } \\
\text { Papers }\end{array}$ \\
\hline
\end{tabular}

$\begin{array}{lcccccc}\text { By } 2020 & 18 & 7 & 10 & 8 & 4 & 3 \\ \text { By } 2050 & 41 & 23 & 27 & 14 & 14 & 9 \\ \text { By } 2080 & 12 & 7 & 5 & 7 & 1 & 6 \\ \text { Later } & 3 & 3 & 2 & 1 & 2 & 1 \\ \text { Never } & 0 & 0 & 0 & 0 & 0 & 0\end{array}$

Regarding Computer Modelling Of Climate Effect On Global Temperature Of An Effective Doubling Of Greenhouse Gases

\begin{tabular}{cccccc} 
All & All & All & Non- & Refereed & Refereed \\
Papers & $\begin{array}{c}\text { Refereed } \\
\text { Papers }\end{array}$ & $\begin{array}{c}\text { Review } \\
\text { Papers }\end{array}$ & Papers & $\begin{array}{c}\text { Review } \\
\text { Papers }\end{array}$ & $\begin{array}{c}\text { Non-Review } \\
\text { Papers }\end{array}$ \\
\hline
\end{tabular}

\begin{tabular}{|c|c|c|c|c|c|}
\hline A decrease & 1 & 1 & 0 & 1 & 0 \\
\hline No change & 0 & 0 & 0 & 0 & 0 \\
\hline $\begin{array}{c}\text { Increase } \\
<1^{\circ} \mathrm{C}\end{array}$ & 3 & 2 & 2 & 1 & 1 \\
\hline $\begin{array}{l}\text { Increase } \\
1 \text { to } 1.9^{\circ} \mathrm{C}\end{array}$ & 11 & 6 & 8 & 3 & 3 \\
\hline $\begin{array}{l}\text { Increase } \\
2 \text { to } 2.9^{\circ} \mathrm{C}\end{array}$ & 15 & 10 & 8 & 7 & 4 \\
\hline $\begin{array}{l}\text { Increase } \\
3 \text { to } 3.9^{\circ} \mathrm{C}\end{array}$ & 53 & 28 & 37 & 16 & 19 \\
\hline $\begin{array}{l}\text { Increase } \\
4 \text { to } 4.9^{\circ} \mathrm{C}\end{array}$ & 21 & 12 & 14 & 7 & 7 \\
\hline $\begin{array}{l}\text { Increase } \\
5 \text { to } 5.9^{\circ} \mathrm{C}\end{array}$ & 5 & 2 & 2 & 3 & 0 \\
\hline $\begin{array}{l}\text { Increase } \\
6^{\circ} \mathrm{C} \text { or more }\end{array}$ & 1 & 0 & 0 & 1 & 0 \\
\hline
\end{tabular}

Regarding Computer Modelling Of Climate Effect On Temperature In Northern Latitudes Of An Effective Doubling Of Greenhouse Gases $\begin{array}{cccccc}\text { All } & \text { All } & \text { All } & \text { Non- } & \text { Refereed } & \text { Refereed } \\ \text { Papers } & \begin{array}{c}\text { Refereed } \\ \text { Papers }\end{array} & \text { Review } & \text { Review } & \text { Review } & \text { Non-Review } \\ \text { Papers } & \text { Papers } & \text { Papers }\end{array}$

\begin{tabular}{|c|c|c|c|c|c|}
\hline A decrease & 0 & 0 & 0 & 0 & 0 \\
\hline No change & 0 & 0 & 0 & 0 & 0 \\
\hline $\begin{array}{l}\text { Increase } \\
<1^{\circ} \mathrm{C}\end{array}$ & 0 & 0 & 0 & 0 & 0 \\
\hline $\begin{array}{l}\text { Increase } \\
1 \text { to } 1.9^{\circ} \mathrm{C}\end{array}$ & 0 & 0 & 0 & 0 & 0 \\
\hline $\begin{array}{l}\text { Increase } \\
2 \text { to } 2.9^{\circ} \mathrm{C}\end{array}$ & 1 & 1 & 0 & 1 & 0 \\
\hline $\begin{array}{l}\text { Increase } \\
3 \text { to } 3.9^{\circ} \mathrm{C}\end{array}$ & 3 & 2 & 1 & 2 & 1 \\
\hline $\begin{array}{l}\text { Increase } \\
4 \text { to } 4.9^{\circ} \mathrm{C}\end{array}$ & 4 & 2 & 1 & 3 & 1 \\
\hline $\begin{array}{l}\text { Increase } \\
5 \text { to } 5.9^{\circ} \mathrm{C}\end{array}$ & 6 & 2 & 3 & 3 & 1 \\
\hline $\begin{array}{l}\text { Increase } \\
6^{\circ} \mathrm{C} \text { or more }\end{array}$ & 8 & 3 & 5 & 3 & 1 \\
\hline
\end{tabular}


Regarding Computer Modelling Of Climate Effect On Temperature In Alberta

Of An Effective Doubling Of Greenhouse Gases

All All All Non- Refereed Refereed Papers Refereed Review Review Review Non-Review Papers Papers Papers Papers Papers

\begin{tabular}{|c|c|c|c|c|c|}
\hline A decrease & 0 & 0 & 0 & 0 & 0 \\
\hline No change & 0 & 0 & 0 & 0 & 0 \\
\hline $\begin{array}{l}\text { Increase } \\
<1^{\circ} \mathrm{C}\end{array}$ & 0 & 0 & 0 & 0 & 0 \\
\hline $\begin{array}{l}\text { Increase } \\
1 \text { to } 1.9^{\circ} \mathrm{C}\end{array}$ & 0 & 0 & 0 & 0 & 0 \\
\hline $\begin{array}{l}\text { Increase } \\
2 \text { to } 2.9^{\circ} \mathrm{C}\end{array}$ & 0 & 0 & 0 & 0 & 0 \\
\hline $\begin{array}{l}\text { Increase } \\
3 \text { to } 3.9^{\circ} \mathrm{C}\end{array}$ & 0 & 0 & 0 & 0 & 0 \\
\hline $\begin{array}{l}\text { Increase } \\
4 \text { to } 4.9^{\circ} \mathrm{C}\end{array}$ & 0 & 0 & 0 & 0 & 0 \\
\hline $\begin{array}{l}\text { Increase } \\
5 \text { to } 5.9^{\circ} \mathrm{C}\end{array}$ & 1 & 0 & 0 & 1 & 0 \\
\hline $\begin{array}{l}\text { Increase } \\
6^{\circ} \mathrm{C} \text { or more }\end{array}$ & 0 & 0 & 0 & 0 & 0 \\
\hline
\end{tabular}

Regarding Computer Modelling Of Climate Effect On Global Total Precipitation Of An Effective Doubling Of Greenhouse Gases

\begin{tabular}{|c|c|c|c|c|c|c|}
\hline & $\begin{array}{c}\text { All } \\
\text { Papers }\end{array}$ & $\begin{array}{c}\text { All } \\
\text { Refereed } \\
\text { Papers }\end{array}$ & $\begin{array}{c}\text { All } \\
\text { Review } \\
\text { Papers }\end{array}$ & $\begin{array}{l}\text { Non- } \\
\text { Review } \\
\text { Papers }\end{array}$ & $\begin{array}{c}\text { Refereed } \\
\text { Review } \\
\text { Papers }\end{array}$ & $\begin{array}{l}\text { Refereed } \\
\text { Non-Review } \\
\text { Papers }\end{array}$ \\
\hline $\begin{array}{l}\text { Increases } \\
\& \text { decreases }\end{array}$ & $\mathrm{s}^{17}$ & 13 & 11 & 6 & 8 & 5 \\
\hline No change & 0 & 0 & 0 & 0 & 0 & 0 \\
\hline $\begin{array}{l}\text { On average } \\
\text { no change }\end{array}$ & 1 & 0 & 1 & 0 & 0 & 0 \\
\hline $\begin{array}{l}\text { On average } \\
\text { an increase }\end{array}$ & 10 & 4 & 7 & 3 & 3 & 1 \\
\hline $\begin{array}{c}\text { On average } \\
\text { a decrease }\end{array}$ & 1 & 0 & 1 & 0 & 0 & 0 \\
\hline
\end{tabular}

Regarding Computer Modelling Of Climate Effect On Total Precipitation In Northern Latitudes Of An Effective Doubling Of Greenhouse Gases

\begin{tabular}{cccccc} 
All & All & All & Non- & Refereed & Refereed \\
Papers & Refereed \\
Papers & Review & Review \\
Papers & Papers & Papers & $\begin{array}{c}\text { Ron-Review } \\
\text { Papers }\end{array}$ \\
\hline
\end{tabular}

$\begin{array}{ccccccc}\begin{array}{c}\text { Increases } \\ \text { \& decreases }\end{array} & 3 & 2 & 0 & 3 & 0 & 2 \\ \begin{array}{c}\text { No change } \\ \begin{array}{c}\text { On average } \\ \text { no change }\end{array}\end{array} & 1 & 1 & 0 & 1 & 0 & 0 \\ \begin{array}{c}\text { On average } \\ \text { an increase }\end{array} & 10 & 6 & 7 & 3 & 5 & 1 \\ \begin{array}{c}\text { On average } \\ \text { a decrease }\end{array} & 3 & 2 & 1 & 2 & 0 & 1 \\ \end{array}$

Regarding Computer Modelling Of Climate Effect On Total Precipitation In Alberta Of An Effective Doubling Of Greenhouse Gases

$\begin{array}{ccccccc}\begin{array}{c}\text { Increases \& } \\ \text { decreases }\end{array} & 1 & 0 & 0 & 1 & 0 & 0 \\ \begin{array}{c}\text { No change } \\ \begin{array}{c}\text { On average } \\ \text { no change }\end{array}\end{array} & 0 & 0 & 0 & 0 & 0 & 0 \\ \begin{array}{c}\text { On average } \\ \text { an increase }\end{array} & 2 & 1 & 1 & 1 & \text { I } & 0 \\ \begin{array}{c}\text { On average } \\ \text { a decrease }\end{array} & 0 & 0 & 0 & 0 & 0 & 0\end{array}$

Regarding Computer Modelling Of Climate Are Changes In Weather Extremes Addressed?

\begin{tabular}{|c|c|c|c|c|c|}
\hline $\begin{array}{c}\text { All } \\
\text { Papers }\end{array}$ & $\begin{array}{c}\text { All } \\
\text { Refereed } \\
\text { Papers }\end{array}$ & $\begin{array}{c}\text { All } \\
\text { Review } \\
\text { Papers }\end{array}$ & $\begin{array}{c}\text { Non- } \\
\text { Review } \\
\text { Papers }\end{array}$ & $\begin{array}{c}\text { Refereed } \\
\text { Review } \\
\text { Papers }\end{array}$ & $\begin{array}{c}\text { Refereed } \\
\text { Non-Review } \\
\text { Papers }\end{array}$ \\
\hline
\end{tabular}

Yes

13

6

$y$

5 
Regarding Monitoring

Is The Composition of The

Atmosphere Changing?

All All All Non- Refereed Refereed

Papers Refereed Review Review Review Non-Review Papers Papers Papers Papers Papers

$\begin{array}{lcccccc}\text { Yes } & 118 & 64 & 50 & 68 & 24 & 40 \\ \text { No } & 2 & 2 & 0 & 2 & 0 & 2 \\ \text { Possibly } & 1 & 1 & 0 & 1 & 0 & 1\end{array}$

Regarding Monitoring

What Components are Changing?

$\begin{array}{cccccc}\text { All } & \text { All } & \text { All } & \text { Non- } & \text { Refereed } & \text { Refereed } \\ \text { Papers } & \text { Refereed } & \text { Review } & \text { Review } & \text { Review } & \text { Non-Review }\end{array}$ Papers Papers Papers Papers Papers

$\begin{array}{lcccccc}\begin{array}{l}\text { Carbon } \\ \text { Dioxide }\end{array} & 61 & 35 & 36 & 25 & 18 & 17 \\ \text { Methane } & 34 & 18 & 16 & 18 & 6 & 12 \\ \text { CFCs } & 35 & 15 & 17 & 18 & 7 & 8 \\ \text { Ozone } & 25 & 7 & 11 & 14 & 3 & 4 \\ \text { NOX/VOC } & 26 & 9 & 15 & 11 & 6 & 3 \\ \begin{array}{l}\text { Other } \\ \begin{array}{l}\text { Greenhouse } \\ \text { Gases }\end{array}\end{array} & 30 & 17 & 18 & 12 & 11 & 6\end{array}$

Regarding Monitoring

Has There Been An Increase In Global Temperature Over The Past Century?

$\begin{array}{cccccc}\text { All } & \text { All } & \text { All } & \text { Non- } & \begin{array}{c}\text { Refereed } \\ \text { Review }\end{array} & \begin{array}{c}\text { Refereed } \\ \text { Non-Review } \\ \text { Papers }\end{array} \\ \begin{array}{c}\text { Refereed } \\ \text { Papers }\end{array} & \begin{array}{c}\text { Review } \\ \text { Papers }\end{array} & \text { Rapers } & \text { Papers } & \text { Papers } & \text { Papers }\end{array}$

$\begin{array}{lcccccc}\text { Yes } & 37 & 17 & 23 & 14 & 8 & 9 \\ \text { No } & 2 & 2 & 1 & 1 & 1 & 1 \\ \text { Maybe } & 2 & 2 & 0 & 2 & 0 & 2\end{array}$

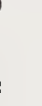

Regarding Monitoring

If A Global Temperature Increase Has Been

Observed Over The Past Century

Is It Statistically Significant? $\begin{array}{cccccc}\text { All } & \text { All } & \text { All } & \text { Non- } & \text { Refereed } & \text { Refereed } \\ \text { Papers } & \begin{array}{c}\text { Refereed } \\ \text { Papers }\end{array} & \begin{array}{c}\text { Review } \\ \text { Papers }\end{array} & \text { Rapers } & \text { Review } & \text { Non-Review } \\ \text { Papers } & \text { Papers }\end{array}$

Yes

2

$2 \quad 1 \quad 1$

$\begin{array}{ll}1 & 1 \\ 0 & 1\end{array}$

Regarding Monitoring

Has There Been An Increase In Temperature of A Region Over The Past Century?
All All All Non- Refereed Refereed Papers Refereed Review Review Review Non-Review \begin{tabular}{c} 
Papers Papers Papers Papers Papers \\
\hline
\end{tabular}

$\begin{array}{lllllll}\text { Yes } & 10 & 6 & 1 & 9 & 1 & 5 \\ \text { No } & 2 & 2 & 0 & 2 & 0 & 2 \\ \text { Maybe } & 0 & 0 & 0 & 0 & 0 & 0\end{array}$

If A Regional Temperature Increase Has Been Observed Over The Past Century

Is It Statistically Significant?

$$
\begin{array}{cccccc}
\text { All } & \text { All } & \text { All } & \text { Non- } & \text { Refereed } & \text { Refereed } \\
\text { Papers } & \begin{array}{c}
\text { Refereed } \\
\text { Review }
\end{array} & \text { Review } & \text { Review } & \text { Non-Review } \\
& \text { Papers } & \text { Papers } & \text { Papers } & \text { Papers } & \text { Papers }
\end{array}
$$

\begin{tabular}{lllllll}
\hline Yes & 1 & 1 & 1 & 0 & 1 & 0 \\
No & 3 & 1 & 0 & 3 & 0 & 1
\end{tabular}

No

-


Regarding Monitoring

If A Global Temperature Increase Has Been Observed Over The Past Decade Is It

Statistically Significant

$\begin{array}{cccccc}\text { All } & \text { All } & \text { All } & \text { Non- } & \text { Refereed } & \text { Refereed } \\ \text { Papers } & \begin{array}{c}\text { Refereed } \\ \text { Papers }\end{array} & \text { Review } & \text { Review } & \text { Review } & \text { Non-Review } \\ & \text { Papers } & \text { Papers } & \text { Papers }\end{array}$

Yes

No

$\begin{array}{llllll}2 & 2 & 0 & 2 & 0 & 2 \\ 4 & 1 & 1 & 3 & 0 & 1\end{array}$

Regarding Monitoring

Has There Been An Increase In Temperature Over A Region In The Past Decade?

$\begin{array}{cccccc}\text { All } & \text { All } & \text { All } & \text { Non- } & \text { Refereed } & \text { Refereed } \\ \text { Papers } & \begin{array}{c}\text { Refereed } \\ \text { Papers }\end{array} & \begin{array}{c}\text { Review } \\ \text { Papers }\end{array} & \text { Papers } & \begin{array}{c}\text { Review } \\ \text { Papers }\end{array} & \begin{array}{c}\text { Non-Review } \\ \text { Papers }\end{array}\end{array}$

$\begin{array}{lllllll}\text { Yes } & 7 & 5 & 2 & 5 & 2 & 3 \\ \text { No } & 1 & 1 & 0 & 1 & 0 & 1 \\ \text { Maybe } & 1 & 0 & 0 & 1 & 0 & 0\end{array}$

Regarding Monitoring

If A Regional Increase Has Been Observed Over The Past Decade Is It Statistically Significant?

$\begin{array}{cccccc}\text { All } & \text { All } & \text { All } & \text { Non- } & \text { Refereed } & \begin{array}{c}\text { Refereed } \\ \text { Papers }\end{array} \\ \begin{array}{c}\text { Refereed } \\ \text { Papers }\end{array} & \text { Review } & \text { Review } & \begin{array}{c}\text { Review } \\ \text { Non-Review } \\ \text { Papers }\end{array} & \text { Papers } & \text { Papers }\end{array}$

$\begin{array}{lllllll}\text { Yes } & 3 & 2 & 0 & 3 & 0 & 2 \\ \text { No } & 1 & 0 & 0 & 1 & 0 & 0\end{array}$

Regarding Monitoring

Over The Past Decade Has There Been

A Change in Global Precipitation?

$$
\begin{array}{cccccc}
\text { All } & \text { All } & \text { All } & \text { Non- } & \text { Refereed } & \begin{array}{c}
\text { Refereed } \\
\text { Papers }
\end{array} \\
& \begin{array}{c}
\text { Refereed } \\
\text { Papers }
\end{array} & \text { Review } & \text { Review } & \text { Review } & \text { Pon-Review } \\
\text { Papers } & \text { Papers }
\end{array}
$$

$\begin{array}{lllllll}\text { Yes } & 0 & 0 & 0 & 0 & 0 & 0 \\ \text { No } & 0 & 0 & 0 & 0 & 0 & 0 \\ \text { Maybe } & 0 & 0 & 0 & 0 & 0 & 0\end{array}$

Regarding Monitoring

Over The Past Decade Has There Been A Change In Precipiation Over A Region?

$$
\begin{array}{cccccc}
\text { All } & \text { All } & \text { All } & \text { Non- } & \text { Refereed } & \text { Refereed } \\
\text { Papers } & \begin{array}{c}
\text { Refereed } \\
\text { Papers }
\end{array} & \text { Rapew } & \text { Review } & \text { Review } & \text { Pon-Review } \\
\text { Papers } & \text { Papers }
\end{array}
$$

$\begin{array}{lllllll}\text { Yes } & 2 & 0 & 0 & 2 & 0 & 0 \\ \text { No } & 0 & 0 & 0 & 0 & 0 & 0 \\ \text { Maybe } & 2 & 1 & 0 & 2 & 0 & 1\end{array}$

\section{Regarding Monitoring}

Has There Been A Change In Weather Extremes Over The Globe In The Past Decade?

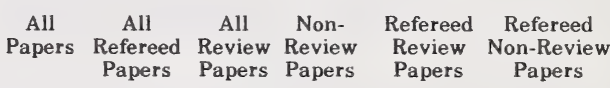

$\begin{array}{lllllll}\text { Yes } & 0 & 0 & 0 & 0 & 0 & 0 \\ \text { No } & 0 & 0 & 0 & 0 & 0 & 0 \\ \text { Maybe } & 0 & 0 & 0 & 0 & 0 & 0\end{array}$

\section{Regarding Monitoring \\ Has There Been A Change In Weather Extremes Over A Region In The Past Decade?}

$$
\begin{array}{cccccc}
\text { All } & \text { All } & \text { All } & \text { Non- } & \text { Refereed } & \text { Refereed } \\
\text { Papers } & \begin{array}{c}
\text { Refereed } \\
\text { Review }
\end{array} & \begin{array}{c}
\text { Review } \\
\text { Review } \\
\text { Non-Review } \\
\text { Papers }
\end{array} & \text { Papers } & \begin{array}{c}
\text { Papers } \\
\text { Papers }
\end{array}
\end{array}
$$

$\begin{array}{lllllll}\text { Yes } & 1 & 0 & 0 & 1 & 0 & 0 \\ \text { No } & 0 & 0 & 0 & 0 & 0 & 0 \\ \text { Maybe } & 0 & 0 & 0 & 0 & 0 & 0\end{array}$

Regarding Monitoring Cause of Observed Change In Temperature

$\begin{array}{lcccccc}\begin{array}{l}\text { Change in } \\ \text { atmosphere }\end{array} & 34 & 17 & 16 & 18 & 5 & 12 \\ \begin{array}{l}\text { Change in } \\ \text { solar activity }\end{array} & 3 & 3 & 2 & 1 & 2 & \text { I } \\ \begin{array}{l}\text { Urban } \\ \text { warming }\end{array} & 7 & 5 & 5 & 2 & 3 & 2 \\ \begin{array}{l}\text { Other } \\ \text { Otherm }\end{array} & 5 & 4 & 2 & 3 & 2 & 2\end{array}$


Regarding Impacts

Impact On World Of An Effective Doubling Of Greenhouse Gases

All All All Non- Refereed Refereed

Papers Refereed Review Review Review Non-Review Papers Papers Papers Papers Papers

$\begin{array}{lcccccc}\text { Positive } & 15 & 10 & 10 & 5 & 6 & 4 \\ \text { Negative } & 169 & 66 & 63 & 106 & 30 & 36 \\ \begin{array}{l}\text { Positive } \\ \text { \& negative }\end{array} & 61 & 34 & 26 & 35 & 15 & 19 \\ \text { Neutral } & 5 & 1 & 3 & 2 & 0 & 1 \\ \text { Unknown } & 19 & 5 & 9 & 10 & 3 & 2\end{array}$

Regarding Impacts

Impact On Canada Of An Effective Doubling Of Greenhouse Gases
Regarding Impacts

Impact On Alberta Of An Effective Doubling Of Greenhouse Gases

$\begin{array}{cccccc}\text { All } & \text { All } & \text { All } & \text { Non- } & \text { Refereed } & \text { Refereed } \\ \text { Papers } & \text { Refereed } & \text { Review } & \text { Review } \\ \text { Papers } & \text { Papersiew } & \text { Papers } & \text { Papers } & \text { Papeview } \\ & & & \text { Papers }\end{array}$

$\begin{array}{lllllll}\text { Positive } & 1 & 0 & 0 & 1 & 0 & 0 \\ \text { Negative } & 3 & 2 & 0 & 3 & 0 & 2 \\ \begin{array}{l}\text { Positive } \\ \text { \& negative }\end{array} & 3 & 1 & 0 & 3 & 0 & 1 \\ \text { Neutral } & 0 & 0 & 0 & 0 & 0 & 0 \\ \text { Unknown } & 1 & 0 & 0 & 1 & 0 & 0\end{array}$

Regarding Impacts

Impact On Agriculture Of An Effective Doubling Of Greenhouse Gases

$\begin{array}{cccccc}\text { All } & \text { All } & \text { All } & \text { Non- } & \text { Refereed } & \text { Refereed } \\ \text { Papers } & \begin{array}{c}\text { Refereed } \\ \text { Papers }\end{array} & \begin{array}{c}\text { Review } \\ \text { Papers }\end{array} & \text { Papers } & \text { Peview } & \text { Pon-Review } \\ & \text { Papers } & \text { Papers }\end{array}$

$\begin{array}{lrrrrrr}\text { Positive } & 17 & 7 & 2 & 15 & 2 & 5 \\ \text { Negative } & 27 & 8 & 5 & 22 & 4 & 4 \\ \begin{array}{l}\text { Positive } \\ \text { \& negative }\end{array} & 44 & 11 & 10 & 34 & 3 & 8 \\ \text { Neutral } & 4 & 2 & 0 & 4 & 0 & 2 \\ \text { Unknown } & 6 & 2 & 0 & 6 & 0 & 2\end{array}$

Regarding Impacts

Impact On Prairies Of An Effective Doubling Of Greenhouse Gases
All All All Non- Refereed Refereed

Papers Refereed Review Review Review Non-Review Papers Papers Papers Papers Papers

$\begin{array}{lcccccc}\text { Positive } & 8 & 5 & 5 & 3 & 3 & 2 \\ \text { Negative } & 19 & 7 & 10 & 9 & 5 & 2 \\ \begin{array}{l}\text { Positive } \\ \& \text { negative }\end{array} & 45 & 22 & 17 & 28 & 10 & 12 \\ \text { Neutral } & 2 & 2 & 0 & 2 & 0 & 2 \\ \text { Unknown } & 5 & 1 & 2 & 3 & 1 & 0\end{array}$

Regarding Impacts

Impact On Forestry Of An Effective Doubling Of Greenhouse Gases
All All All Non- Refereed Refereed

Papers Refereed Review Review Review Non-Review Papers Papers Papers Papers Papers

$\begin{array}{lcccccc}\text { Positive } & 1 & 1 & 0 & 1 & 0 & 1 \\ \text { Negative } & 6 & 4 & 2 & 4 & 2 & 2 \\ \begin{array}{l}\text { Positive } \\ \text { \& negative }\end{array} & 14 & 2 & 4 & 10 & 0 & 2 \\ \text { Neutral } & 0 & 0 & 0 & 0 & 0 & 0 \\ \text { Unknown } & 0 & 0 & 0 & 0 & 0 & 0\end{array}$

All All All Non- Refereed Refereed

Papers Refereed Review Review Review Non-Review Papers Papers Papers Papers Papers

$\begin{array}{lcccccc}\text { Positive } & 6 & 5 & 2 & 4 & 1 & 4 \\ \text { Negative } & 39 & 14 & 10 & 29 & 5 & 9 \\ \begin{array}{l}\text { Positive } \\ \text { \& negative }\end{array} & 13 & 7 & 2 & 11 & 2 & 5 \\ \text { Neutral } & 4 & 1 & 1 & 3 & 0 & 1 \\ \text { Unknown } & 6 & 3 & 1 & 5 & 1 & 2\end{array}$


Regarding Impacts

Impact On The Energy Industry Of An Effective Doubling Of Greenhouse Gases

All All All Non- Refereed Refereed

Papers Refereed Review Review Review Non-Review

Papers Papers Papers Papers Papers

$\begin{array}{lllllll}\text { Positive } & 7 & 3 & 1 & 6 & 1 & 2 \\ \text { Negative } & 9 & 5 & 1 & 8 & 0 & 5 \\ \begin{array}{l}\text { Positive } \\ \text { \& negative }\end{array} & 9 & 2 & 1 & 8 & 0 & 2 \\ \text { Neutral } & 0 & 0 & 0 & 0 & 0 & 0 \\ \text { Unknown } & 2 & 0 & 1 & 1 & 0 & 0\end{array}$

Regarding Impacts

Impact On Tourism Of An Effective Doubling of Greenhouse Gases

$\begin{array}{lllllll}\text { Positive } & 3 & 1 & 1 & 2 & 1 & 0 \\ \text { Negative } & 6 & 3 & 2 & 4 & 1 & 2 \\ \begin{array}{l}\text { Positive } \\ \text { \& negative }\end{array} & 9 & 1 & 4 & 5 & 1 & 0 \\ \text { Neutral } & 1 & 0 & 1 & 0 & 0 & 0 \\ \text { Unknown } & 1 & 0 & 0 & 1 & 0 & 0\end{array}$

Regarding Impacts

Impact On The Economy Of An Effective Doubling Of Greenhouse Gases

$\begin{array}{cccccc}\text { All } & \text { All } & \text { All } & \text { Non- } & \text { Refereed } & \text { Refereed } \\ \text { Papers } & \begin{array}{c}\text { Refereed } \\ \text { Papers }\end{array} & \text { Review } & \text { Review } & \text { Review } & \text { Non-Review } \\ \text { Papers } & \text { Papers } & \text { Papers }\end{array}$

$\begin{array}{lcccccc}\text { Positive } & 2 & 0 & 0 & 2 & 0 & 0 \\ \text { Negative } & 12 & 4 & 4 & 8 & 2 & 2 \\ \begin{array}{l}\text { Positive } \\ \text { \& negative }\end{array} & 9 & 2 & 4 & 5 & 2 & 0 \\ \text { Neutral } & 0 & 0 & 0 & 0 & 0 & 0 \\ \text { Unknown } & 2 & 0 & 0 & 2 & 0 & 0\end{array}$

\section{Regarding Impacts \\ Impact On Employment Of An Effective Doubling Of Greenhouse Gases}

$\begin{array}{cccccc}\text { All } & \text { All } & \text { All } & \text { Non- } & \text { Refereed } & \text { Refereed } \\ \text { Papers } & \text { Refereed } & \text { Review } & \text { Review } & \text { Review } & \text { Non-Review } \\ \text { Papers } & \text { Papers } & \text { Papers } & \text { Papers } & \text { Papers }\end{array}$

$\begin{array}{lllllll}\text { Positive } & \text { I } & 1 & 0 & 1 & 0 & 1 \\ \text { Negative } & 2 & 0 & 0 & 2 & 0 & 0 \\ \begin{array}{l}\text { Positive } \\ \text { \& negative }\end{array} & 1 & 0 & 0 & 1 & 0 & 0 \\ \text { Neutral } & 0 & 0 & 0 & 0 & 0 & 0 \\ \text { Unknown } & 0 & 0 & 0 & 0 & 0 & 0\end{array}$

Regarding Impacts

Impact On Fisheries Of An Effective Doubling Of Greenhouse Gases

$\begin{array}{lllllll}\text { Positive } & 1 & 0 & 0 & 1 & 0 & 0 \\ \text { Negative } & 3 & 1 & 1 & 2 & 1 & 0 \\ \begin{array}{l}\text { Positive } \\ \text { \& negative }\end{array} & 7 & 3 & 2 & 5 & 1 & 2 \\ \text { Neutral } & 0 & 0 & 0 & 0 & 0 & 0 \\ \text { Unknown } & 3 & 0 & 2 & 1 & 0 & 0\end{array}$

\section{Regarding Impacts \\ Impact On Coastlines Of An Effective Doubling Of Greenhouse Gases}

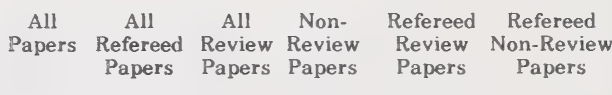

$\begin{array}{lcccccc}\text { Positive } & 0 & 0 & 0 & 0 & 0 & 0 \\ \text { Negative } & 41 & 20 & 18 & 23 & 11 & 9 \\ \begin{array}{l}\text { Positive } \\ \text { \& negative }\end{array} & 1 & 1 & 0 & 1 & 0 & 1 \\ \text { Neutral } & 0 & 0 & 0 & 0 & 0 & 0 \\ \text { Unknown } & 0 & 0 & 0 & 0 & 0 & 0\end{array}$


Regarding Impacts

Impact On Health Of An Effective Doubling Of Greenhouse Gases

$\begin{array}{lcccccc}\text { Positive } & 0 & 0 & 0 & 0 & 0 & 0 \\ \text { Negative } & 15 & 5 & 7 & 8 & 4 & 1 \\ \begin{array}{l}\text { Positive } \\ \text { \& negative }\end{array} & 1 & 0 & 1 & 0 & 0 & 0 \\ \text { Neutral } & 0 & 0 & 0 & 0 & 0 & 0 \\ \text { Unknown } & 1 & 0 & 1 & 0 & 0 & 0\end{array}$

Unknown

Regarding Impacts

Impact On Other Systems Of An Effective Doubling Of Greenhouse Gases

All All All Non- Refereed Refereed

Papers Refereed Review Review Review Non-Review Papers Papers Papers Papers Papers

$\begin{array}{lcccccc}\text { Positive } & 3 & 1 & 1 & 2 & 1 & 0 \\ \text { Negative } & 45 & 14 & 9 & 36 & 3 & 11 \\ \begin{array}{l}\text { Positive } \\ \text { \& negative }\end{array} & 19 & 8 & 5 & 14 & 2 & 6 \\ \text { Neutral } & 1 & 0 & 1 & 0 & 0 & 0 \\ \text { Unknown } & 6 & 3 & 2 & 4 & 1 & 2\end{array}$

Regarding Strategies/Solutions

Impact On Food Supplies Of An Effective Doubling Of Greenhouse Gases

$\begin{array}{cccccc}\text { All } & \text { All } & \text { All } & \text { Non- } & \text { Refereed } & \text { Refereed } \\ \text { Papers } & \begin{array}{c}\text { Refereed } \\ \text { Papers }\end{array} & \text { Papers } & \text { Review } & \text { Papers } & \text { Review } \\ \text { Papers } & \text { Non-Review } \\ \text { Papers }\end{array}$

$\begin{array}{lcccccc}\text { Positive } & 3 & 2 & 2 & 1 & 1 & 1 \\ \text { Negative } & 10 & 3 & 6 & 4 & 2 & 1 \\ \begin{array}{l}\text { Positive } \\ \text { \& negative }\end{array} & 7 & 1 & 4 & 3 & 0 & 1 \\ \text { Neutral } & 1 & 0 & 0 & 1 & 0 & 0 \\ \text { Unknown } & 0 & 0 & 0 & 0 & 0 & 0\end{array}$

\section{Regarding Impacts}

Impact On Global Security Of An Effective Doubling Of Greenhouse Gases

$\begin{array}{cccccc}\text { All } & \text { All } & \text { All } & \text { Non- } & \begin{array}{c}\text { Refereed } \\ \text { Review }\end{array} & \begin{array}{c}\text { Refereed } \\ \text { Non-Review } \\ \text { Papers }\end{array} \\ \begin{array}{c}\text { Refereed } \\ \text { Papers }\end{array} & \begin{array}{c}\text { Review } \\ \text { Papers }\end{array} & \text { Papers } & \begin{array}{c}\text { Reviers } \\ \text { Papers }\end{array} & \text { Papers }\end{array}$

$\begin{array}{lllllll}\text { Positive } & 0 & 0 & 0 & 0 & 0 & 0 \\ \text { Negative } & 4 & 4 & 2 & 2 & 2 & 2 \\ \begin{array}{l}\text { Positive } \\ \text { \& negative }\end{array} & 1 & 1 & 0 & 1 & 0 & 1 \\ \text { Neutral } & 0 & 0 & 0 & 0 & 0 & 0 \\ \text { Unknown } & 0 & 0 & 0 & 0 & 0 & 0\end{array}$

\section{Sectors For Which Adaptation Strategies Are Suggested}

$\begin{array}{cccccc}\text { All } & \text { All } & \text { All - } & \text { Non- } & \text { Refereed } & \text { Refereed } \\ \text { Papers } & \text { Refereed } & \text { Review } & \text { Review } & \text { Review } & \text { Non-Revie } \\ & \text { Papers } & \text { Papers } & \text { Papers } & \text { Papers } & \text { Papers }\end{array}$

\begin{tabular}{|c|c|c|c|c|c|}
\hline Agriculture & 42 & 15 & 17 & 25 & 8 \\
\hline Forestry & 15 & 7 & 2 & 13 & 2 \\
\hline $\begin{array}{l}\text { Water } \\
\text { management }\end{array}$ & 44 & 13 & 17 & 27 & 7 \\
\hline Tourism & 5 & 2 & 1 & 4 & 1 \\
\hline $\begin{array}{l}\text { Coastal } \\
\text { policies }\end{array}$ & 20 & 9 & 11 & 9 & 7 \\
\hline Other & 18 & 3 & 7 & 11 & 1 \\
\hline
\end{tabular}

Regarding Strategies/Solutions

Emissions For Which Limitation Strategies Are Suggested

$\begin{array}{cccccc}\text { All } & \text { All } & \text { All } & \text { Non- } & \text { Refereed } & \text { Refereed } \\ \text { Papers } & \text { Refereed } & \text { Review } & \text { Review } \\ \text { Papers } & \text { Papers } & \text { Papers } & \text { Papers } & \begin{array}{c}\text { Non-Review } \\ \text { Papers }\end{array} \\ & & \end{array}$

\begin{tabular}{|c|c|c|c|c|c|}
\hline $\begin{array}{l}\text { Carbon } \\
\text { dioxide }\end{array}$ & 76 & 13 & 20 & 56 & 7 \\
\hline Methane & 10 & 1 & 2 & 8 & 0 \\
\hline CFCs & 45 & 14 & 19 & 26 & 8 \\
\hline Ozone & 6 & 0 & 2 & 4 & 0 \\
\hline NOX/VOC & 10 & 5 & 4 & 6 & 1 \\
\hline Other & 7 & 4 & 3 & 4 & 2 \\
\hline $\begin{array}{l}\text { Greenhouse } \\
\text { gases }\end{array}$ & 36 & 7 & 16 & 20 & 6 \\
\hline
\end{tabular}


Regarding Strategies/Solutions Technological Solutions Suggested
All All
All All Non- Refereed Refereed
Papers Refereed Review Review Review Non-Review
Papers Papers Papers Papers Papers

\begin{tabular}{|c|c|c|c|c|c|}
\hline $\begin{array}{l}\text { Energy } \\
\text { efficiency }\end{array}$ & 109 & 20 & 32 & 77 & 8 \\
\hline $\begin{array}{l}\text { Fuel } \\
\text { substitution }\end{array}$ & 94 & 21 & 27 & 67 & 8 \\
\hline $\begin{array}{l}\text { Carbon } \\
\text { dioxide caput }\end{array}$ & $\begin{array}{c}22 \\
\text { ture }\end{array}$ & 2 & 1 & 21 & 0 \\
\hline $\begin{array}{l}\text { Clean } \\
\text { combustion }\end{array}$ & 19 & 3 & 1 & 18 & 0 \\
\hline $\begin{array}{l}\text { Af/re } \\
\text { forestation }\end{array}$ & 47 & 16 & 18 & 29 & 8 \\
\hline Landfills & 0 & 0 & 0 & 0 & 0 \\
\hline $\begin{array}{l}\text { Climate } \\
\text { modification }\end{array}$ & 1 & 1 & 1 & 0 & 1 \\
\hline Other & 32 & 5 & 7 & 25 & 3 \\
\hline
\end{tabular}



